\title{
DESEMPENHO DE DUAS GRAMÍNEAS FORRAGEIRAS TROPICAIS TOLERANTES AO ESTRESSE HÍDRICO POR ALAGAMENTO EM DOIS SOLOS GLEI HÚMICOS
}

\author{
Michelle NAZARÉ XAVIER DA Costa
}

\begin{abstract}
Tese apresentada à Escola Superior de Agricultura
“Luiz de Queiroz”, Universidade de São Paulo, para obtenção do título de Doutor em Agronomia, Área de Concentração: Ciência Animal e Pastagens.
\end{abstract}

P I R A C I C A B A

Estado de São Paulo - Brasil

Fevereiro - 2004 


\title{
DESEMPENHO DE DUAS GRAMÍNEAS FORRAGEIRAS TROPICAIS TOLERANTES AO ESTRESSE HÍDRICO POR ALAGAMENTO EM DOIS SOLOS GLEI HÚMICOS
}

\author{
Michelle NAZARÉ XAVier da Costa \\ Engenheira Agrônoma
}

Orientador: Prof. Dr. HERBERT BARBOSA DE MATTOS

\author{
Tese apresentada à Escola Superior de Agricultura \\ “Luiz de Queiroz”, Universidade de São Paulo, para \\ obtenção do título de Doutor em Agronomia, Área de \\ Concentração: Ciência Animal e Pastagens.
}

P I R A C I C A B A

Estado de São Paulo - Brasil

Fevereiro - 2004 

Dados Internacionais de Catalogação na Publicação (CIP)
DIVISÃO DE BIBLIOTECA E DOCUMENTAÇÃO - ESALQ/USP

Costa, Michelle Nazaré Xavier da

Desempenho de duas gramíneas forrageiras tropicais tolerantes ao estresse hídrico por alagamento em dois solos glei húmicos / Michelle Nazaré Xavier da Costa. - -

Piracicaba, 2004.

89 p. : il.

Tese (doutorado) - Escola Superior de Agricultura Luiz de Queiroz, 2004.

Bibliografia.

1. Estresse hídrico 2. Fisiologia vegetal 3. Gramínea forrageira tropical 4. Inundação 5. Propriedades físico-química 6. Solos I. Título

CDD 633.2

"Permitida a cópia total ou parcial deste documento, desde que citada a fonte - O autor" 
Aos meus pais Olívio e Nazareth, pelo exemplo de educação, dedicação e amor aos filhos, principalmente pelo incansável incentivo para realização desse trabalho,

Aos meus irmãos Michell e Marcus Vinícius, a Marco Aurélio e meus familiares pelo apoio, carinho e compreensão em todos os momentos,

DEDICO

A Juliana, Lílian, Lúcia e Rosângela, pelos momentos de solidariedade, companheirismo e alegria, pela convivência na certeza de que sempre seremos eternas amigas, 


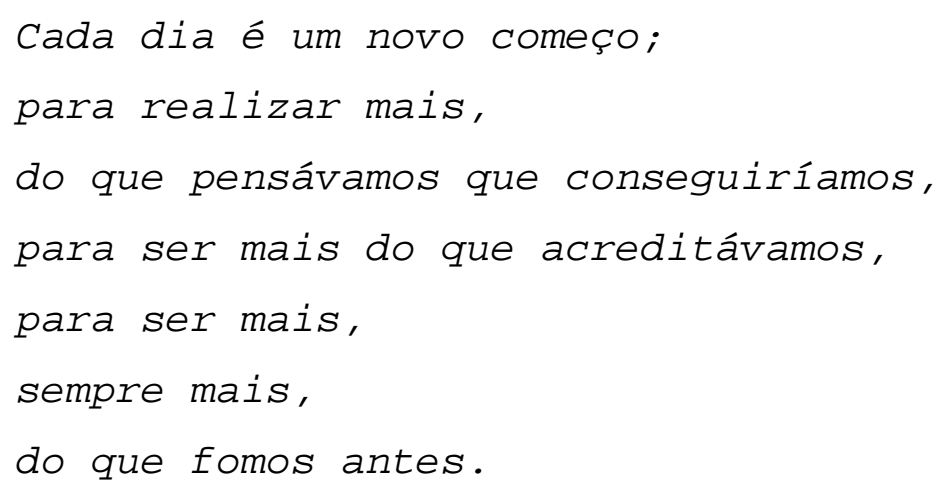

(Texto citado na minha dissertação de mestrado apresentada em janeiro de 2000)

Comecei tudo novamente; realizei mais,

mais até do que pensei, consegui e acreditei, tentei ser mais, muito mais do que fui antes, e hoje, sei que o amanhã será muito melhor. 


\section{AGRADECIMENTOS}

* A Deus pela proteção, luz, força e ajudar-me a superar as adversidades encontradas durante esta etapa de minha vida.

* À Escola Superior de Agricultura “Luiz de Queiroz” e Curso de Pós-Graduação em Ciência Animal e Pastagens por mais uma oportunidade de treinamento.

* Ao Prof. dr. Herbert B. De Mattos, mais uma vez pelo incentivo, atenção, confiança e amizade, ao me permitir caminhar e escolher o percurso trilhado.

* À FAPESP, pela concessão da bolsa de estudos, e suporte financeiro disponibilizado para a execução deste trabalho.

* Ao Prof. DR. RicARdo F. DE Oliveira, pelo incentivo, apoio e confiança em disponibilizar o Laboratório de Plantas Cultivadas sob Condições de Estresse à livre utilização para o desenvolvimento deste projeto.

* Ao pesquisador da EMBRAPA/CPATU, Dr. MoACyr B. DiAs FILHO, pela eterna paciência e disponibilidade em ajudar no andamento e discussão do trabalho.

* Ao Prof. Dr. Ciniro Costa/UnESP/Botucatu pela disponibilidade em contribuir para realização deste trabalho.

* Aos Profs. Drs. LÁzaro Peres e Ricardo A. De Azevedo pela ajuda e auxílio no aperfeiçoamento e execução da metodologia de análise enzimática.

* A Dra. Salete Gaziola pela amizade, treinamento e auxílio na execução das análises enzimáticas.

* Ao Prof. Dr. Pablo V. Torrado pelo apoio e cessão de instrumentos de avaliação de campo.

* Ao Prof. Dr. André AlCARde pelas orientações nas análises laboratoriais prévias realizadas para estimativa de etanol.

* Ao Prof. Dr. Carlos Guilherme S. Pedreira pela valiosa contribuição de seus ensinamentos e cessão de equipamentos para otimizar a execução do trabalho. 
* Ao Prof. Dr. Sila Carneiro da Silva pelo apoio e auxílio nas análises estatísticas.

* Ao PROF. DR. CÉSAR DE LIMA / FZEA pela enorme contribuição nas análises estatísticas do trabalho.

* Ao Prof. Dr. Francisco ANTÔNIO MonteIRo pelas sugestões na discussão do trabalho.

* Ao Prof. DR. Quirino Carmello e funcionárias do Laboratório de Solos e Nutrição de Plantas pelas análises laboratoriais.

* Ao funcionário CARlos CÉSAR Alves do Laboratório de Bromatologia, pela amizade e colaboração nas análises laboratoriais.

* Ao Eng ${ }^{0}$. Agr ${ }^{0}$ Dr. Luis Fernando CAMPECHE, pela inestimável amizade e importante auxílio no planejamento e execução do trabalho.

* Aos amigos Felipe Tonato, Alexandre Mello, luiz F. Martins, Rafael Vasconcelos, Mauro Santos, Gustavo Maia, Miriam Ferraz, Leonardo Moreno, Luciana Gerdes, Daniele loures, Raul Almeida, Patrícia Sarmento, Fábio Campos, Gustavo Braga, Daniel de Paula, Míriam Costa, Henrique Medeiros, Sérgio Fernandes, Maria Del Carmem, Lyssa Otani e Daniel Rodrigues pela amizade, incentivo e ajuda essencial nos momentos mais difíceis durante a realização deste trabalho.

* Aos funcionários Francisco "Pequeno" e FranCISCO "Tirolês” do Laboratório de Plantas Cultivadas sob Condições de Estresse pelo auxílio durante a condução do trabalho.

* Ao Zootec. Getúlio F.B. Guimarães e SR. Getúlio Guimarães pela amizade, hospitalidade e imprescindível apoio logístico em Salvaterra - PA, nas coletas de campo.

* Aos demais professores da ESALQ pelos ensinamentos adquiridos e exemplo profissional.

* Aos colegas do curso de pós-graduação, pela amizade e troca de conhecimentos e experiências.

* À Giovana e Cleide pela amizade e auxílios prestados junto as secretarias do curso e departamento de Zootecnia.

* Aos funcionários da biblioteca/ ESALQ/USP e xerox do CALQ pela atenção durante toda pós-graduação.

* As famílias Pittol Firme - ES e Antunes Galvão - SP pela amizade, apoio e acolhida como mais um membro da família.

* As Repúblicas Vira Latas, Zona Rural, Uspeão, Caminho do Céu, Deus Quis e Blue House, pelo convívio e as novas amizades que sempre ajudaram amenizar a ausência da família. 


\section{SUMÁRIO}

Página

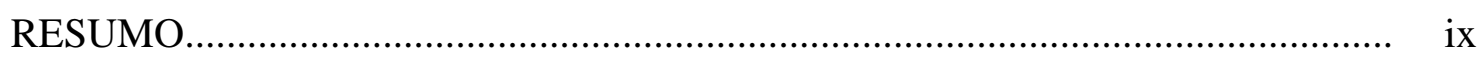

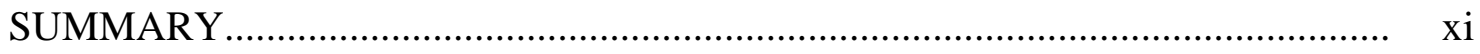

1 INTRODUÇÃ

2 REVISÃO DE LITERATURA.................................................................. 3

2.1 Solos sob inundação............................................................................. 3

2.2 Pontencial de oxirredução e pH em solos inundados.......................................... 4

2.3 Os nutrientes, formas, disponibilidade e toxidez em solos inundados................. 6

2.4 Fisiologia de plantas sob excesso hídrico....................................................... 8

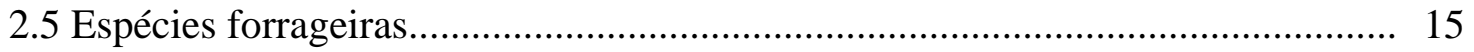

2.5.1 Brachiaria mutica (Forsk) Stapf............................................................... 15

2.5.2 Echinochloa polystachya (H.B.K.) Hitch.................................................... 16

2.6 Experimentos avaliando excesso hídrico..................................................... 17

3 MATERIAL E MÉTODOS....................................................................... 21

3.1 Localização do experimento...................................................................... 21

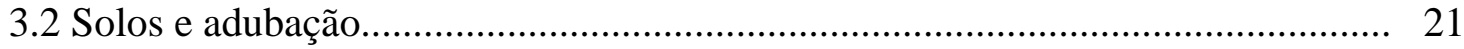

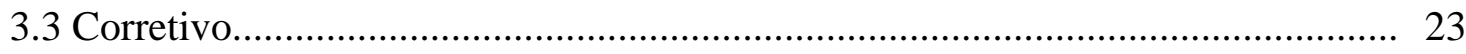

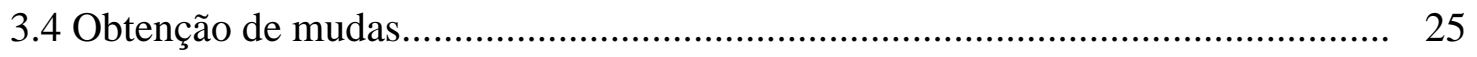

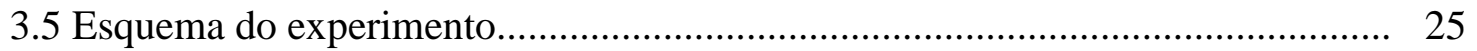

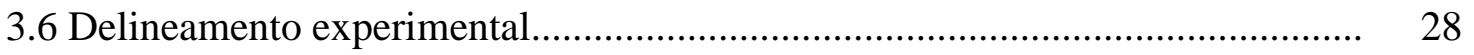

3.6.1 Preparação e plantio................................................................................. 29

3.6.2 Condução do experimento..................................................................... 30

3.6.3 Parâmetros analisados............................................................................. 32 
3.7 Análises estatísticas........................................................................................... 39

4 RESULTADOS E DISCUSSÃO............................................................. 40

4.1 Características morfofisiológicas....................................................................... 40

4.1.1 Fotossíntese........................................................................................ 40

4.1.2 Atividade da álcool desidrogenase (ADH),................................................... 44

4.1.3 Número de perfilhos totais............................................................................ 45

4.1.4 Produção de matéria seca da parte aérea e área foliar.......................................... 47

4.1.5 Relação folha:haste............................................................................................. 53

4.1.6 Produção de matéria seca de raiz................................................................... 55

4.2 Composição química......................................................................................... 57

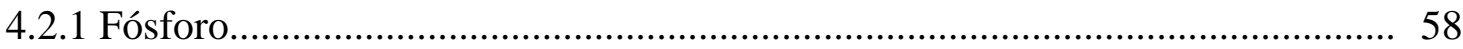

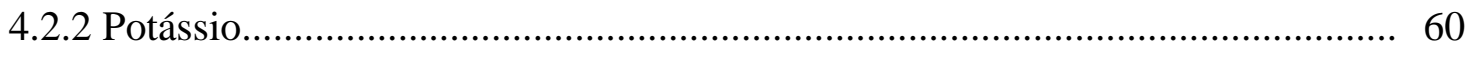

4.2.3 Cálcio....................................................................................................... 61

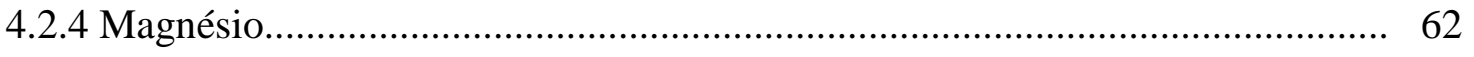

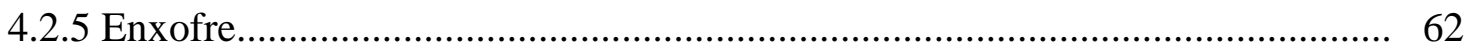

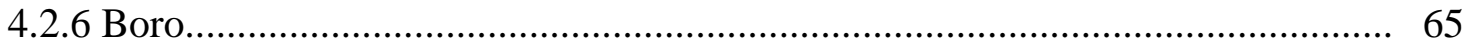

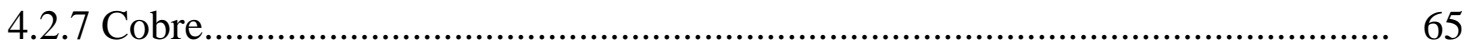

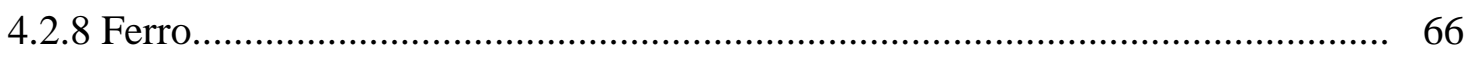

4.2.9 Manganês.......................................................................................................... 67

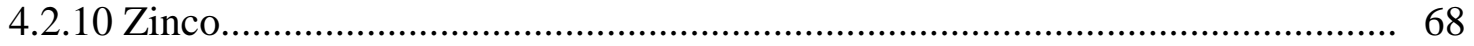

4.3 Composição químico - bromatológica.................................................................... 68

4.3.1 Proteína bruta............................................................................................ 69

4.3.2 FDN, FDA e lignina.............................................................................. 70

4.4 Características físico-químicas dos solos sob alagamento.................................... 73

4.4.1 Temperatura do solo..................................................................................... 73

4.4.2 pH e Eh dos solos alagados.......................................................................... 75

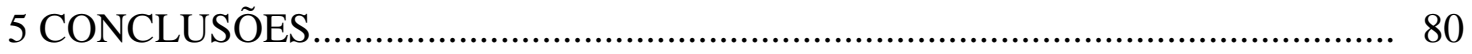

REFERÊNCIAS BIBLIOGRÁFICAS............................................................ 81 


\title{
DESEMPENHO DE DUAS GRAMÍNEAS FORRAGEIRAS TROPICAIS TOLERANTES AO ESTRESSE HÍDRICO POR ALAGAMENTO EM DOIS SOLOS GLEI HÚMICOS
}

\author{
Autora: MICHELLE NAZARÉ XAVIER DA COSTA \\ Orientador: Prof. Dr. HERBERT BARBOSA DE MATTOS
}

\section{RESUMO}

A falta de informações relacionadas às respostas das plantas ao alagamento tem sido alvo de inúmeras pesquisas no mundo todo. Essas informações tornam-se mais escassas quando relacionadas à gramíneas forrageiras de áreas inundáveis. A maioria dessas espécies pertence a ecossistemas de pastagens nativas de áreas inundáveis, os quais podem ter papel importante no desenvolvimento da pecuária brasileira, devido ao potencial de produção de forragem para alimentação de rebanhos. Diante do exposto, os objetivos do trabalho foram avaliar o desempenho da Brachiaria mutica (Forsk) Stapf $e$ Echinochloa polystachya (H.B.K) Hitch.] tolerantes ao excesso hídrico por alagamento, cultivadas em dois Plintossolos (glei húmicos), submetidos a duas condições de umidade: alagamento e capacidade de campo, por meio de fotossíntese, condutância estomática, atividade da álcool desidrogenase, produção de matéria seca da parte aérea e raiz, composição química e qualidade das forragens, além de verificar alterações nas características físico-químicas dos solos sob excesso hídrico que pudessem influenciar no desempenho das espécies. O experimento foi conduzido em casa de vegetação do departamento de Ciências Biológicas/ESALQ/USP, em Piracicaba - SP. Os tratamentos 
foram a combinação entre capins $\mathrm{x}$ condições de umidade $\mathrm{x}$ tipos de solo em um delineamento experimental de parcelas subdivididas com arranjo fatorial 2 x 2 nas subparcelas e como repetições, quatro blocos casualizados. Consideraram-se como parcelas, condições de umidade (alagamento e capacidade de campo), e subparcelas interações entre dois capins e dois solos, totalizando 32 unidades experimentais.Foram realizados três cortes no durante o experimento, sendo apenas dois considerados para cômputo dos resultados. Os resultados obtidos demonstraram que as gramíneas forrageiras respondem diferentemente em função do alagamento e dos tipos de solos em relação as variáveis estudadas, onde a E. polystachya apresenta melhor capacidade de adaptação em relação a $B$. mutica. A fotossíntese líquida e a condutância estomática dos capins B. mutica e E. polystachya não foram afetadas sob alagamento, essa resposta foi atribuída à ativação dos mecanismos de adaptações morfológicos, metabólicos e anatômicos das espécies, como a formação de raízes adventícias, o aumento na produção de matéria seca de hastes e raiz. Contudo, apesar da adaptação dos capins ao ambiente anóxico verificou-se reduções na área foliar, nas produções de matéria seca de lâmina foliar e total, relação folha:haste, no número de perfilhos, causando desequilíbrio na alocação da biomassa entre parte aérea e o sistema radicular. Os capins apresentaram alterações na composição química com o alagamento, reduzindo teores dos nutrientes para ambas as espécies, com exceção do fósforo e ferro sem, no entanto comprometer o estado nutricional das espécies. A composição químico-bromatológica também foi afetada pelo alagamento e tipo de solo gerando aumentos nos teores de fibra e redução nas concentrações de lignina. As mudanças ocorridas nas características morfofisiológicas, na produção, composição nutricional e bromatológica nas gramíneas forrageiras estão associadas às alterações nas propriedades físico-química dos solos causadas pelo déficit de oxigênio, transformando os solos em um ambiente reduzido. 


\title{
BEHAVIOR OF TWO TOLERANT TROPICAL FORAGE GRASSES TO FLOODING IN TWO GLEI HUMIC SOILS
}

\author{
Author: MICHELLE NAZARÉ XAVIER DA COSTA \\ Adviser: Prof. Dr. HERBERT BARBOSA DE MATTOS
}

\section{SUMMARY}

The lack of information related on responses of plants to flooding has been the motivation of many research woks throughout the world. This information, become even scarcer when related to tropical forage tropical grasses of areas to flooding.The majority of those grasses characteristic of those areas, which could play an important role in the development of the livestock industry in Brazil, due to their potential of forage production. The objectives of this study were to evaluate the acting of the Brachiaria mutica (Forsk) Stapf and Echinochloa polystachya (H.B.K) Hitch.] the flooding tolerance, cultivated in two Plintossolos (gley), by subjecting the plants to two humidity conditions: flooding and field capacity and measuring photosynthesis, stomatal conductance, activity of the alcohol dehidrogenase activity, shoot and root dry matter productions, chemical composition and quality. Also it, was studying the influence of changes in the physiochemical characteristics of the soils under flood on the behavior of these species. The experiment was carried out in a greenhouse of the Biology Science department at USP-ESALQ in Piracicaba - SP. The treatments were the combination among grasses; humidity conditions and soil types in a split plot design with a factorial arrangement of $2 \times 2$ and as repetitions four randomized blocks. The plot was considered 
as the humidity conditions (flooding and field capacity), and the split plot were the interactions between the two grasses and the two soil types, totaling 32 experimental units. Three harvests were made during the experiment, though, only the two were considered. Net photosynthesis and stomatal conductance were not affected by flooding, which was attributed to the activation of the morphologic, metabolic and anatomical mechanisms of adaptations of these species. Adventitious roots formation, dry matter production of stems and roots were stimulated by flooding, however, leaf area, leaf and total dry mass productions, leaf:stem ratio and the number of tillers were reduced by flooding, causing detrimental effects in the biomass allocation between shoot and root. Flooding caused significant changes in the mineral composition reducing nutrients contents, except for phosphorus and iron, however, without compromising nutritional status of both species. The chemical composition of the species was also affected by flooding which caused an increase in the fiber contents and a reduction in lignin concentrations. The changes in the morphological characteristics, production, mineral and chemical composition in the tropical forage grasses were associated to the alterations in the physiochemical properties of the soils caused by the lack of oxygen, transforming the soils in a reduced environment. 


\section{INTRODUÇÃO}

As pastagens nativas de áreas inundáveis representam um papel muito importante no desenvolvimento da pecuária no território brasileiro, devido ao seu potencial de produção de forragem para alimentação de rebanhos.

De modo geral, essas áreas são submetidas às inundações periódicas pela água das chuvas ou pelos rios que cruzam a região.

Sabe-se que a composição botânica, a produção e a qualidade dessas pastagens, são fortemente influenciadas por vários fatores, entre eles, o hidrológico. Sob esse ponto de vista, as pastagens nativas da região do trópico úmido brasileiro podem ser classificadas como pastagens nativas de áreas inundáveis de solos aluviais e pastagens nativas de savanas mal drenadas.

O ecossistema das pastagens nativas de solos aluviais é formado principalmente nas áreas de várzea que ocorrem em associação com as águas barrentas e turvas do rio Amazonas e seus afluentes, compreendendo regiões tais como: baixo e médio Amazonas, na Ilha de Marajó e áreas do Amapá, que sofrem influência das águas do estuário do rio Amazonas. Tais pastagens são regionalmente chamadas de "pastagens de várzea”.

As savanas mal drenadas possuem características similares as de terra inundável porém, associadas a inundações por rios cujas águas não são ricas como os rios de água barrenta. Essas são as áreas da região leste da Ilha de Marajó, zonas da baixada Maranhense, Ilha do Bananal e os campos inundáveis do Pantanal.

Dentro da composição botânica existente no ecossistema de pastagem nativa, as gramíneas são as plantas mais importantes e predominantes na associação, entre elas as de interesse forrageiro. A maioria dessas gramíneas encontradas são consideradas adaptadas, pelo fato de suportarem longos períodos de alagamento (5 ou mais meses). 
Durante o período de alagamento estas plantas têm a capacidade de produzir folhas sobre a superfície da água, ou até permanecerem dormentes quando submersas, possuindo alto potencial de produção e qualidade superiores em relação as pastagens nativas de terra firme.

As pastagens nativas sujeitas às inundações têm grande relevância e potencial produtivo no Brasil, ocupando na Amazônia áreas de até 10 milhões de hectares e, no Pantanal, onde a maior parte dos seus quatro milhões de hectares destinados a pastagens se alagam na época das cheias (IBGE, 1996).

Apesar da importância que essas áreas representam para a pecuária brasileira, existe uma ineficiência na sua utilização. A crescente competitividade do mercado exige a necessidade de maiores informações que contribuam para exploração mais racional e produtiva das gramíneas que pertencem as essas pastagens.

Diante do exposto, os objetivos do trabalho foram avaliar o desempenho de [Brachiaria mutica (Forsk) Stapf e Echinochloa polystachya (H.B.K) Hitch.] tolerantes ao excesso hídrico por alagamento, cultivadas em dois Plintossolos (glei húmicos), coletados na Ilha de Marajó, submetidos a duas condições de umidade: alagamento e capacidade de campo por meio de fotossíntese, condutância estomática, atividade da álcool desidrogenase, produção de matéria seca da parte aérea e raiz, composição química e qualidade das forragens, além disso, verificou-se alterações nas características químicas dos solos sob excesso hídrico que pudessem influenciar no desempenho das espécies estudadas. 


\section{REVISÃO DE LITERATURA}

\subsection{Solos sob inundação}

Nos ecossistemas inundáveis, naturais ou artificiais, como matas ciliares, várzeas, igapós e áreas de depleção marginais, ocorrem sérias mudanças nos processos físicos, químicos e biológicos do solo. Entretanto, a natureza de tais mudanças, depende de características fisico-químicas intrínsecas do mesmo, bem como, da duração do excesso de água.

A destruição da estrutura do solo devido o excesso hídrico é também, um dos importantes fatores causadores do desequilíbrio no sistema solo-planta. O rompimento dos agregados do solo é resultado da redução da coesão entre as partículas devido ao aumento do conteúdo de água, defloculação da argila em função da diluição da solução do solo, e destruição dos agentes cimetantes, entre outros (Sanchez, 1984).

As principais mudanças químicas decorrentes do excesso hídrico são: desaparecimento de oxigênio; acúmulo de dióxido de carbono; decomposição mais lenta da matéria orgânica; transformações do nitrogênio; redução de ferro, manganês e sulfato; e acúmulo de compostos tóxicos. Nos processos de obtenção de energia pelos organismos, surgem reações que resultam na transferência de elétrons de substâncias que servem como fontes de energia, para produtos que se tornam frutos da respiração. Metais sujeitos a oxi-redução, como manganês e ferro, podem ser reduzidos a formas de menor valência, portanto também recebendo elétrons, substituindo assim o papel do oxigênio (Raij, 1991). 


\subsection{Potencial de oxirredução e pH em solos inundados}

Do ponto de vista químico, a principal diferença entre um solo submerso e um solo bem drenado é que o solo submerso está em estado de redução. Um solo submerso apresenta coloração cinza ou esverdeada na camada reduzida tem baixo potencial de oxirredução e contém íons e gases na forma reduzida, como: $\mathrm{NH}_{4}{ }^{+}, \mathrm{Mn}^{2+}, \mathrm{Fe}^{2+}, \mathrm{CH}_{4} \mathrm{e}$ $\mathrm{H}_{2} \mathrm{~S}$. Essa redução nos solos é consequência da respiração de bactérias anaeróbias do solo. Durante a respiração a matéria orgânica é oxidada e os componentes do solo são reduzidos (Ponnamperuma, 1972).

A oxirredução é uma reação química em que elétrons são transferidos de um doador para um aceptor. A fonte de elétrons para a redução, em solos inundados, normalmente é a matéria orgânica (Borges Jr, 1997).

Em uma reação reversível de oxirredução, essa força pode ser medida em calorias ou em volts. A mudança em energia livre, $\Delta \mathrm{G}$, para a redução, é dada pela equação:

$$
\begin{gathered}
\text { Ox }+ \text { ne }^{-} \Rightarrow \text { Red } \\
\Delta G=\Delta \mathbf{G}^{\mathbf{0}}+\mathbf{R T} \ln (\mathbf{R e d}) /(\mathbf{O x})
\end{gathered}
$$

em que Red e Ox são as atividades das espécies reduzida e oxidada, respectivamente, n é o número de elétrons, $\mathrm{R}$ é a constante universal dos gases, $\mathrm{T}$ é a temperatura em graus Kelvin, $\Delta G$ é a alteração de energia livre e $\Delta G^{0}$ é a variação de energia livre padrão. Convertendo calorias para volts usando a relação $\Delta \mathrm{G}=-\mathrm{nEF}$, tem-se:

$$
\mathrm{E}=\mathrm{E}^{0}+\underset{n F}{\underline{R T}} \ln \underline{(\mathrm{Ox})}
$$

em que E é o potencial da reação, $\mathrm{E}^{0}$ é o potencial-padrão e F é a constante de Faraday. Se E é medido contra um eletrodo-padrão de hidrogênio, é denotado Eh e a equação torna-se:

$$
E h=E^{0}+\frac{R T}{n F \quad} \quad \frac{\ln (O x)}{(\operatorname{Red})}
$$

Eh é a quantidade medida da tendência de um dado sistema ser susceptível a oxidação ou redução. O Eh é positivo e alto em sistemas fortemente oxidados, e baixo e 
negativo em sistemas fortemente reduzidos. Quando um solo é submerso, seu Eh decresce durante os primeiros dias, em seguida aumenta e depois decresce novamente, de forma assintótica, para valores característicos do solo, após 8-12 semanas de submersão (Borges Jr, 1997). A velocidade e a magnitude do decréscimo do Eh dependem do tipo e da quantidade da matéria orgânica, da natureza e quantidade dos aceptores de elétrons, da temperatura e do tempo de submersão (Ponnamperuma, 1972).

Em solos inundados, o decréscimo inicial rápido do Eh aparentemente deve-se à liberação de substâncias redutoras, acompanhando a exaustão de oxigênio. Uma vez consumido todo o oxigênio, ocorre o estabelecimento de microrganismos anaeróbios, sendo os nitratos transformados em nitritos que, por sua vez, são transformados em $\mathrm{N}_{2}$ e $\mathrm{N}_{2} \mathrm{O}$, e liberados para a atmosfera. Posteriormente, ocorrem as reduções dos óxidos de manganês a $\mathrm{Mn}^{2+}$, dos óxidos de ferro a $\mathrm{Fe}^{2+}$, e do sulfato a sulfeto, obedecendo a essa ordem à medida que o potencial redox diminui. Dentre os fatores que influenciam a mudança do Eh têm-se: 1) solos com alto teor de nitrato, mais que 275 mg/l, apresentam potencial positivo por várias semanas após a submersão; 2) solos com baixo teor de matéria orgânica (menor que 1,5 dag/kg) ou alto teor em manganês (mais que 0,2 dag/kg), mantêm potencial positivo por uns seis meses após submersão; 3) solos com baixa atividade de manganês e ferro, com mais de 3 dag/kg de matéria orgânica, alcançam valores de Eh entre -0,2 e -0,3 V com duas semanas de submersão; e 4) em condições de potencial estável após várias semanas de submersão, os valores de Eh oscilam entre 0.2 e -0.3 V (Ponnamperuma, 1972).

A temperatura acima e abaixo de $25^{\circ} \mathrm{C}$ retarda o decréscimo do Eh, porém com intensidade variável de acordo com o solo. O atraso na redução é mais pronunciado em solos ácidos, e dificilmente ocorre em solos com alto teor de matéria orgânica (Ponnamperuma, 1972).

O aumento do pH, em solos ácidos, deve-se a reações de redução, onde ocorre o consumo de prótons. Entretanto, esse aumento dependerá da relação entre os prótons consumidos e o número de elétrons envolvidos na reação, com as reações de redução do ferro e do manganês apresentando as mais altas relações $\mathrm{H}^{+} / \mathrm{e}^{-}$(3:1 e 2:1, respectivamente). Também, a maioria dos solos ácidos apresentam mais óxidos de $\mathrm{Fe}^{3+}$ 
hidratado do que qualquer outro óxido. Dessa forma, o aumento do $\mathrm{pH}$ é largamente influenciado pelos óxidos de ferro. $\mathrm{O}$ valor de $\mathrm{pH}$ é profundamente influenciado pelo equilíbrio de óxidos, carbonatos, sulfatos, fosfatos e silicatos, em solos submersos. Esse equilíbrio regula a precipitação e dissolução de sólidos, a sorção, a dessorção e a concentração de íons importantes na nutrição de plantas (Ponnamperuma, 1972).

\subsection{Os nutrientes, formas, disponibilidade e toxidez em solos inundados}

As mudanças físicas, químicas, eletroquímicas e biológicas causadas pelo excesso hídrico influenciam fortemente a fertilidade do solo. Quando os solos são inundados ocorre acúmulo de nitrogênio, a amônia fica acumulada no lugar do nitrato e a maior parte do nitrogênio é perdida por desnitrificação, sendo menos nitrogênio mobilizado; ocorrendo também redução de manganês, ferro e sulfato que são utilizados como aceptores de elétrons na respiração de bactérias, ficando reduzidos a $\mathrm{Mn}^{2+}, \mathrm{Fe}^{2+}$, $\mathrm{H}_{2} \mathrm{~S}$ respectivamente (Ponnamperuma, 1984).

A mineralização do nitrogênio a partir de compostos orgânicos envolve duas transformações (aminação e amonificação) que levam o nitrogênio até a forma amoniacal $\left(\mathrm{NH}_{4}{ }^{+}\right.$); pode-se incluir ainda a nitrificação (passagem do $\mathrm{NH}_{4}{ }^{+} \rightarrow \mathrm{NO}_{3}{ }^{-}$). As duas primeiras são produzidas por microrganismos heterotróficos (requerem carbono como fonte de energia) e a última por autotróficos.

As perdas de nitrogênio por volatilização podem ocorrer devido principalmente as reações como $\left(\mathrm{NH}_{4}{ }^{+} \mathrm{OH}^{-} \rightarrow \mathrm{NH}_{3} \uparrow+\mathrm{H}_{2} \mathrm{O}\right.$ ), que podem ser favorecidas em solos originalmente ácidos, mas que tiveram seu $\mathrm{pH}$ elevado próximo a neutralidade durante o excesso hídrico. Além dessa, existem outras reações que ocorrem envolvendo a decomposição de $\mathrm{NO}_{2}{ }^{-}$, como a decomposição do nitrito de amônio $\left(\mathrm{NH}_{4} \mathrm{NO}_{2} \rightarrow 2 \mathrm{H}_{2} \mathrm{O}\right.$ $+\mathrm{N}_{2} \uparrow$ ). Porém, sob condições anaeróbias, onde se encontram os solos inundados, as perdas por volatilização através de reações biológicas (conhecidas como desnitrificação) são significativamente elevadas (Barros, 1990). Portanto, solos inundados não podem receber adubações nitrogenadas com fontes de nitratos como o nitrato de amônio, devido a perdas por desnitrificação serem elevadas nessas circunstâncias. 
O enxofre assim como o nitrogênio encontra-se no solo em sua maioria na forma orgânica e também possui processos dinâmicos. Na mineralização do enxofre, as proteínas, peptídeos e outros compostos orgânicos com enxofre, são despolimerizados até aminoácidos, tiosulfatos e tiouréia.

Sob condições redutoras dos meios anaeróbios, o $\mathrm{SO}_{4}{ }^{2-}$ não é estável e é reduzido a sulfeto $\left(\mathrm{S}^{2-}, \mathrm{HS}^{-}, \mathrm{H}_{2} \mathrm{~S}\right)$ pelas bactérias Desulfovibrio e Desulfoto maculum. Logo os sulfetos são as formas predominantes em solos alagados, e podem reagir com o ferro formando FeS e evitando o efeito tóxico do excesso de ferro. Quando esses solos são drenados $\mathrm{o} \mathrm{H}_{2} \mathrm{~S}$, resultante da mineralização da matéria orgânica, pode ser oxidado, em condições de bom arejamento, para $\mathrm{SO}_{4}{ }^{2-}$, e pode ser absorvido pelas plantas ou imobilizado por microrganismos (Alvares, 1990).

Na oxidação da matéria orgânica pelos microrganismos há produção de ATP, elétrons, prótons e metabólitos. Os íons $\mathrm{Fe}^{3+}$ são utilizados como receptores de elétrons, após o consumo de nitrato e manganês do sistema. Portanto, há participação de microrganismos no mecanismo de redução de óxidos de ferro, uma vez que somente a presença de água não é suficiente para haver redução (Kampf, 1988).

A toxicidade de ferro pode ocorrer diretamente com a absorção excessiva do nutriente pela planta, o que lhe danifica as células, ou indiretamente, pela deficiência de outros nutrientes. Em solos inundados, com baixas concentrações de cálcio, magnésio, fósforo e manganês, a absorção de ferro aumenta, tornando-se tóxica (Borges Jr.,1997).

O manganês é outro elemento que merece destaque do ponto de vista do seu comportamento e disponibilidade em solos inundados. O manganês existente no solo pode ser dividido em: presente na estruturas de minerais, organicamente complexado, trocável e na solução do solo. O equilíbrio entre essas formas é principalmente influenciado pelo pH e condições de oxiredução do solo (Borkert, 1991).

As plantas absorvem o manganês na forma iônica $\mathrm{Mn}^{2+}$ e o suprimento às raízes é efetuado por fluxo de massa e por difusão. Esses processos são muito afetados pela concentração do elemento na solução do solo, a qual por sua vez é influenciado pelo pH, potencial redox, atividade microbiana e teor de matéria orgânica. 
O potencial redox é um fator que afeta de maneira sensível a disponibilidade de manganês. Quando o potencial decresce em solos inundados, a disponibilidade do manganês e também do ferro, como já foi visto, inicialmente aumenta por causa da redução e da dissolução de óxidos desses elementos no solo. Já se o potencial redox decresce para valores muito baixos, possivelmente sulfetos de manganês possam ser formados, o que irá levar o elemento a ser indisponível para as culturas. Quando esses solos são drenados o potencial redox aumenta rapidamente e a solução do solo pode se tornar super saturada com óxidos de ferro e manganês, e a co-precipitação de outros metais com esses dois elementos pode ser importante (Borkert, 1991).

\subsection{Fisiologia de plantas sob excesso hídrico}

A hipoxia ou anoxia são os principais fatores limitantes que reduzem a respiração aeróbia e a absorção de minerais e água pelas raízes.

As plantas susceptíveis ao excesso hídrico exibem mudanças nos processos metabólicos e fisiológicos. Fatores como: redução na condutância radicular ocorrendo murchamento do vegetal, fechamento estomático, redução da absorção de água e da taxa de fotossíntese (translocação de carbono), estão entre as primeiras respostas ao encharcamento (Baruch, 1994). Outras mudanças em seqüência incluem diminuição na permeabilidade das raízes, alterações no balanço de hormônio do crescimento, epinastia das folhas, clorose e abscisão, levando a interrupção do crescimento vegetativo e reprodutivo.

Segundo Humphreys (1981), a inundação ou má drenagem em solos onde vegetam espécies forrageiras susceptíveis ao excesso hídrico, são fatores que atuam diretamente na deficiência de oxigênio para o desenvolvimento de raízes, sendo portanto causa de morte dessas forrageiras, pois reduz a respiração da raiz, diminuindo a disponibilidade energética e a absorção de nutrientes. Nessas espécies, a rapidez do dano sendo função da redução da respiração bem como produção de etanol e acetaldeido. O fosfoenolpiruvato (PEP) nas raízes das espécies sensíveis é carboxilado pela PEP- 
carboxilase a oxaloacetato, logo é convertido a malato pela desidrogenase málica, em seguida a enzima málica, impede seu acúmulo e o malato é convertido a piruvato, pela ação da $\alpha$-carboxilase que é então transformado a acetaldeido.

Crawford (1993), revendo respostas de plantas sob alagamento descreveu sobre a abilidade das espécies em reduzir o impacto causado pelo estresse, em função de diferentes estratégias de sobrevivência por meio de mecanismos de "tolerância” e “avoidance” sem tradução para o português, como um modo de “evitar” ou escapar de ambientes anóxicos.

Segundo o autor, a tolerância envolve adaptações metabólicas de acordo com espécies, plantas e tecidos e que consistem na regulação da respiração, no armazenamento de energia, no metabolismo lipídico e atividade mitocondrial, na síntese de etileno e em adaptações fotossintéticas. A conseqüência dessas adaptações da respiração anaeróbica no metabolismo celular é um dos fatores que mais interferem nos processos fisiológicos.

A troca da respiração aeróbia pela anaeróbia afeta severamente a disponibilidade de energia, requerendo grande quantidade da reserva de carboidratos existentes na planta, gerando produtos finais potencialmente tóxicos e causando acidose citoplasmática.

Os carboidratos são fornecidos para respiração anaeróbia a partir de fonte de reserva ou por meio da translocação dos fotoassimilados provenientes das folhas ativas fotossinteticamente. A translocação é sensível as condições de anaerobiose e dependendo da planta, não consegue sustentar a alta demanda de carboidratos exigidos pelas raízes durante o alagamento, com exceção das espécies tolerantes que possuem aerênquimas. Como consequência, a abilidade em armazenar grande quantidade de carboidratos em raízes ou rizomas podem conferir a espécie tolerância prolongada a condição de anoxia.

A modificação na hipótese de Crawford propôs que a acidose citoplasmática seria a causa de toxidez durante a anoxia. O baixo $\mathrm{pH}$ conseqüente da síntese de ácido lático e outros ácidos orgânicos, ou estimulado pela fermentação do etanol ou ainda pelo tamponamento de $\mathrm{pH}$ via reações de descarboxilação, seria evitada nos tecidos 
tolerantes. No entanto, os detalhes das possíveis causas continuam sendo assunto de controvérsia no meio científico, em decorrência do número de estratégias metabólicas que parecem estar relacionadas em diferentes plantas para manter a homeostase durante a fermentação glicolítica.

A respiração anaeróbia produz pequena quantidade de ATP por molécula de glicose em comparação a respiração anaeróbia. Por isso, grandes quantidades de carboidratos são requeridas para produção suficiente de ATP a fim de manter as funções vitais das células sob condições de hipoxia ou anoxia.

Os tecidos submetidos a anoxia apresentam demanda elevada por sacarose devido a respiração fermentativa ineficiente acabando por consumir rapidamente todo carboidrato disponível. Essa escassez por falta de energia pode causar danos na membrana mitocondrial pelas alterações morfológicas. Segundo Vartapetian et al. (1977), estudando raízes sob anaerobiose, a mitocôndria desenvolveu forma anormal com a dilatação da crista mitocondrial em poucas horas, na ausência de oxigênio. Porém quando a concentração de oxigênio for restabelecida, a mitocôndria retornou a sua estrutura e capacidade respiratória original.

A anoxia promove danos substanciais sobre o metabolismo celular acarretando em total desaparecimento das proteínas aeróbias e a sua substituição pelas induzidas anaerobicamente. Essas proteínas em sua maior parte são glicolíticas e são traduzidas e transcritas em elevadas quantidades.

Sachs et al. (1996), encontraram em milho submetido a alagamento em que a anoxia estimulou a síntese de grupos protéicos conhecidos como peptídeos anaeróbicos (PAN). Cerca de 20 PAN foram sintetizados dentro de duas horas, muitos dos quais são enzimas envolvidas na glicólise nas quais atuam no aumento na capacidade de respiração fermentativa.

O tipo de PAN está relacionado com a severidade na ausência de oxigenação e em função da espécie. Entre os PAN identificados incluem: sucrose sintase I, fosfohexose isomerase, frutose 1,6-difosfato aldolase, piruvato descarboxilase, lactato desidrogenase e álcool desidrogenase. A deficiência de oxigênio e identificação dos PAN envolvidos em plantas de milho têm sido utilizados com um sistema modelo para 
estudar a regulação genética devido durante a hipoxia, a regulação pode ocorrer em ambos aspectos de transcrição como tradução envolvendo fatores positivos e negativos (Drew, 1990).

As células do sistema radicular ao se tornarem anaeróbias estimulam as vias glicolíticas e fermentativas produzindo grandes quantidades de dióxido de carbono, etanol e/ ou ácido lático.

Crawford (1978) formulou uma teoria metabólica sobre espécies tolerantes ao alagamento em que a premissa básica consistia que o etanol era fitotóxico as plantas alagadas. Entretanto, essa teoria foi refutada por Jackson et al. (1984), ao notar que seria necessária uma concentração dez vezes maior para matar plantas do que as detectadas nas espécies alagadas. Outras inúmeras inconsistências foram relatadas, ao avaliar cultivares de milho e aveia, a tolerância ao alagamento esteve associada à atividade da álcool desidrogenase (ADH) demonstrando que a hipótese de Crawford havia predito o inverso.

Em espécies não tolerantes à anaerobiose radicular, ocorrem rápidas mudanças metabólicas, como a ativação da enzima desidrogenase alcóolica (ADH) que converte acetaldeido gerado na respiração anaeróbia, em etanol (Hook, 1984; Drew, 1992).

As plantas podem remover o etanol pelo transporte para parte aérea via xilema ou por difusão para fora das raízes. Não existem evidências de que o etanol em tecidos afetados seja acumulado a concentrações tóxicas. Para Hook (1984), a persistente preocupação sobre a toxidade do etanol é largamente infundada, pois o mesmo não é ionizado e, portanto eliminado das células. Por outro lado, a anaerobiose parece aumentar a permeabilidade da membrana, conseqüentemente facilitando a eliminação dos metabólitos.

Apesar das controvérsias a respeito da toxidez do etanol, Barta (1980), comparando o excesso hídrico em alfafa e cornichão, essa última considerada como tolerante ao excesso hídrico, determinou que a concentração de etanol em raízes de cornichão foi menor que em alfafa. A atividade da enzima $\mathrm{ADH}$ foi encontrada em níveis similares, logo indicando que o cornichão pode eficientemente remover o etanol das raízes. 
O metabolismo de lipídeos serve com reserva para respiração anaeróbia devido pode ser quebrado em subunidades que podem entrar na via glicolítica ou fermentativa. Entretanto, os lipídeos não são armazenados por espécies de áreas alagadas durante seu período de dormência. A alta demanda por oxigênio para processar lipídeos na respiração, provavelmente, exclui a sua efetividade de armazenamento desses para respiração anaeróbia durante o inverno.

Os lipídeos acumulam em muitos locais dentro da célula durante a anoxia, incluindo mitocôndrias, cloroplastos e lipossomas. O acúmulo é obtido pela grande quantidade de oxigênio necessária para manter a função da membrana é comumente considerada como prejudical nas condições de anaerobiose Todavia, o suprimento de oxigênio torna-se limitado sob tais condições, diminuindo a quantidade de membrana celular e promovendo acúmulo de lipídeos. A exemplo disso, a espécie Echinochloa muricata, apresenta $14 \%$ da massa seca foliar composta por lipídeos sob condições de anaerobiose.

Apesar do acúmulo ser considerado danoso, parece haver algumas vantagens no aumento da concentração lipídica durante a anoxia. A sua síntese na ausência de oxigênio reoxidaria o NADH para $\mathrm{NAD}^{+}$, gerando assim NAD oxidado sem a produção de etanol pela fermentação. $\mathrm{O}$ acúmulo lipídico nas folhas de Echicnochloa muricata resulta da carboxilação de acetil-coenzima A, derivado de carboidratos submetidos a glicólise, esse fluxo de carbono gerado de carboidratos para lipídeos é significativo, o que permite produzir ATP através da glicólise e oxidar o NADH, porém não gerando quantidades extensivas de etanol e que afetaria o abaixamento do $\mathrm{pH}$ da célula. Sendo assim, o armazenamento de lipídeos pode servir como uma fonte importante de energia quando as condições de anaerobiose aparecerem novamente. 
O alagamento provoca alterações no balanço hormonal reduzindo crescimento da parte aérea. Tanto a quantidade como o balanço de vários fitohormônios sofrem rápidas modificações em função do excesso hídrico. O solo submetido a ambiente reduzido leva a aumento da síntese de etileno, auxinas e ácido abscísico (ABA) (Kozlowski, 1984).

$\mathrm{O}$ aumento desses compostos na parte aérea das plantas pode variavelmente refletir diferenças em sua síntese, destruição ou translocação. A concentração de giberilinas e citocininas em caules e raízes em geral, sofrem reduções em função do alagamento. Nota-se que, a produção individual de hormônios de crescimento é influenciada por concentrações de outros hormônios. Por exemplo, auxinas e citocininas aumentam a produção de etileno, sendo o efeito da auxina ainda maior na sua produção. O ABA e giberilinas também estimulam a produção de etileno.

Entre os vários hormônios afetados pelo alagamento, o etileno é que o mais se destaca, devido ao aumento na sua concentração. Esse aumento é atribuído a diversos fatores envolvendo o aumento da síntese, redução do movimento para fora das raízes e a absorção pela planta gerada pelos microorganismos do solo sob anaerobiose. A síntese do etileno aumenta sob condições de hipoxia quando o ácido aminociclopropano -1carboxílico (ACC), precursor do etileno é estimulado. O ACC é transportado para partes aeradas da planta, seja a parte aérea ou raízes e convertido a etileno pela ACC - oxidase. Por ser menos solúvel em água do que em ar, maiores quantidades desse hormônio são retidas dentro dos tecidos vegetais quando ocorre o alagamento.

Durante o alagamento, o transporte de auxinas da base do caule para folhas é inibido, resultando no aumento da auxina no caule. A concentração de etileno endógeno aumenta rapidamente após o alagamento, gerando maior sensibilidade dos tecidos à auxina, a qual estimula a formação de lenticelas e raízes adventícias na base do caule localizado acima do nível da água.

Outra forte evidência do etileno sob a anatomia de muitas plantas sob condições alagadas está relacionada à formação de aerênquima. Na maioria das plantas de regiões alagadas, o desenvolvimento de aerênquimas e caules mais porosos é geneticamente controlado. Em tais plantas, o aerênquima desenvolve-se na presença ou ausência de condições anaeróbias. Contudo, em plantas como milho, o aerênquima somente ocorre 
durante o estresse por alagamento, o que de acordo com Drew et al. (1979), demonstraram que a hipoxia induz a síntese de etileno nas raízes e que está diretamente relacionado a formação de aerênquima. Além disso, a hipoxia e o etileno estão correlacionados com o aumento da atividade da celulase que degrada a parede celular gerando espaços intracelulares responsáveis pelo transporte de oxigênio até o sistema radicular.

O etileno possui influência na elongação da parte aérea de plantas aquáticas submersas e em muitas que emergem na superfície da água. A elongação da parte aérea em espécies de áreas inundáveis pode estar relacionada com a ação das giberilinas e auxinas. Em ambos os casos, a sensibilidade do tecido a esses fitohormônios é aumentada em função de altas concentrações de etileno.

As plantas que “evitam” ou “escapam” de condições de anaerobiose requerem desenvolvimento de mecanismos de transporte de oxigênio para o sistema radicular através de canais internos. Essas espécies adotam mecanismos que acabam alterando seus padrões de crescimento, no entanto, não necessariamente são consideradas tolerantes a baixas concentrações de oxigênio no solo.

Os mecanismos de adaptação asseguram a renovação do suprimento de oxigênio para as raízes submersas e que consistem em desenvolver canais preenchidos por gases, chamados de aerênquimas, os quais permitem o movimento do oxigênio da parte aérea para as raízes sob condições de anoxia (Jackson, 1989).

Outro mecanismo de adaptação, no qual a planta “evita” as injúrias causadas pelo alagamento, é a formação de raízes adventícias, como alternativa de redução de impacto. As raízes adventícias emergem a partir de partes dos colmos submersos em plantas sob alagamento. Esse mecanismo de adaptação permite que novas raízes substituam a função do sistema radicular original. O crescimento horizontal dessas raízes próximo a superfície da água, juntamente com a localização no colmo perto dos locais de formação de aerênquimas, favorecem maior disponibilidade de oxigênio para essas raízes do que o antigo sistema radicular danificado (Jackson e Drew, 1984).

Regehr et al. (1975), descreveram que o transporte de água assim como o de ar também é melhorado pelas raízes adventícias em comparação as raízes originais sob 
anoxia, promovendo reabertura estomática durante períodos prolongados de alagamento atribuído à transferência de funções do sistema radicular afetado para as raízes adventícias recém desenvolvidas.

Em espécies adaptadas a solos inundados, geralmente não ocorre fechamento estomático e o metabolismo radicular não é alterado consideravelmente pela anoxia, devido ao eficiente sistema de transporte e difusão de oxigênio nas raízes dessas espécies (Jackson e Drew, 1984).

\subsection{Espécies forrageiras}

As diversas espécies forrageiras variam quanto à tolerância ao excesso de água: desde espécies não tolerantes, de tolerância média como a setária, até espécies tolerantes como a Brachiaria mutica e a canarana verdadeira (planta descrita como semi-aquática). A seguir serão apresentadas características botânicas, dados de produtividade, bem como seus usos.

\subsubsection{Brachiaria mutica (Forsk) Stapf}

A B. mutica é conhecida comumente como capim fino, capim angola, capim bengo, capim de planta, capim-do-pará. Foi inicialmente classificado como Panicum muticum (Forsk), posteriormente Panicum purpurencens (Radddi) e também Panicum barbinode (Trin). Considerada de origem africana, mas há quem diga ser nativa do Brasil. É uma espécie perene, apresenta bom perfilhamento, emitindo vigorosos estolões, longos e rasteiros, que crescem rapidamente e emitem raízes na região dos nós, cobrindo o terreno em curto espaço de tempo (Pupo, 1979). É uma das poucas forrageiras utilizadas em larga escala nas fazendas, especialmente nos trópicos da América do Sul e Central (Seiffert, 1984).

O capim fino tem habilidade de sobreviver ao encharcamento do solo, nas regiões tropicais e subtropicais, e de crescer em ambientes de água parada, ou que corre lentamente, sendo importante para o aproveitamento de áreas pantanosas ou de várzeas de rios (Bogdan, 1977; Skerman e Riveiros, 1990). 
Apresenta moderada tolerância a solos salinos, adaptando-se melhor a solos hidromórficos e aluviões de boa fertilidade. Possui baixo grau de tolerância ao sombreamento, sendo resistente ao ataque de cigarrinhas. Não apresenta o problema de fotossensibilização (Soares filho, 1994).

Haddade (1998), avaliou três espécies forrageiras (Brachiaria decumbens, Brachiaria mutica e Setária anceps), cultivadas em vasos submetidas a diferentes períodos de alagamento (10, 20 e 30 dias com e sem alagamento), e a dois manejos (com e sem corte anterior aos tratamentos). A Brachiaria mutica foi a mais adaptada, não tendo modificado seu crescimento mesmo nos maiores períodos de excesso hídrico, sendo a Brachiaria decumbens a menos adaptada a esse tipo de estresse hídrico.

\subsubsection{Echinochloa polystachya (H.B.K) Hitch}

A E. polystachya é conhecida comumente como canarana verdadeira, canarana fluvial, aleman grass. É uma gramínea perene, estolonífera, que possui colmos avermelhados, suculentos (medula esponjosa), com sulco longitudinal externo característico. Nativa do Brasil é muito encontrada na Bacia Amazônica, povoando terrenos alagadiços, onde vegeta com exuberância. Chega a atingir dois metros de altura, sendo muito apreciada pelo gado. É uma forrageira própria dos climas quentes e úmidos, mostrando-se muito sensível à seca e ao frio (Pupo, 1979).

Wildin (1989), relatou a adaptação da espécie a solos de baixa fertilidade, respondendo vigorosamente a fertilizantes, especialmente adubações nitrogenadas, competindo satisfatoriamente com Brachiaria mutica onde a lâmina de água é muito funda para essa, vegetando em profundidades de até $60 \mathrm{~cm}$. Sua propagação é realizada por intermédio de mudas, pois há pouca produção de sementes.

Produz de 100 a 150 t/ha de matéria verde, apresentando digestibilidade da matéria seca depois de 41, 48, 55 e 62 dias, de 63; 62,2; 59,1 e 60,5\% respectivamente, assim como para proteína bruta, 10,3; 9,1; 8,9 e 8,2 \% respectivamente (Wildin, 1989 e Mitidieri, 1992).

Camarão e Marques (1995), caracterizaram o ambiente, produção de massa seca (Kg de MS/ha/ano) e composição química de 23 gramíneas nativas de terra inundável do 
tropico úmido brasileiro, entre as quais a E. polystachya se destacou como umas das mais importantes sob o ponto de vista de alimentação animal, por suportar ambiente de elevada precipitação pluviométrica (1500 a 3500 mm/ano) e em solos hidromóficos (Glei húmico e pouco húmico) apresentando produção de MS variável entre 9.891 a $9.675 \mathrm{Kg}$ de MS/ha/ano, teores de proteína bruta (PB) e fibra detergente neutro (FDN) antes do florescimento de 9,8 e 59,1\% , respectivamente.

Vittori (1998), avaliou o potencial de produção de matéria seca de 7 gramíneas (Echinochloa polystachya, Acroceres macrum, Brachiaria mutica, Brachiaria arrecta, Hemarthria altissima, Setaria anceps e Tifton 85) em quatro idades de corte (14, 28, 42 e 56 dias). Até 42 dias as produções de MS não diferiram entre as espécies, no entanto, a E. polystachya apresentou produção no corte de 56 dias e total (somatória dos cortes) superior as demais espécies, alcançando 11,2 e 21 t/ha respectivamente.

Apesar do alto potencial qualitativo e quantitativo das pastagens de terra inundável, os conhecimentos atuais são incipientes, e as pesquisas em relação ao valor nutritivo, fisiologia, comportamento sob pastejo, respostas a fertilizações são escassas e sem continuidade.

\subsection{Experimentos avaliando excesso hídrico}

Platzeck (1989), estudou o efeito do estresse hídrico no estabelecimento de Brachiaria humidicola e Setaria anceps, verificando que: 1) as sementes destas duas espécies não germinam sob água; para um período de 10 dias sob inundação, a $B$. humidicola teve sua germinação reduzida em $42 \%$, enquanto que para a Setária anceps houve acréscimo de germinação de 31\%; 2) o tempo de excesso hídrico afeta a velocidade de germinação, bem como o desenvolvimento das plantas. As plantas de $B$. humidicola alteraram seu crescimento e morfologia, pois as mesmas eram mais altas que as não inundadas. As plantas maiores, que apresentaram alguma porção da parte aérea exposta ao ar foram mais resistentes as que tinham sido totalmente submersas. Plantas com 30 dias suportaram excesso hídrico por até 35 dias, com uma lâmina de 4 - 5 cm.

Piedade et al., (1991), em trabalho sobre produtividade da gramínea $E$. polystachya em áreas inundadas da região amazônica, encontraram produção recorde de 
matéria seca de 80 t/ha em condições naturais para esta espécie e a comparam com a produtividade máxima já obtida por uma forrageira, que foi de 85 t/ha para o capim elefante sob intenso manejo. Similarmente, confrontaram a produção de matéria seca por unidade interceptada de radiação solar de 2,3 g/MJ obtido para a E. polystachya, comparativamente com máximo obtido por uma espécie $\mathrm{C}_{4}$ de 2,4 g/MJ do Pennisetum tyfhoides sob irrigação e intenso manejo, concluindo que a ocorrência da E. polystachya no centro da região amazônica, é um raro exemplo de como o máximo potencial fotossintético de uma planta $\mathrm{C}_{4}$ pode ser atingido em ambientes naturais, mostrando a significância da espécie em persistir no seu habitat.

Oliveira (1994), estudou seis gramíneas (entre elas B. mutica e E. polystachya) para o estabelecimento em áreas sujeitas a excesso hídrico, sob três doses diferentes de fertilidade, verificou que as braquiárias e a $E$. polystachya, devido ao seu bom perfilhamento, foram as espécies que cobriram o solo mais rapidamente, enquanto que a produção de matéria seca foi nitidamente influenciada pela fertilidade do solo. A E. pyramidalis foi a mais sensível, respondendo melhor a adubações crescentes.

Baruch (1994), estudando gramíneas forrageiras (B. mutica, E. polystachya, A. gayanus e $H$. rufa) submetidas à seca e excesso hídrico, em relação a aspectos fisiológicos e bioquímicos entre os quais: taxa fotossintética, condutância estomática e atividade desidrogenase alcoólica (ADH), indicaram que a seca moderada produziu efeitos similares em todas as gramíneas causando redução na condutância estomática e logo redução da fotossíntese. As respostas ao excesso hídrico variaram entre as espécies: A. gayanus e $H$. rufa apresentaram rápido fechamento estomático contribuindo para redução no turgor das folhas. Essa baixa condutância estomática foi responsável pela redução da fotossíntese líquida e da taxa de crescimento. A atividade de ADH em A. gayanus foi incrementada significativamente, mostrando que essa espécie foi mais sensível ao alagamento. Contudo, a abertura estomática, fotossíntese líquida e atividade de $\mathrm{ADH}$ na $B$. mutica, E. polystachya não foram afetadas pelo excesso hídrico. Essa melhor adaptação das duas últimas espécies deveu-se, segundo o autor, ao desenvolvimento de raízes adventícias e a melhor difusão de gases nos estolões e raízes, devido a tecidos aerenquimáticos que permitiram a oxigenação e a atividade radicular. 
Baruch e Mérida (1995), em estudo sobre o efeito da seca e excesso hídrico na morfologia e anatomia das raízes de 4 gramíneas tropicais (B. mutica, E. polystachya, $A$. gayanus e $H$. rufa) verificaram que as mudanças foram mais evidentes no excesso hídrico que na seca; as principais respostas foram o desenvolvimento de tecido aerênquimatoso no córtex da raiz, sob excesso hídrico. A B. mutica e E. polystachya, plantas tipicamente de regiões alagadas, continham maiores proporções de aerênquima, compondo de 40-49\% da área transversal da raiz. Esses resultados mostram que existem espécies que possuem constituição já adaptada ao alagamento, independente do ambiente onde vegetam, espécies que se adaptam às mudanças ambientais, e outras que não possuem essa plasticidade.

Huang (2000), descreveu que absorção de nutrientes como nitrogênio, potássio e fósforo freqüentemente são inibidos pelo alagamento dos solos, o qual reduz o suprimento para parte aérea das plantas. Contudo, outros nutrientes têm seus teores afetados de maneira inversa como magnésio e zinco que tendem a acumular nos tecidos radiculares.

Alam (1999) em revisão realizada sobre o efeito do alagamento sobre a absorção de nutrientes citou que a solubilidade de zinco, cobre, boro e molibdênio geralmente alteram com a época e as condições de crescimento das plantas. Em relação ao ferro e manganês há tendência em aumentar favorecendo a solubilidade do zinco e cobre.

Ishida (1998) estudou os efeitos de diferentes tempos e alturas de submersão (somente sistema radicular, planta total) sobre o crescimento, fotossíntese, condutância estomática em folhas de Setaria anceps e Paspalum repens. Os resultados obtidos em relação ao tempo e alturas de inundação demonstraram que houve formação de aerênquima, lenticelas e raízes adventícias em ambas as espécies quando totalmente submersas, no entanto apresentando baixas taxas de fotossintéticas. Dentre as duas espécies, o Paspalum repens, apresentou melhores resultados em algumas das características avaliadas como maior produção de biomassa, sugerindo ser melhor adaptada a áreas sujeitas a inundações.

Tribuzy (1998), avaliando o metabolismo do carbono e nitrogênio em plantas de ingá submetidas à baixa disponibilidade de oxigênio, por meio de trocas gasosas, 
atividade de várias enzimas entre elas, a $\mathrm{ADH}$ verificou que o estresse afetou o crescimento das plantas que sofreram total submersão, bem como redução da capacidade fotossintética atribuída a problemas na fixação e redução do carbono, e maior atividade da ADH nos tecidos estressados.

Moraes et al. (2001) estudaram o comportamento de quatro espécies forrageiras em resposta ao estresse anóxico, avaliando o crescimento durante o déficit de oxigênio e sobrevivência após o estresse, associando-os a alterações no teor de proteínas e à atividade da $\mathrm{ADH}$. Os resultados demonstraram que a Echinochloa polystachya e Brachiaria mutica apresentaram paralisação no crescimento durante o período, porém com elevada taxa de sobrevivência após o estresse. Relações entre teor de proteínas e tolerância anoxia não foram observadas. Entretanto, observou-se que a atividade da $\mathrm{ADH}$ nas folhas e raízes em anoxia apresentou-se maior ou igual quando as plantas estiveram sob aeração normal. 


\section{MATERIAL E MÉTODOS}

\subsection{Localização do experimento}

O experimento foi conduzido em casa-de-vegetação do Laboratório de Plantas Cultivadas sob Condições de Estresse do Departamento de Ciências Biológicas da ESALQ - Escola Superior de Agricultura “Luiz de Queiroz”, situada em Piracicaba - SP, no período de novembro de 2002 a maio de 2003.

\subsection{Solos e adubação}

Os solos utilizados foram coletados entre os dias 08 e 12 de janeiro de 2001, sendo oriundos da Fazenda Ilha Nova, município de Salvaterra, na Ilha de Marajó - PA, cujas coordenadas geográficas estão entre 00²'’ $00^{\circ} 73^{\prime}$ de latitude Sul e $48^{\circ} 75^{\prime}$ 4874’ de longitude Oeste.

O volume total de cada solo foi de aproximadamente $840 \mathrm{~kg}$, sendo composto a partir de 20 pontos distintos de coleta, tendo cada um desses pontos uma área de 60 x 60 cm de largura, e $20 \mathrm{~cm}$ de profundidade. Após a coleta, esses foram deslocados para uma área coberta onde foram distribuídos sobre lonas plásticas para secagem por um período de 48 a 72 horas. Os solos, depois de peneirados foram homogeneizados e acondicionados em sacos com capacidade de $40 \mathrm{~kg}$ cada.

Os solos foram armazenados em abrigo próximo à casa de vegetação até o início experimento, onde sofreram uma nova homogeneização, e retiradas amostras para análises físico-químicas. Em função das análises realizadas, observam-se características distintas em cada solo, os quais foram denominados de solo 1 e solo 2 (Tabelas 1 a 3). 
Tabela 1. Análise granulométrica (valores em \%)

\begin{tabular}{lcccl}
\hline Solo & Areia & Silte & Argila & Classe de textura \\
\hline Solo 1 & 45 & 41 & 14 & arenoso \\
Solo 2 & 8 & 34 & 58 & muito argiloso \\
\hline
\end{tabular}

Tabela 2. Análise química dos solos

\begin{tabular}{|c|c|c|c|c|c|c|c|c|c|c|c|c|c|}
\hline \multirow[t]{2}{*}{ Solo } & \multirow{2}{*}{$\begin{array}{c}\mathrm{pH} \\
\mathrm{CaCl}_{2}\end{array}$} & \multirow{2}{*}{$\begin{array}{l}\text { M. O } \\
\text { g dm }\end{array}$} & \multirow{2}{*}{\multicolumn{2}{|c|}{$\frac{\mathrm{P} \quad \mathrm{S}}{\mathrm{mg} \mathrm{\textrm {dm } ^ { - 3 }}}$}} & $\bar{K}$ & $\mathrm{Ca}$ & $\mathrm{Mg}$ & $\mathrm{Al}$ & $\mathrm{H}+\mathrm{Al}$ & SB & $\mathrm{T}$ & $\mathrm{V}$ & $\mathrm{m}$ \\
\hline & & & & & \multicolumn{7}{|c|}{$\mathrm{mmol}_{\mathrm{c}} \mathrm{dm}^{-3}$} & \multicolumn{2}{|c|}{$\%$} \\
\hline Solo 1 & 3,6 & 20 & 11 & 13 & 2,6 & 5 & 3 & 13 & 52 & 10,6 & 62,6 & 17 & 55 \\
\hline Solo 2 & 3,9 & 27 & 1 & 24 & 3,8 & 2 & 21 & 32 & 166 & 26,8 & 192,8 & 14 & 54 \\
\hline
\end{tabular}

Tabela 3. Análise de micronutrientes, sódio e condutividade

\begin{tabular}{|c|c|c|c|c|c|c|c|}
\hline \multirow[t]{2}{*}{ Solo } & B & $\mathrm{Cu}$ & $\mathrm{Fe}$ & $\mathrm{Mn}$ & $\mathrm{Zn}$ & \multirow{2}{*}{$\begin{array}{c}\mathrm{Na} \\
\mathrm{mmol}_{\mathrm{c}} \mathrm{dm}^{-3}\end{array}$} & \multirow{2}{*}{$\begin{array}{c}\text { Condutividade } \\
\mathrm{dS} \mathrm{m}^{-1}\end{array}$} \\
\hline & \multicolumn{5}{|c|}{$\mathrm{mg} \mathrm{dm}^{-3}$} & & \\
\hline Solo 1 & 0,60 & 0,5 & 281 & 9,8 & 2,5 & 1,21 & 0,55 \\
\hline Solo 2 & 0,86 & 1,1 & 156 & 24 & 3,2 & 4,60 & 1,06 \\
\hline
\end{tabular}

De acordo com a última nomenclatura da EMBRAPA (1999), o solo 1 é classificado como Plintossolo pétrico litoplíntico e o solo 2 como Plintossolo háplico eutrófico (Figura 1).
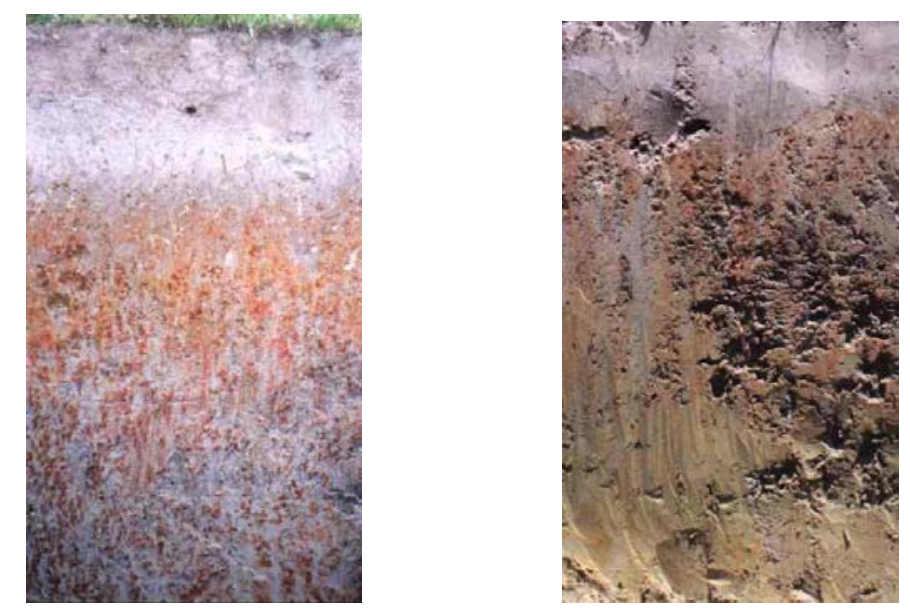

Figura 1 - Trincheiras abertas (80 cm de profundidade): Solo1 à esquerda e Solo2 à direita, Fazenda Ilha Nova, Salvaterra - PA 
Os solos foram desensacados e revolvidos, não havendo a necessidade de peneirá-los, pois os mesmos já estavam devidamente preparados. Utilizou-se $30 \mathrm{~kg}$ de solo para cada unidade experimental, pesado individualmente, onde foi incorporado o corretivo.

\subsection{Corretivo}

O calcário usado na neutralização da acidez do solo foi cedido pela empresa Fillercal Rio Formoso LTDA, em Rio Formoso do Araguaia - TO, com PRNT de 102\%. Guimarães (2000), utilizou a mesma fonte de calcário, o qual por ser finamente moído promove rápida neutralização da acidez do solo a partir do quinto dia de incorporação, quando se mantinha o solo umedecido.

As doses utilizadas para elevação da V\% em 70\% nos solos 1 e 2, foram 57 g/caixa e 61 g/caixa, respectivamente.Em função da reatividade do calcário utilizado, após 28 e 60 dias de incubação, foram realizadas amostragens dos solos para análise de rotina, com o objetivo de verificar o efeito do corretivo utilizado. Em virtude da estabilização do $\mathrm{pH}$ e de poucas alterações nos elementos avaliados em ambas amostragens, optou-se pela apresentação da última análise realizada (Tabela 4).

As condições de baixa oxigenação no solo promovem modificações nas suas características químicas, o que necessitou a realização de análises de solo adicionais durante o primeiro e segundo cortes a fim de auxiliar a compreensão sobre as alterações morfofisiológicas e nutricionais encontradas nas espécies estudadas (Tabelas 5 e 6). 
Tabela 4. Análise química dos solos após 60 dias de incubação

\begin{tabular}{|c|c|c|c|c|c|c|c|c|c|c|c|c|c|c|c|c|c|c|}
\hline \multirow[t]{2}{*}{ Solo } & $\mathrm{pH}$ & M. O & $\mathrm{P}$ & $S$ & $\mathrm{~K}$ & $\mathrm{Ca}$ & $\mathrm{Mg}$ & $\mathrm{Al}$ & $\mathrm{H}+\mathrm{Al}$ & SB & $\mathrm{T}$ & $\mathrm{V}$ & $\mathrm{m}$ & B & $\mathrm{Cu}$ & $\mathrm{Fe}$ & $\mathrm{Mn}$ & $\mathrm{Zn}$ \\
\hline & $\mathrm{CaCl}_{2}$ & $\mathrm{~g} \mathrm{dm}^{-3}$ & & $\mathrm{dm}^{-3}$ & \multicolumn{7}{|c|}{$\mathrm{mmol}_{\mathrm{c}} \mathrm{dm}^{-3}$} & & & \multicolumn{5}{|c|}{$\mathrm{mg} \mathrm{dm}^{-3}$} \\
\hline Solo 1 & 6,0 & 22 & 10 & 118 & 2,4 & 37 & 27 & 0 & 22 & 66,4 & 88,4 & 75 & 0 & 0,20 & 0,8 & 250 & 10,7 & 1,9 \\
\hline Solo 2 & 6,5 & 28 & 3 & 149 & 2,7 & 81 & 48 & 0 & 24 & 131,7 & 155,7 & 84 & 0 & 0,35 & 1,4 & 127 & 11,1 & 1,8 \\
\hline
\end{tabular}

Tabela 5. Análise química dos solos no dia do primeiro corte.

\begin{tabular}{|c|c|c|c|c|c|c|c|c|c|c|c|c|c|c|c|c|c|c|}
\hline \multirow[t]{2}{*}{ Solo } & $\mathrm{pH}$ & \multirow{2}{*}{$\begin{array}{l}\text { M.O } \\
\text { g dm }^{-3}\end{array}$} & $\mathrm{P}$ & $\mathrm{S}$ & $\mathrm{K}$ & $\mathrm{Ca}$ & $\mathrm{Mg}$ & $\mathrm{Al}$ & $\mathrm{H}+\mathrm{Al}$ & SB & $\mathrm{T}$ & $\mathrm{V}$ & $\mathrm{m}$ & $B$ & $\mathrm{Cu}$ & $\mathrm{Fe}$ & $\mathrm{Mn}$ & $\mathrm{Zn}$ \\
\hline & $\mathrm{CaCl}_{2}$ & & \multicolumn{2}{|c|}{$\mathrm{mg} \mathrm{dm}^{-3}$} & \multicolumn{7}{|c|}{$\mathrm{mmol}_{\mathrm{c}} \mathrm{dm}^{-3}$} & \multicolumn{2}{|c|}{$\%$} & \multicolumn{5}{|c|}{$\mathrm{mg} \mathrm{dm}^{-3}$} \\
\hline Solo $1 \mathrm{~A}^{(1)}$ & 5,6 & 19 & 16 & 58 & 1,6 & 37 & 31 & 0 & 13 & 69,6 & 82,1 & 84 & 0 & 0,2 & 1,3 & 91 & 13,7 & 0,9 \\
\hline Solo 2 A & 6,1 & 30 & 9 & 111 & 2,4 & 65 & 48 & 0 & 15 & 115,4 & 130,4 & 88 & 0 & 0,2 & 0,3 & 89 & 2,3 & 1,2 \\
\hline Solo $1 \mathrm{Cc}^{(2)}$ & 6,1 & 19 & 14 & 87 & 1,4 & 36 & 28 & 0 & 12 & 65,4 & 77,4 & 84 & 0 & 0,2 & 0,7 & 99 & 4,0 & 0,8 \\
\hline Solo 2 Cc & 6,6 & 29 & 14 & 160 & 2,4 & 69 & 51 & 0 & 14 & 122,4 & 136,4 & 89 & 0 & 0,2 & 0,7 & 47 & 4,0 & 0,8 \\
\hline
\end{tabular}

(1) A = alagamento e (2) Cc = capacidade de campo

Tabela 6. Análise química dos solos no dia do segundo corte.

\begin{tabular}{|c|c|c|c|c|c|c|c|c|c|c|c|c|c|c|c|c|c|c|}
\hline \multirow[t]{2}{*}{ Solo } & $\mathrm{pH}$ & M.O & $\mathrm{P}$ & $\bar{S}$ & $\bar{K}$ & $\mathrm{Ca}$ & $\mathrm{Mg}$ & $\mathrm{Al}$ & $\mathrm{H}+\mathrm{Al}$ & SB & $\mathrm{T}$ & $\mathrm{V}$ & $\mathrm{m}$ & $\mathrm{B}$ & $\mathrm{Cu}$ & $\mathrm{Fe}$ & $\mathrm{Mn}$ & $\mathrm{Zn}$ \\
\hline & $\mathrm{CaCl}_{2}$ & $\mathrm{~g} \mathrm{dm}^{-3}$ & \multicolumn{2}{|c|}{$\mathrm{mg} \mathrm{dm}^{-3}$} & \multicolumn{7}{|c|}{$\mathrm{mmol}_{\mathrm{c}} \mathrm{dm}^{-3}$} & \multicolumn{2}{|c|}{$\%$} & \multicolumn{5}{|c|}{$\mathrm{mg} \mathrm{dm}^{-3}$} \\
\hline Solo $1 \mathrm{~A}^{(1)}$ & 6,0 & 18 & 11 & 55 & 0,5 & 36 & 31 & 0 & 14 & 67,5 & 81,6 & 84,5 & 0 & 0,16 & 0,6 & 238 & 5,2 & 1,1 \\
\hline Solo 2 A & 6,5 & 25 & 5 & 41 & 1,5 & 51 & 60 & 0 & 16 & 112,5 & 128,5 & 87,5 & 0 & 0,3 & 1,7 & 264 & 15,1 & 0,8 \\
\hline Solo $1 \mathrm{Cc}^{(2)}$ & 6,6 & 19 & 11 & 72 & 0,6 & 35 & 29 & 0 & 12 & 64,6 & 76,6 & 84,3 & 0 & 0 & 0,4 & 110 & 1,7 & 0,9 \\
\hline Solo 2 Cc & 6,6 & 29 & 6 & 240 & 1,3 & 48 & 62 & 0 & 13 & 111,3 & 124,3 & 89,5 & 0 & 0,3 & 0,8 & 56 & 4,7 & 1,2 \\
\hline
\end{tabular}

(1) A = alagamento e (2) Cc = capacidade de campo 
Baseados nos resultados da análise química após a incubação do corretivo, aplicou-se a quantidade de fósforo equivalente a 40 e $96 \mathrm{mg} \mathrm{kg}^{-1}$ de solo (solo 1 e solo 2 respectivamente) na forma de super triplo (elevando-se a teores de $15 \mathrm{mg} \mathrm{dm}^{-3}$ ). Para as adubações nitrogenada e potássica, as quantidades aplicadas foram $900 \mathrm{mg} \mathrm{kg}^{-1}$ de solo (50 kg de $\mathrm{N} \mathrm{ha}^{-1}$ ) e $600 \mathrm{mg} \mathrm{kg}^{-1}$ de solo (30 kg de $\mathrm{K}_{2} \mathrm{O}$ ), utilizando-se uréia e cloreto de potássio como fontes, respectivamente. Todos os nutrientes foram diluídos em 500 ml/caixa e aplicados na forma de soluções aquosas. As aplicações de nitrogênio foram parceladas a cada corte, sendo a primeira aplicação 15 dias após o plantio, enquanto a potássica apenas após cada corte.

\subsection{Obtenção de mudas}

As espécies forrageiras utilizadas no presente experimento foram a Brachiaria mutica (Forsk) Stapf e a Echinochloa polystachya (H.B.K.) Hitch, as quais somente se reproduzem por meio vegetativo.

O material vegetativo usado foi proveniente de canteiros existentes, plantados desde 1998, em área próxima ao Departamento de Produção Animal da ESALQ. Ambas as espécies constituíam-se de uma fração de haste madura de aproximadamente 5 - 7 cm, contendo de uma a duas gemas.

\subsection{Esquema do experimento}

A estrutura para execução do experimento foi composta de 32 caixas plásticas de 25 x 32,5 x 46,5 cm (38 l) para acondionamento do solo; três caixas plásticas de 25 x 32,5 x 46,5 cm (38 l) e três caixas de 58 x 55 x 92,5 cm (300 l) como reservatórios de água; além de tubulações de PVC para distribuição de água. A estrutura foi baseada no modelo descrito por Platzeck (1989).

As 32 caixas plásticas (38 l), denominadas de unidades experimentais, foram montadas sobre quatro bancadas, sendo que cada bancada possuía oito unidades experimentais. Os reservatórios de água ficaram sobre uma quinta bancada, onde através 
de bóias, os reservatórios de $300 \mathrm{l}$ mantinham sempre cheios os de $38 \mathrm{l}$ (Figuras 2 a 4).

Essas caixas, que funcionavam como reservatório, constituiam um sistema de vasos comunicantes que abasteciam por gravidade cada condição de umidade do solo: o excesso de umidade (alagamento) e a capacidade de campo de cada solo (solos 1 e 2), em função dos resultados da análise física apresentados na Tabela 1. Os reservatórios de água eram abastecidos em períodos de 5 a 7 dias por meio de uma mangueira plástica conectada à rede de abastecimento de água.

Utilizou-se no fundo de cada caixa uma camada de $5 \mathrm{~cm}$ de pedriscos para facilitar a entrada e drenagem do excesso de água, e uma tela de sombrite sobre a camada, para evitar a passagem do solo e raízes causando possíveis entupimentos na tubulação.

Foi instalado um higrômetro e um termômetro para controle da umidade e temperatura ambiente, haja vista, que havia variação da temperatura de até $20^{\circ} \mathrm{C}$, ocorrendo temperaturas máximas de $40^{\circ} \mathrm{C}$ durante o período do experimento. Em virtude das constantes elevações de temperaturas e decréscimos na umidade relativa do ar (abaixo de 35\%), o piso da casa de vegetação era molhado, bem como utilizava-se de abertura e fechamento das cortinas laterais e do lanternin da casa de vegetação, a fim de melhorar as condições climáticas para o crescimento e desenvolvimento das espécies em estudo.

A irrigação para as unidades experimentais sob capacidade de campo, era realizada pelo sistema de abastecimento, por meio da abertura e fechamento de registros, em função das leituras dos tensiômetros (0,01 bar para solo1 e 0,03 bar para solo 2), instalados aleatoriamente a $10 \mathrm{~cm}$ de profundidade, enquanto que nas unidades experimentais que sofreram inundação, a irrigação era controlada visualmente (Figuras 5 e 6). 

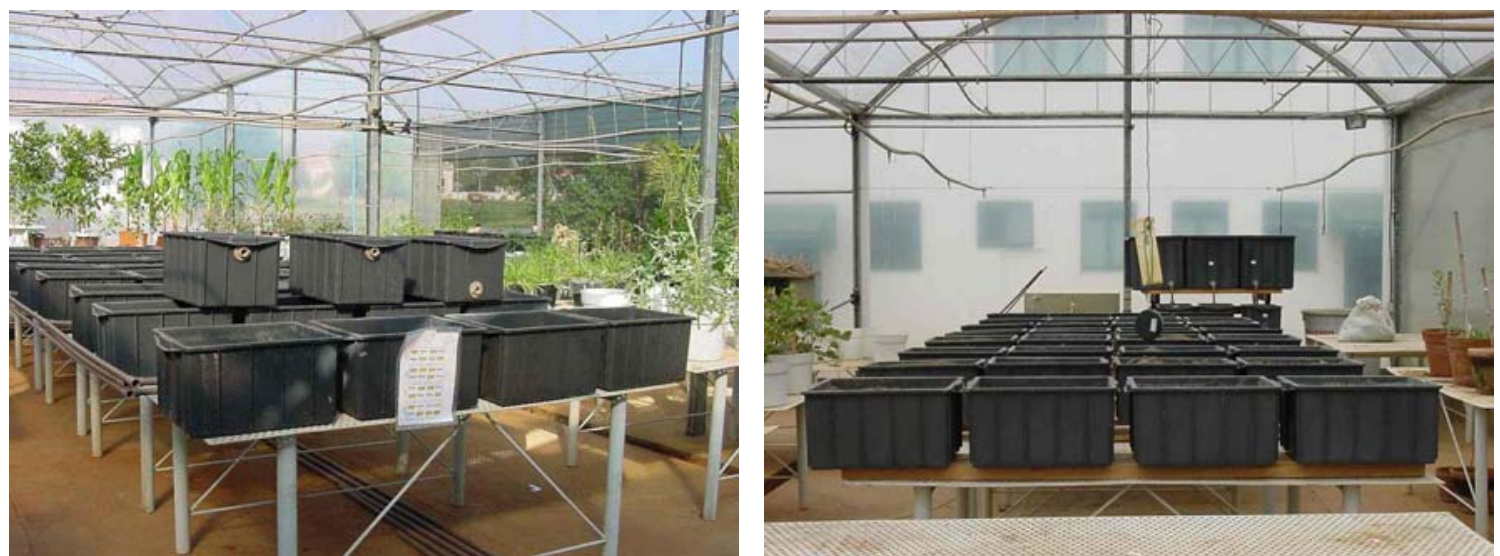

Figura 2 - Caixas abastecedoras de água
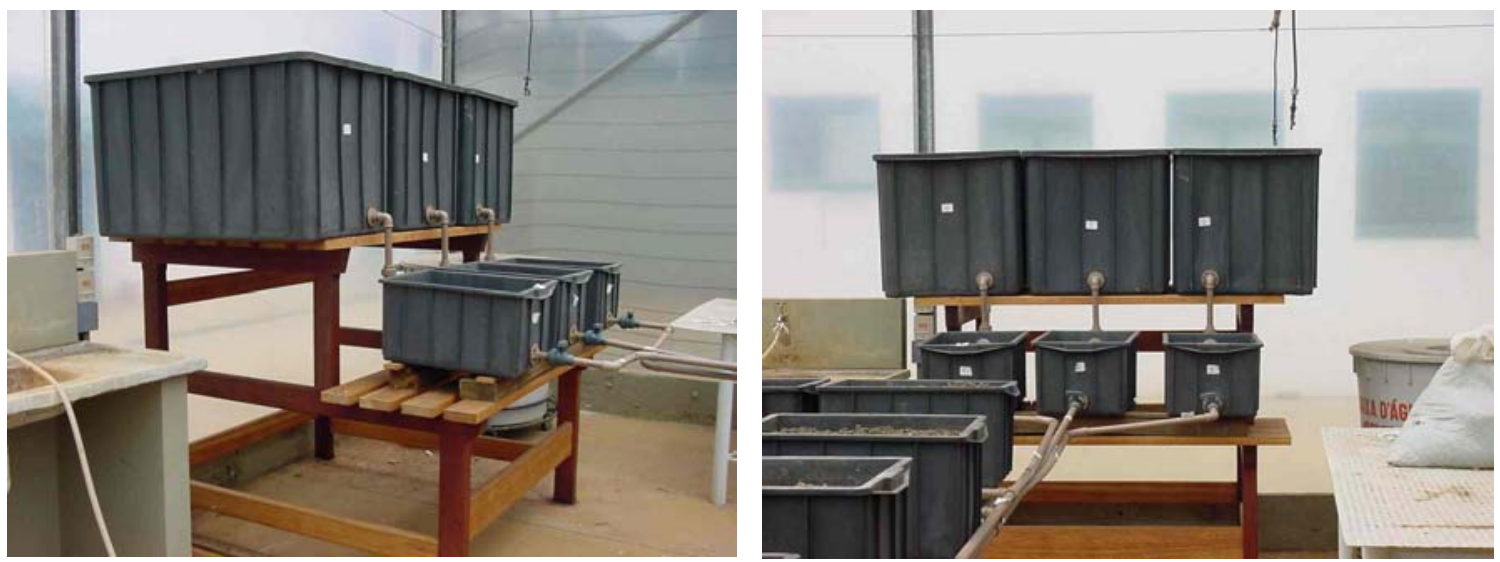

Figura 3 - Tubulações e distribuição de água para as bancadas
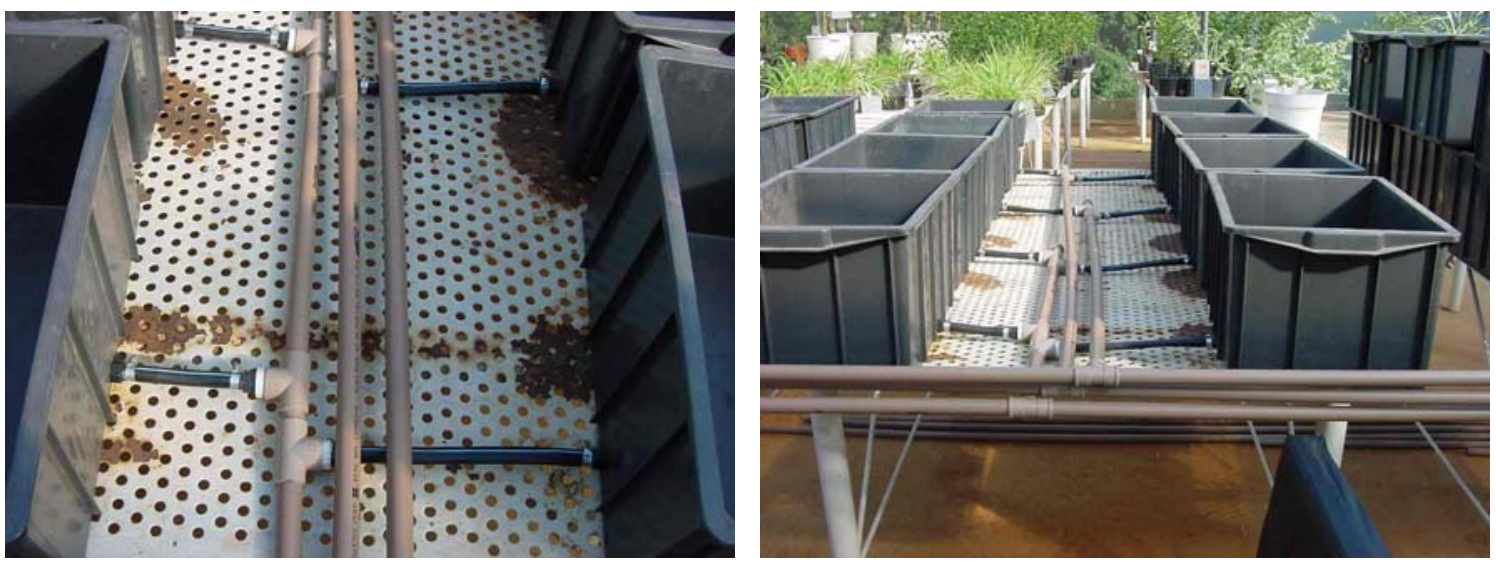

Figura 4 - Caixas de 351 com suas respectivas tubulações e conexões 


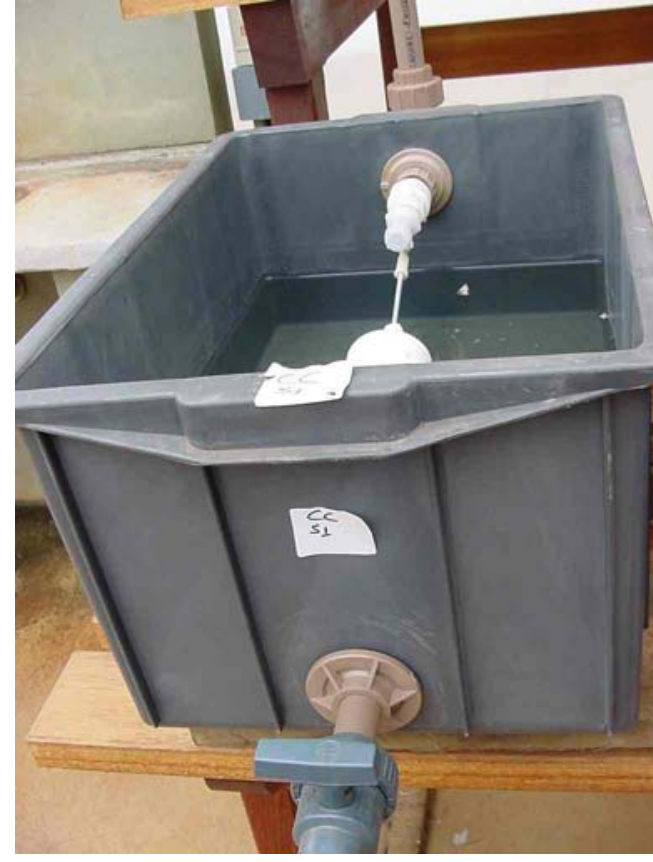

Figura 5 - Detalhes da bóia e registro para controle do fornecimento de água

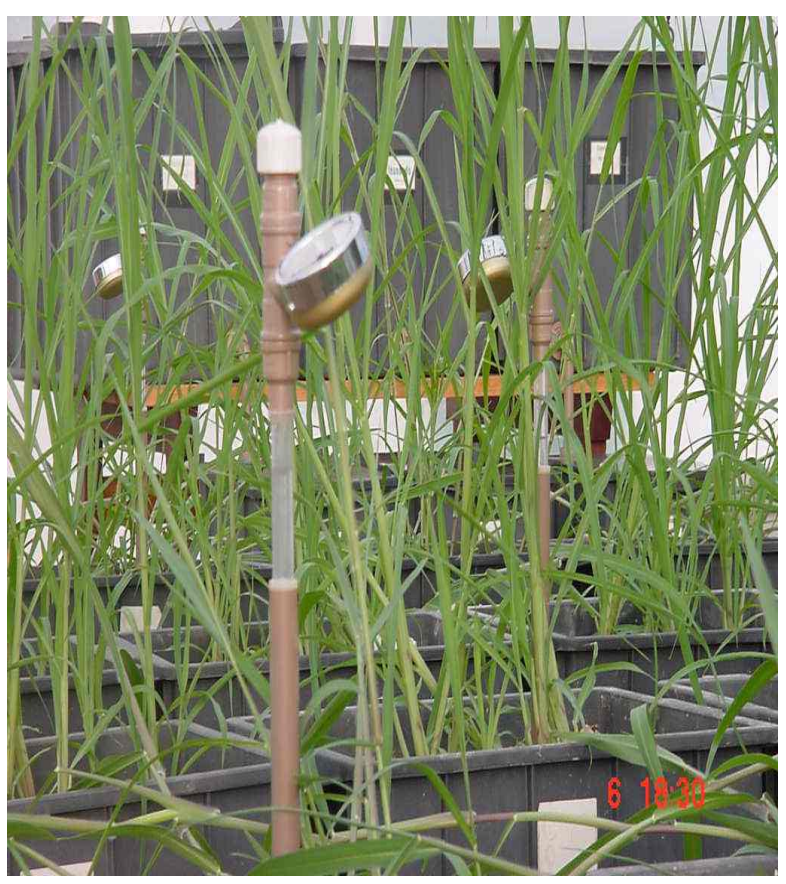

Figura 6 - Tensiômetros instalados para controle de umidade do solo nas unidades em capacidade de campo

\subsection{Delineamento experimental}

O modelo experimental adotado foi o delineamento de parcelas subdivididas com um arranjo fatorial 2 × 2 nas subparcelas, apresentando como repetições quatro blocos casualizados. Foram consideradas como parcelas, as condições de umidade (excesso hídrico e capacidade de campo), as sub-parcelas a combinação entre dois capins e dois solos, totalizando 32 unidades experimentais.

Os tratamentos foram constituídos de:

Tratamento 1: Brachiaria mutica + Solo $1+$ condição de umidade 1 (excesso hídrico)

Tratamento 2: Brachiaria mutica + Solo 2 + condição de umidade 1

Tratamento 3: Echinochloa polystachya + Solo 1 + condição de umidade 1

Tratamento 4: Echinochloa polystachya + Solo 2 + condição de umidade 1 
Tratamento 5: Brachiaria mutica + Solo 1 + condição de umidade 2 (capacidade de campo)

Tratamento 6: Brachiaria mutica + Solo 2 + condição de umidade 2

Tratamento 7: Echinochloa polystachya + Solo 1 + condição de umidade 2

Tratamento 8: Echinochloa polystachya + Solo 2 + condição de umidade 2

\subsubsection{Preparação e plantio}

Após os 60 dias de incubação dos solos, foram plantadas estacas de ambas as espécies, totalizando 12 estacas por caixa. Paralelamente ao experimento, foram mantidas quatro bandejas com mudas das espécies, para fins de reposição ou substituição em cada uma das unidades experimentais (Figuras 7 e 8).

Durante 20 dias foram realizados desbastes e transplantes de mudas, em todo o experimento objetivando assegurar a uniformização do estande dentro de cada unidade experimental. Decorrido o tempo necessário e verificação de que todo o experimento apresentava bom estabelecimento das mudas, foi realizado um desbaste deixando somente oito plantas por unidade experimental. 

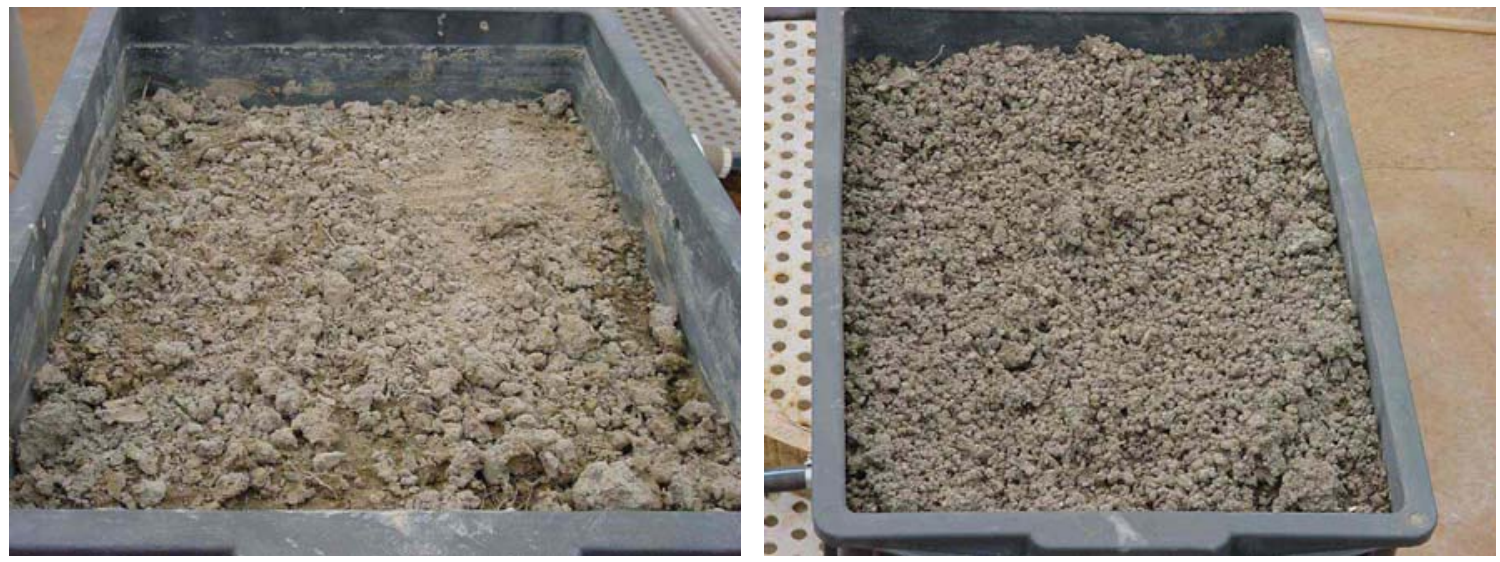

Figura 7 - Solo 1 e 2 respectivamente, 60 dias após a incorporação do calcário prontos para o plantio
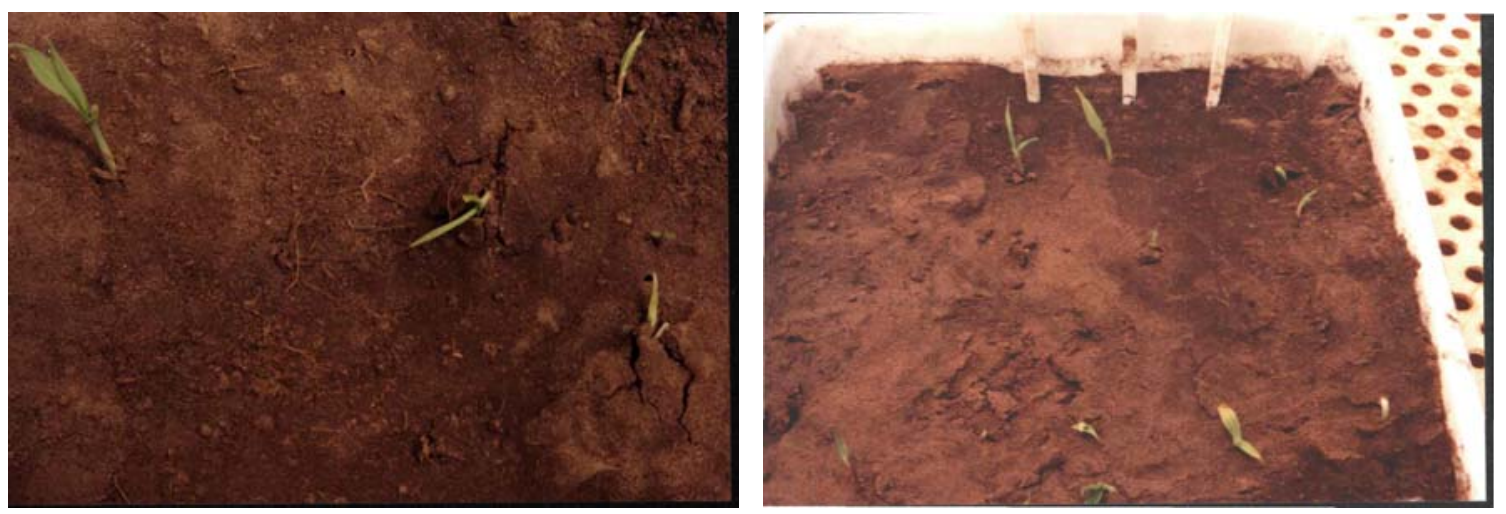

Figura 8 - Mudas de Echinochloa polystachya e Brachiaria mutica respectivamente, aos 10 dias de crescimento cultivadas, em bandejas

\subsubsection{Condução do experimento}

Depois do desbaste aos 28 dias de crescimento, avaliou-se o experimento por meio da contagem do número de perfilhos por unidade experimental, e da determinação da taxa fotossintética de folhas recém expandidas, em plantas escolhidas ao acaso. Após a avaliação geral, as espécies foram cortadas a partir de $5 \mathrm{~cm}$ do solo como corte de uniformização. Após o corte de uniformização foi realizada uma adubação nitrogenada equivalente a $450 \mathrm{mg} \mathrm{kg}^{-1}$ de solo (25 kg de $\mathrm{N} \mathrm{ha}^{-1}$ ) em todas as unidades experimentais, para assegurar o bom desenvolvimento da rebrota. 
No dia posterior a adubação deu-se início a inundação das 16 unidades experimentais. As avaliações foram iniciadas após a inundação das unidades experimentais (Figuras 9 e 10).

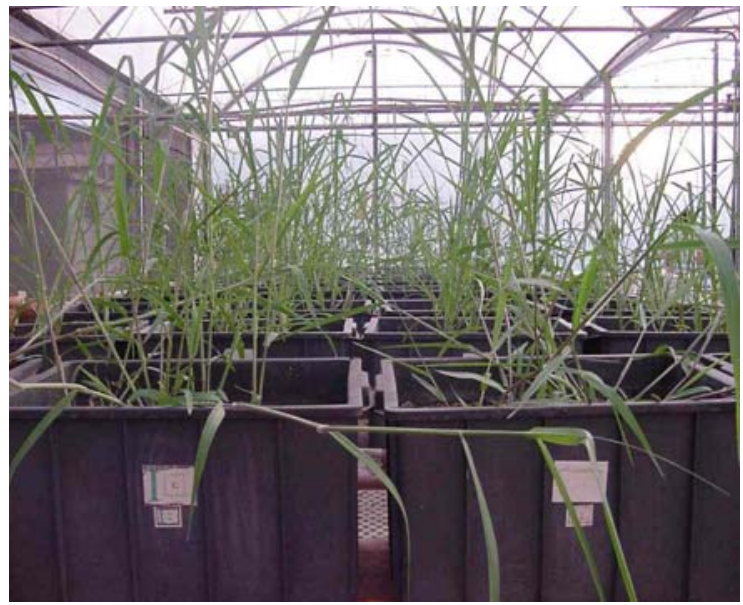

Figura 9 - Experimento um dia antes do corte de uniformização

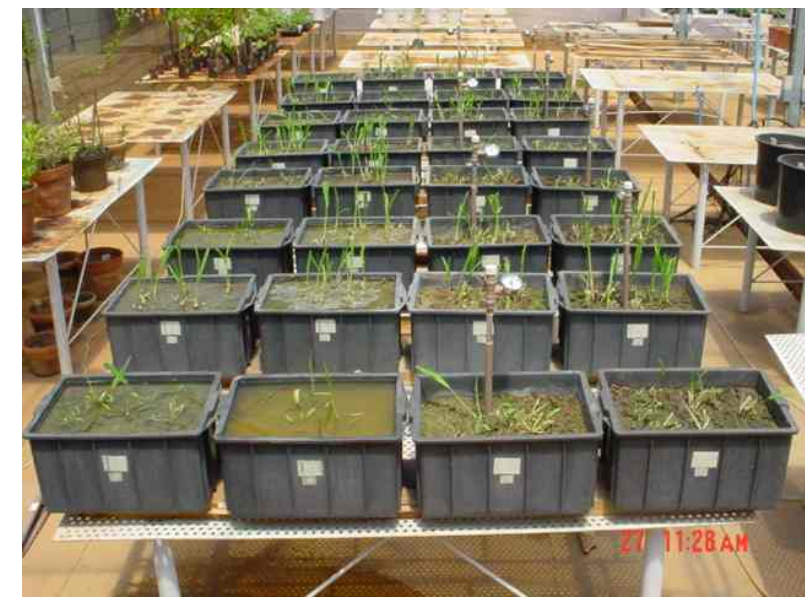

Figura 10 - Experimento após o corte de uniformização e imposição dos tratamentos em estudo

De acordo com o delineamento do experimento, foram inundadas as 16 unidades com uma lâmina de água de $5 \mathrm{~cm}$, ocorrendo submersão de algumas plantas. A lâmina de água era monitorada diariamente para que permanecesse constante durante todo experimento, utilizando-se uma régua devidamente marcada.

O experimento recebeu controle de pragas, devido ao aparecimento de pulgões, formigas e trips, por meio da aplicação em aspersão de inseticida Deltametrina, $(0,0048$ ml kg de solo) assim como, o uso de um algicida, aplicando-se por meio de conta gotas, uma gota por unidade experimental inundada e nos reservatórios, devido o crescimento acelerado de algas sobre a superfície da água. 


\subsubsection{Parâmetros analisados}

Baseados nos objetivos do presente estudo, os quais foram de avaliar o desempenho das duas espécies de gramíneas tropicais consideradas tolerantes ao excesso hídrico, cultivadas em dois solos quando submetidas a diferentes condições de umidade, de verificar nos solos qual a melhor resposta em termos de produção de matéria seca e qualidade da forragem, os parâmetros analisados foram:

1 - Parâmetros morfofisiológicos:

a) Taxas de fotossíntese foliar e condutância estomática;

b) Atividade da álcool desidrogenase;

c) Número de perfilhos totais;

d) Produção de matéria seca da parte aérea (lâmina, haste e material morto) ;

e) Área foliar;

f) Relação folha:haste;

g) Produção de raízes adventícias;

h) Produção de matéria seca do sistema radicular;

i) Análise nutricional da parte aérea da planta (macro e microminerais);

j) Análise bromatológica: FDN, FDA e lignina.

2 - Parâmetros relacionados à característica química dos solos estudados:

a) Temperatura do solo;

b) Estimativa de $\mathrm{pH}$ e Eh (pontencial redox);

c) Análises de fertilidade do solo.

- Parâmetros morfofisiológicos:

As taxas de fotossíntese foliar e condutância estomática foram determinadas usando-se um medidor portátil modelo LI - 6400 (LI-COR, Lincoln Nebraska, EUA). Trata-se de um sistema portátil, com bateria interna própria, que permite ao operador leituras instantâneas de fotossíntese, condutância estomática, temperatura da folha e luz incidente interceptada por área foliar. Foram realizadas 32 medições em cada data de 
amostragem (1 planta x 1 folha jovem recém-expandida) medidas em diferentes estádios de desenvolvimento.

As taxas de fotossíntese e condutância estomática foram obtidas em função de diferentes densidades de fluxo de fótons fotossintéticos (DFFF) de: 0, 30, 100, 500, 1000, 1800 e $2000 \mu \mathrm{mol} \mathrm{m} \mathrm{m}^{-1}$.

As respostas das curvas de fotossíntese líquidas obtidas em função da luz foram ajustadas de acordo com a equação descrita por Prado e de Moraes (1997):

$$
\mathrm{A}=\mathrm{A}_{\text {máx }}\left[1-\mathrm{e}^{-\mathrm{k}(\mathrm{Q}-\mathrm{Qc})}\right]
$$

onde $\mathbf{A}_{\text {máx }}$ é a taxa de fotossíntese máxima; $\mathbf{k}$ é a constante de ajuste; $\mathbf{Q}$ é a densidade de fluxo de fótons fotossintéticos (DFFF) e Qc é o ponto de compensação luminosa.

O ajuste das curvas de resposta de fotossíntese líquida, com base na equação descrita, foi realizado pelo programa estatístico Origin 7.0 (OriginLab Inc., Northampton, USA).

Efetuaram-se avaliações prévias para estimar o tempo necessário gasto em cada unidade experimental para determinação das taxas fotossintéticas. Eram realizadas oito medidas de fotossíntese foliar e condutância estomática por dia, em virtude da duração de 40 a 50 minutos por unidade experimental (tratamento). Antes de iniciar as medições, aplicava-se quatro intensidades de radiação diferentes (500, 1000, 1500 e $2000 \mu$ mol fóton $\mathrm{m}^{-1} \mathrm{~s}^{-1}$ ), para evitar os efeitos de quantidade e qualidade da radiação incidente dentro da casa de vegetação, e assim estimular o aparato fotossintético contido nas folhas avaliadas.

As medições iniciavam-se por volta das 8:00 horas da manhã e encerravam-se às 12:00 horas. O fato de a primeira avaliação iniciar antes do horário mais adequado fisiologicamente (9:00 horas) foi devido à demora em cada avaliação, descrita anteriormente.

As amostras para determinação da atividade álcool desidrogenase (ADH), provenientes das plantas cultivadas submetidas à inundação, foram realizadas em duas etapas, no laboratório de Genética e Bioquímica de Plantas da ESALQ.

Etapa I - Obtenção do extrato enzimático:

As amostras de tecido radicular foram retiradas através de uma sonda de aço 
inoxidável de $4 \mathrm{~mm}$ de diâmetro alcançando o fundo das caixas (aproximadamente 20 cm). O material coletado (solo + raiz) foi acondicionado em sacos plásticos e armazenados em freezer a $-20^{\circ} \mathrm{C}$ no laboratório de Plantas Forrageiras da ESALQ, para posterior análise.

De acordo com o protocolo descrito por Tribuzy (1998), para a obtenção dos extratos, o material em estudo (raiz) deveria ter sido lavado, pesado, colocado em papel alumínio, congelado em nitrogênio líquido e, posteriormente em freezer de $-80^{\circ} \mathrm{C}$, temperatura adequada para a redução do metabolismo celular, até o momento das análises. Entretanto, o material coletado no experimento foi armazenado em temperaturas maiores devido a ausência de estrutura adequada no momento da coleta.

As amostras de solo foram descongeladas lentamente em caixas térmicas com gelo para a retirada de raiz e, em seguida, lavadas com água destilada sob baixa temperatura, e colocadas em copos plásticos dentro de caixas térmicas com gelo. Antes da pesagem do tecido (500 mg), usou-se papel absorvente para retirada da umidade.

O extrato enzimático bruto foi obtido através da fragmentação das amostras de tecido radicular, em $2 \mathrm{ml}$ de um meio de extração composto de tampão fosfato de

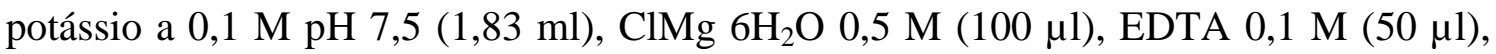
DTT 1,0M (10 $\mu$ l), PMSF 0,4 M (10 $\mu \mathrm{l})$ e PVPP (100 mg). As amostras foram colocadas em tubos falcon de $10 \mathrm{ml}$ e submetidas a uma centrifugação de 10.000 rpm durante 30 minutos a $4^{\circ} \mathrm{C}$.

Os extratos obtidos foram armazenados em freezer a $-20^{\circ} \mathrm{C}$ até serem utilizados no ensaio enzimático.

Etapa II - Ensaio enzimático:

Foram adicionados $50 \mu \mathrm{l}$ do extrato enzimático em 1,35 ml do meio de reação composto de tampão Tris+HCl 50 mM pH 8,9 e DTT 2 mM, $50 \mu$ de etanol e $50 \mu l$ de $\mathrm{NAD}+7,5 \mathrm{mM}$, incubando-se a mistura durante 30 minutos a $30^{\circ} \mathrm{C}$. O NADH+H produzido foi determinado pela leitura em espectrofotômetro a $340 \mathrm{~nm}$, e os resultados expressos por unidade de proteína de raiz quantificada segundo Bradford (1976). Para a quantificação de proteína de raiz foi necéssário adiconar $20 \mu \mathrm{l}$ do extrato enzimático em 
1 ml de solução de Bradford em cubetas, e em seguida colocadas em espectrofotômetro para leitura a $595 \mathrm{~nm}$.

O número de perfilhos foi determinado após o estabelecimento do estande com 8 plantas. Antes de cada corte procedeu-se a contagem dos perfilhos basais.

Foram realizados dois cortes no decorrer do experimento: o primeiro corte 30 dias após o corte de uniformização, e o segundo, 35 dias após o primeiro. A cada corte, todo material colhido era separado em lâminas foliares, haste (colmo+bainha) e material morto. Ao final do segundo corte também foi separado o sistema radicular.

As lâminas foliares assim que colhidas eram medidas utilizando-se um medidor de área foliar LAI 3100 (LI-COR, Lincoln Nebraska, EUA) (Figuras 11 e 12).

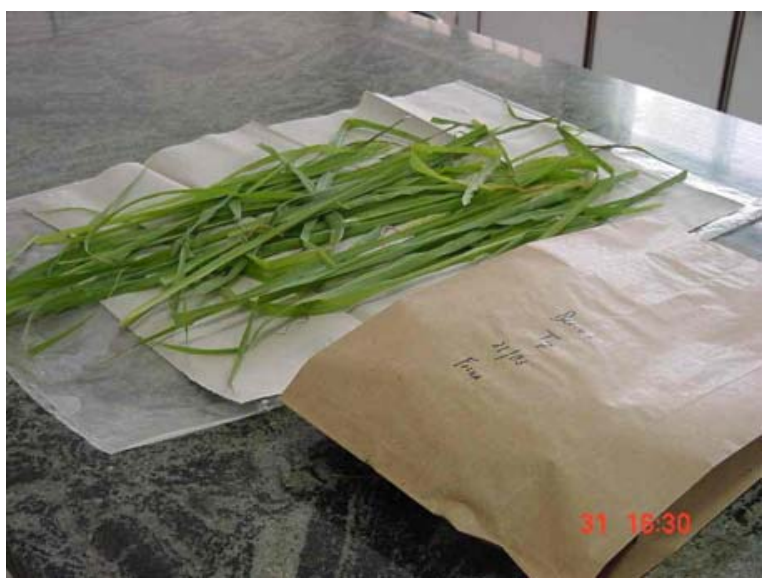

Figura 11 - Lâminas foliares após o corte

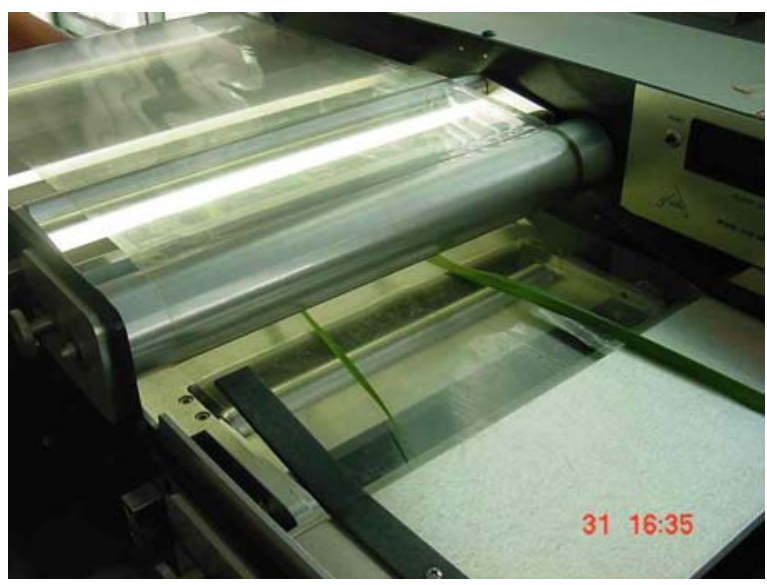

Figura 12 - Medidor de área foliar LAI 3100

O sistema radicular foi lavado com auxílio de um jato de água manual aplicado sobre o bloco de solo + raiz formada.

A matéria seca de cada componente da planta foi obtida por secagem do material a $65^{\circ} \mathrm{C}$ por 72 horas, em estufa de circulação de ar forçada. Para cada componente seco, apenas as lâminas foliares foram moídas em moinho tipo "Willey", passando em peneira de malha de $1 \mathrm{~mm}$ e acondicionadas em sacos plásticos para em seguida serem encaminhadas para análise. 
O desenvolvimento de raízes adventícias foi avaliado por meio de um "score” de notas de 0 a 4 ( nenhum, 25, 50, 75 e 100\%, respectivamente), o que correspondia uma escala de menor a maior produção de raízes por unidade experimental.

No laboratório de Solos e Nutrição de Plantas da ESALQ foram realizadas as análises de macro (N, P, K, Ca, Mg e S) e microminerais (Zn, Cu, Fe, Mn e B). O N foi determinado pelo método de Kjedahl, enquanto que $\mathrm{P}, \mathrm{K}, \mathrm{S}, \mathrm{Ca}, \mathrm{Mg}, \mathrm{Cu}, \mathrm{Fe}, \mathrm{Mn}$, e Zn por meio de extrato obtido da digestão nitro-perclórica das amostras. O P foi determinado colorimetricamente; K por fotometria de chama; $\mathrm{Ca}, \mathrm{Mg}, \mathrm{S}, \mathrm{Cu}, \mathrm{Fe}, \mathrm{Mn}$ e Zn por espectrofotometria de absorção atômica de acordo com Sarruge e Haag (1974). B foi determinado pelo método colorimétrico-azometina-H (Bataglia et al., 1983).

As análises bromatológicas para matéria seca definitiva a $105^{\circ} \mathrm{C}$, matéria mineral de acordo com o A.O.A.C (1995), fibra em detergente neutro (FDN), fibra em detergente ácido (FDA) e lignina, foram realizadas no laboratório de Bromatologia da ESALQ. Os teores de FDN, FDA e lignina foram obtidos pelo método de Goering e Van Soest (1970).

- Parâmetros relacionados à característica química dos solos estudados:

As variáveis relacionadas as alterações químicas ocorridas no solo, pH e Eh, foram determinadas por meio de um pHgâmetro utilizando-se eletrodos específicos para leituras de pH e Eh, localizado no laboratório próximo a casa-de-vegetação. As leituras eram realizadas a cada três dias, no intuito de monitorar as mudanças ocorridas envolvendo ambiente de pouca oxigenação. Para a realização dessas leituras, realizaramse amostragens com auxílio de um tubo de aço inox (2 cm de diâmetro), a uma profundidade de $15 \mathrm{~cm}$, uma seringa plástica para retirada da água das unidades, e copos descartáveis para o acondicionamento do solo para posterior leitura (Figura 13).

No laboratório, as amostras eram agitadas lentamente, seguido da colocação do eletrodo dentro de cada copo (Figura 15a).

A temperatura do solo era determinada antes das amostragens de solo com o uso de um termopar, o qual permaneceu ligado durante o transcorrer do experimento. As 
medidas de temperatura eram obtidas automaticamente após a inserção do termopar a 5 cm de profundidade, em cada unidade experimental submetida a inundação. Foram obtidas medidas de temperatura, ao acaso, de unidades experimentais sob capacidade de campo somente como averiguação (Figura 15b).

As análises de fertilidade do solo foram feitas durante o experimento, por meio de coletas de solo efetuadas antes do primeiro corte, entre o primeiro e o segundo, e após o segundo corte, a fim de verificar possíveis alterações químicas ocorridas. As amostras foram encaminhadas ao laboratório de Solos e Nutrição de Plantas da ESALQ para as seguintes determinações: $\mathrm{pH}$ em $\mathrm{CaCl}_{2} \quad$ 0,01 M (1:2,5); matéria orgânica; macronutrientes ( $\mathrm{P}, \mathrm{K}, \mathrm{Ca}, \mathrm{Mg}, \mathrm{SO}_{4}{ }^{2-}$ e $\mathrm{Na}$ ); micronutrientes ( $\mathrm{Zn}, \mathrm{Cu}, \mathrm{Fe}, \mathrm{Mn}$ e B); $\mathrm{H}+\mathrm{Al} \mathrm{e} \mathrm{Al}^{3+}$. 

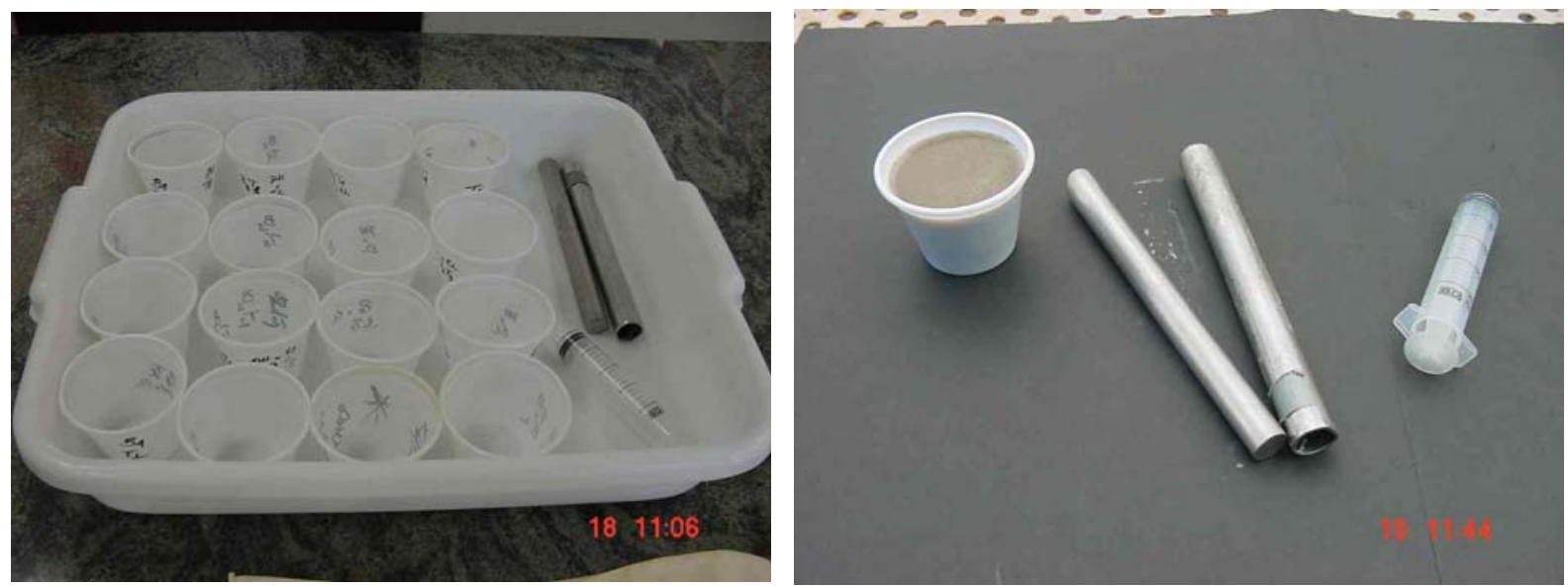

Figura 13 - Material usado na coleta de solo para leituras de pH e Eh
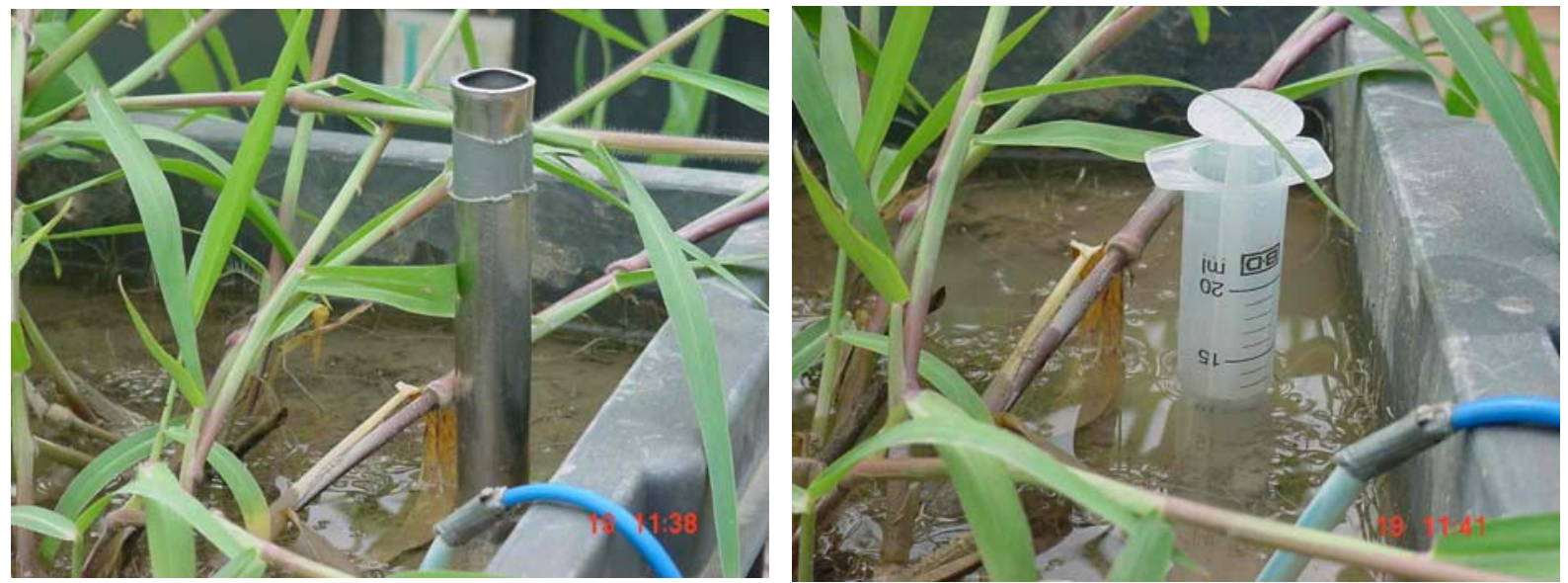

Figura 14 - Sonda, seringa para retirada de água uso de termopar ( fio azul)
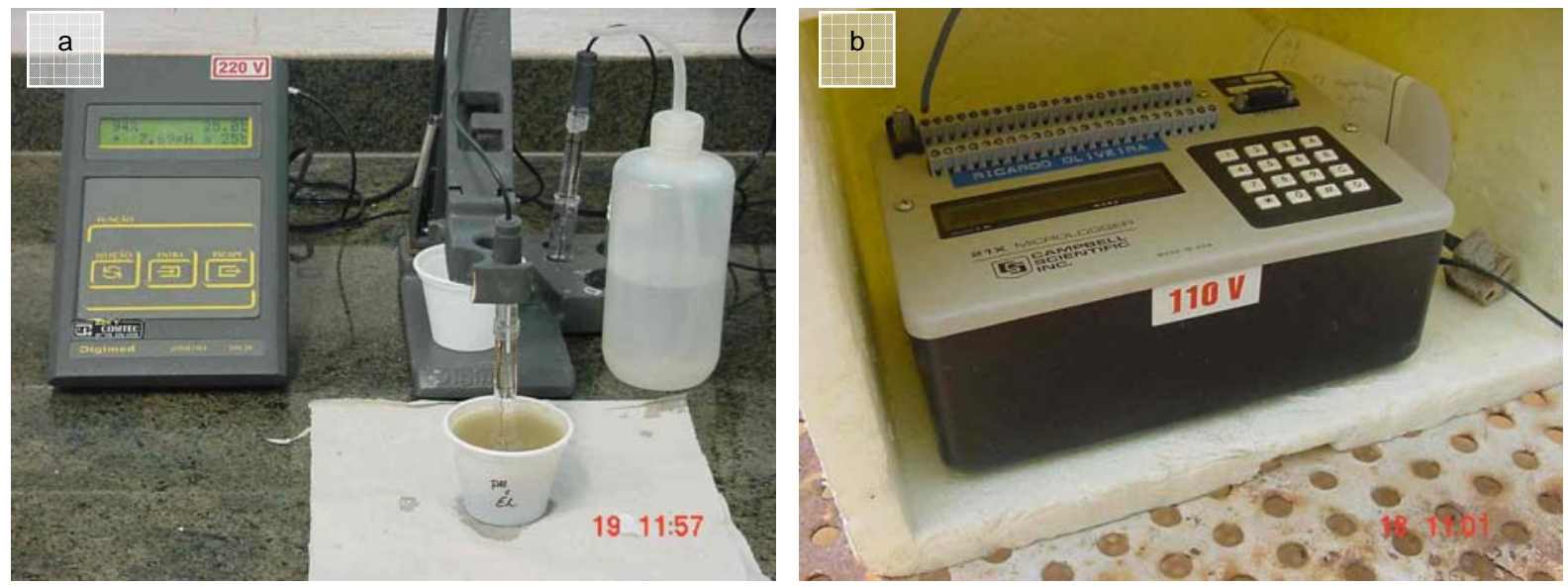

Figura 15 - pHgâmetro para leituras de pH e Eh e armazenador de dados usado para os registros de temperatura do solo 


\subsection{Análises estatísticas}

Os dados foram analisados seguindo a estrutura do delineamento adotado de parcelas subdividida com um arranjo fatorial 2 × 2 nas subparcelas e blocos como repetições.

As análises foram realizadas por procedimentos GLM e Mixed do pacote estatístico do SAS (SAS Institute, 1998), além de análises de medidas repetidas (comando “ repeated” - proc Mixed ) para as variáveis de solo como temperatura, pH e Eh. Para todas as análises, foi averiguado a homogeneidade de variâncias, a normalidade dos dados e a transformação de algumas variáveis como FDN, FDA e Zn. Foi considerado como nível de significância 5\% de probabilidade. 


\section{RESULTADOS E DISCUSSÃO}

\subsection{Características morfofisiológicas}

\subsubsection{Fotossíntese}

As taxas de fotossíntese líquida máxima ( $\left.\mathrm{A}_{\text {máx }}\right)$ não diferiram entre tratamentos estudados $(\mathrm{P}>0,05)$, apesar de apresentar em significância para ponto de compensação luminoso (Qc) entre espécies, conforme observados na Figura 16 e Tabela 7, respectivamente.

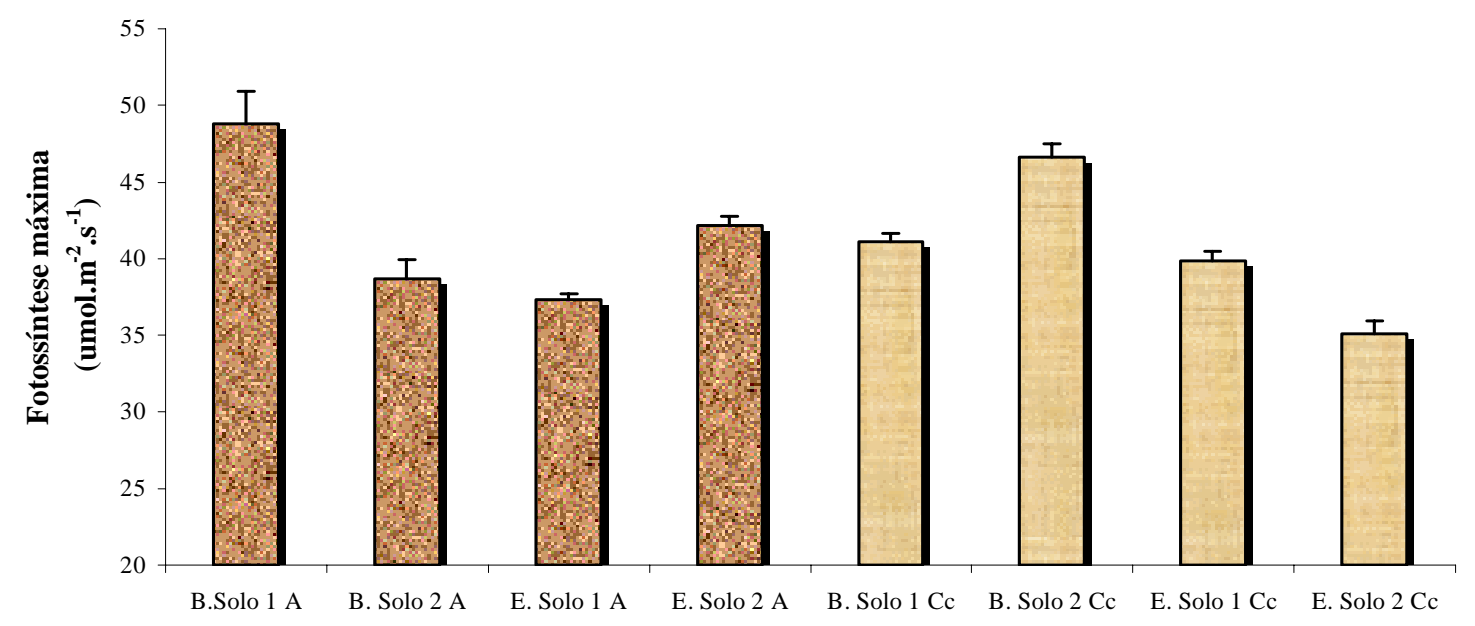

Figura 16 - Média dos valores de fotossíntese líquida máxima $\left(\mathrm{A}_{\text {máx }}\right)$ em relação aos tratamentos analisados $(\mathrm{B}=$ B. mutica; $\mathrm{E}=$ E. polystachya; $\mathrm{A}=$ alagamento; $\mathrm{Cc}=$ Capacidade de campo)

O ponto de compensação de luz (Qc) observado para B.mutica em relação à $E$. polystachya foi menor, indiferente dos tipos de solo e condições de umidade, o que provavelmente está associado a uma menor respiração, maior fixação de $\mathrm{CO}_{2}$ e eficiência do processo de carboxilação (Tabela 7). Observa-se que os tratamentos sob 
alagamento relacionados a $B$. mutica, apresentam maiores Qc em relação à capacidade de campo (Figura 17), no entanto, esses valores encontram-se entre $20-50 \mu \mathrm{mol} \mathrm{m}{ }^{-2} \mathrm{~s}^{-1}$, citados por Lacher (1994) para plantas $\mathrm{C}_{4}$.

Tabela 7. Média dos valores do ponto de compensação de luz (Qc) em função dos capins cultivados

\begin{tabular}{|c|c|}
\hline Capins & Qc $\left(\mu \mathrm{mol} \mathrm{m} \mathrm{m}^{-2} \mathrm{~s}^{-1}\right)$ \\
\hline Brachiaria mutica & $36,68 \mathrm{~b}$ \\
\hline Echinochloa polystachya & $45,18 \mathrm{a}$ \\
\hline
\end{tabular}

As espécies apresentaram respostas semelhantes em ambas condições de umidade, tanto para taxa de fotossíntese líquida (A) quanto para condutância estomática (Gs) com uma correlação positiva entre as variáveis, onde a fotossíntese aumenta a medida em que aumentam os valores de condutância (Figuras 17 e 18).

O alagamento não influenciou a redução de A nem de Gs dos capins. Resultados semelhantes foram obtidos por Baruch (1994) estudando as mesmas espécies em que a A e Gs não diminuiriam sob condição de anoxia, em virtude dos capins serem tolerantes, o que é atribuído ao suprimento de oxigênio para as raízes por meio da combinação do desenvolvimento rápido e extensivo de raízes adventícias, formação de espaços aerenquimatosos e hábito de crescimento (estolonífero), os quais contribuíram para manter a atividade do sistema radicular como forma de compensar a redução da concentração de oxigênio no solo (Figuras 17 e 18).

De acordo com Jackson e Drew (1984), Baruch e Mérida (1985) e Crawford (1992) essas respostas morfofisiológicas são típicas de plantas de ambientes alagadiços, embora mesmo essas espécies tolerantes sofram com decréscimos na produção total de massa seca.

O tipo de solo em que se cultivou a $B$. mutica sob alagamento, também parece não ter influenciado nas taxas fotossintéticas e condutância estomática da espécie. 


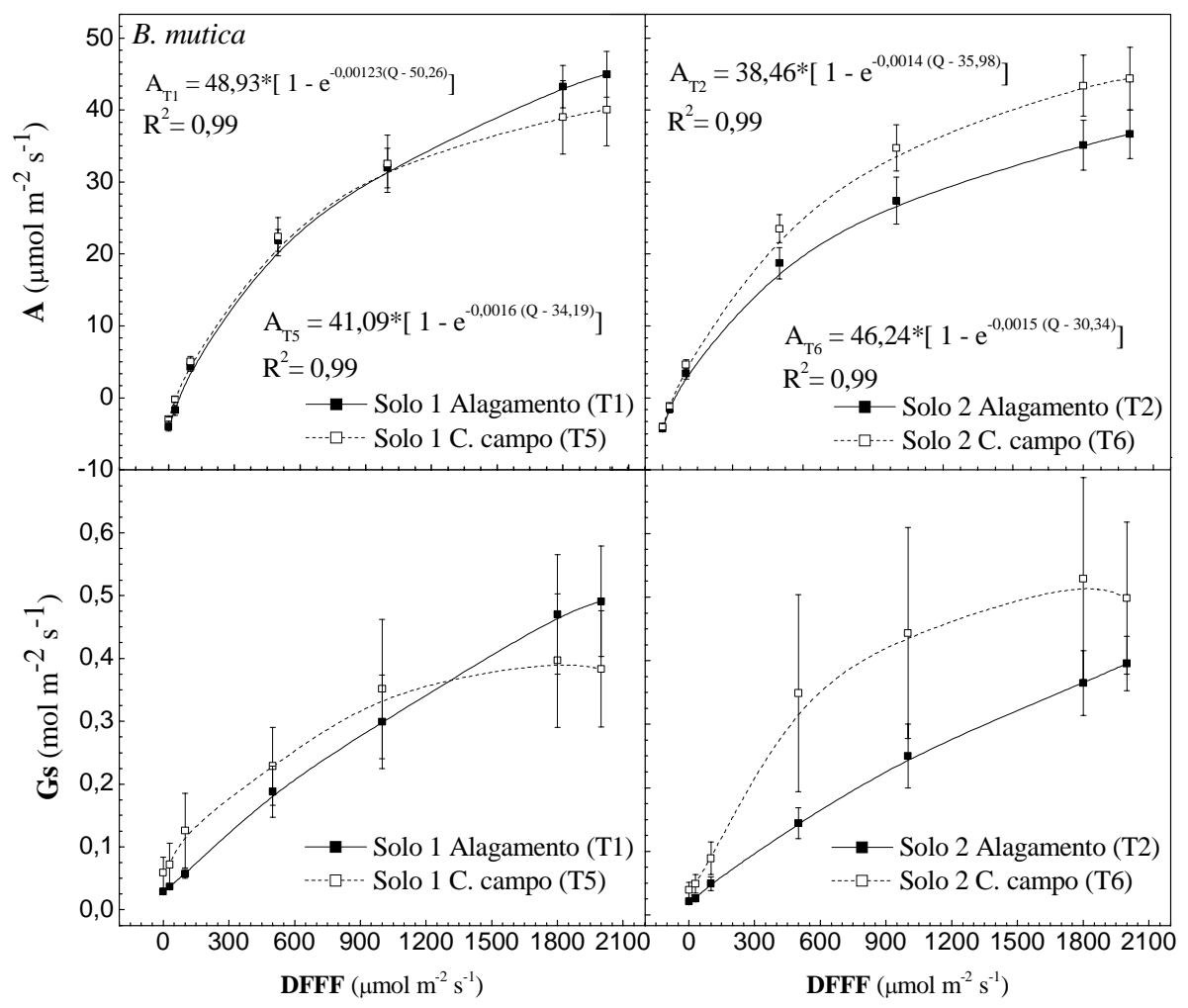

Figura 17 - Taxas de fotossíntese líquida (A), condutância estomática (Gs) em resposta à densidade de fluxo de fótons fotossintéticos (DFFF) de Brachiaria mutica cultivada em dois Plintossolos sob duas condições de umidade $(n=4)$

A E. polstachya no solo 1 em ambas condições de umidade, apresentou menores Gs, no entanto, as A permaneceram elevadas. De maneira geral, a alta correlação entre Gs e A é observada em ambos os solos e condições de umidade.

O ambiente reduzido altera as propriedades físico-químicas dos solos, ocasionado aumentos de pH e diminuições no potencial de oxiredução, danificando o sistema radicular das plantas. No entanto, notou-se pela resposta de A e Gs que os processos fisiológicos de ambos os capins não foram afetados.

Em geral, a capacidade fotossintética e a condutância estomática de B. mutica e E. polystachya foram elevadas quando comparadas com os resultados obtidos em 
experimentos sob alagamento (Dias Filho, 2002; Dias Filho e Carvalho, 2000; Ishida, 1998), nos quais capins como a Brachiaria decumbens $\left(\mathrm{A}=20-30 \mu \mathrm{mol} \mathrm{m} \mathrm{s}^{-1}\right.$ e $\mathrm{Gs}=$ 0,06-0,2 $\left.\mu \mathrm{mol} \mathrm{m} \mathrm{m}^{-2}\right)$, Paspalum notatum e Setaria anceps $\left(\mathrm{A}= \pm 10-15 \mu \mathrm{mol} \mathrm{m} \mathrm{s}^{-2} \mathrm{e}\right.$ Gs $=0,1-0,2 \mu \mathrm{mol} \mathrm{m} \mathrm{m}^{-2}$ ), apresentaram valores inferiores às espécies avaliadas.

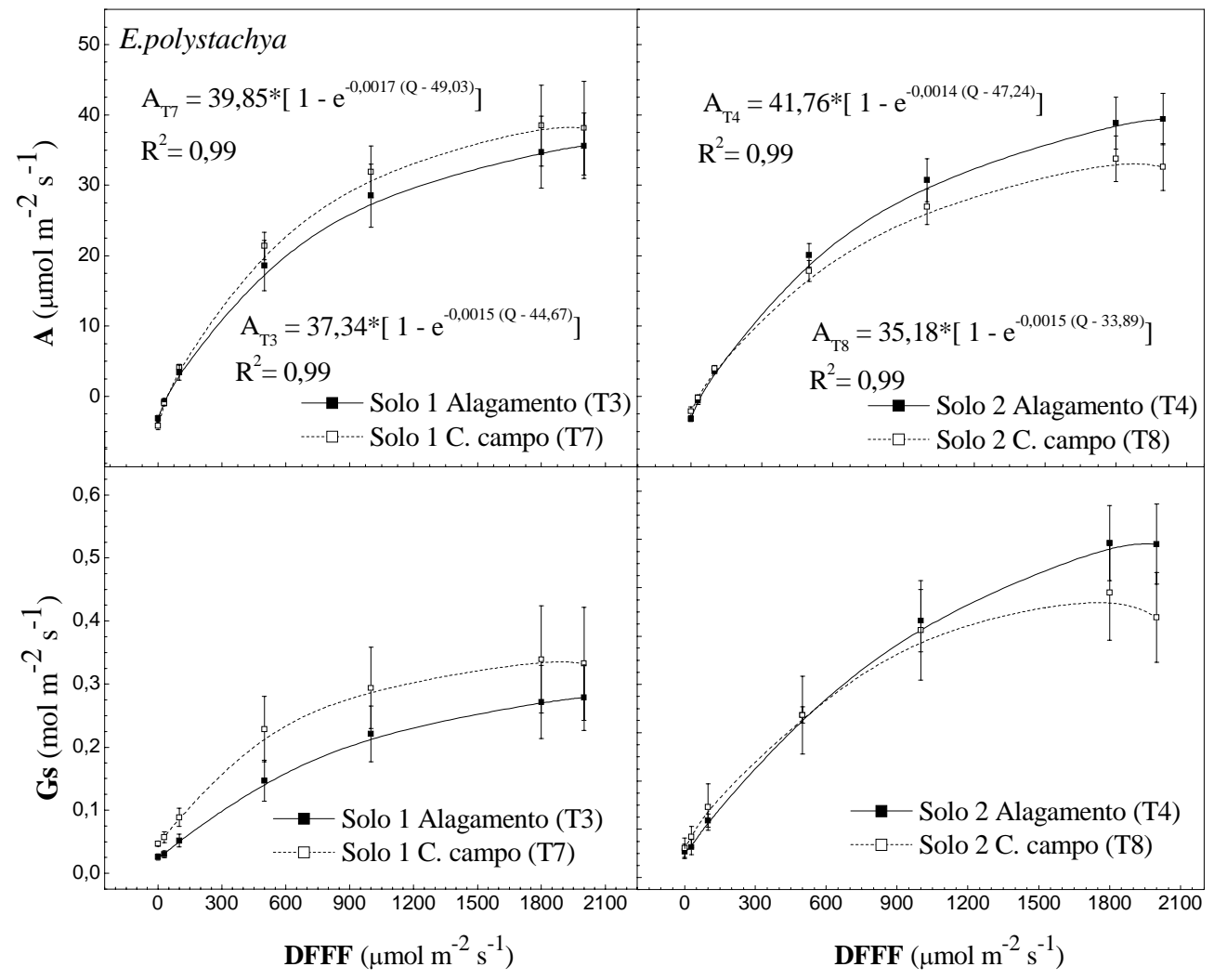

Figura 18 - Taxas de fotossíntese líquida (A), condutância estomática (Gs) em resposta à densidade de fluxo de fótons fotossintéticos (DFFF) de Echinochloa polystachya cultivada em dois Plintossolos sob duas condições de umidade $(\mathrm{n}=4)$ 


\subsubsection{Atividade da álcool desidrogenase (ADH)}

De maneira geral, verifica-se que o alagamento dos capins provocou um aumento na atividade enzimática nas raízes em ambas espécies estudadas, embora a atividade também tenha sido detectada nos capins sob capacidade de campo.

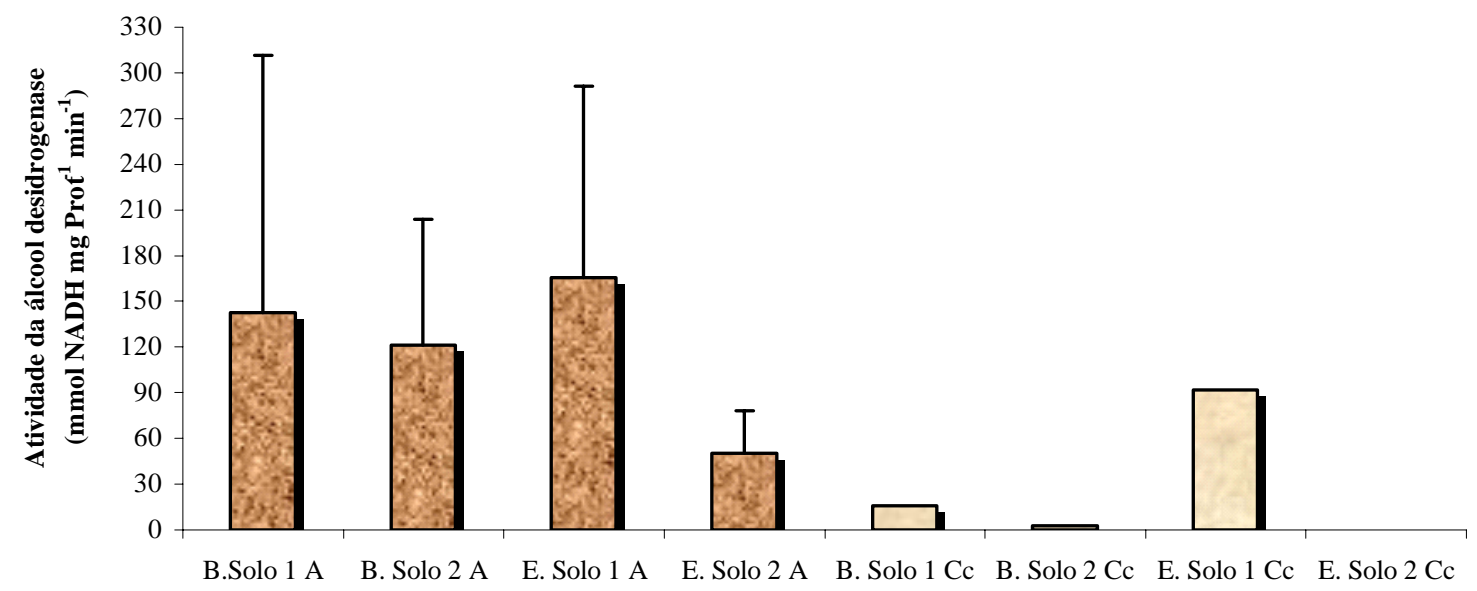

Figura 19 - Atividade da álcool desidrogenase (ADH) em raízes de duas gramíneas forrageiras tropicais cultivadas em dois Plintosolos (glei humicos) submetidas a diferentes condições de umidade $((\mathrm{B}=$ B. mutica; $\mathrm{E}=$ E. polystachya; $\mathrm{A}=$ alagamento; $\mathrm{Cc}=$ Capacidade de campo)

O alagamento estimulou a atividade da enzima apresentando maior atividade para $E$. polystachya no solo 1 seguida da $B$. mutica no mesmo solo e depois no solo 2. Os capins cultivados na capacidade de campo também apresentaram atividade enzimática para B.mutica e E. polystachya ambas cultivadas no solo 1.

A variação na atividade da $\mathrm{ADH}$ parece estar associada com o tipo de solo nos quais as espécies foram cultivadas, pois se nota que maiores aumentos na atividade estão relacionados com o solo 1. Provavelmente, as mudanças físico-químicas ocorridas nesse solo devido ao alagamento provocaram alterações no metabolismo das plantas, induzindo a atividade da enzima. 
Moraes et al. (2001) avaliando a atividade da ADH em B. mutica e E. polystachya verificaram que os valores de atividade foram maiores ou iguais aquelas obtidas quando as espécies foram submetidas à aeração normal.

De acordo com a literatura, sob condições de deficiência de oxigênio, ocorre um aumento do metabolismo anaeróbico em determinado grupo de plantas, promovendo aumentos na atividade da álcool e lactato desidrogenase. Segundo Drew (1990), incrementos na atividade dessas enzimas tem sido relacionados às adaptações metabólicas das espécies para conseguirem sobreviver a anoxia mantendo a produção de ATP e reciclagem do poder redutor.

Segundo Tribuzy (1998) inúmeros autores atribuem a maior atividade da enzima $\mathrm{ADH}$ e LDH relacionada com a preservação da carga energética de adenilato, fundamental para manutenção da atividade metabólica celular mínima permitindo a sobrevivência das plantas sob condições de deficiência de oxigênio. Observou-se no presente trabalho que possível quantidade de energia produzida, associada com as adaptações morfofisiológicas (aerênquima e raízes adventícias) puderam garantir o crescimento em situação semelhante ao das plantas sob capacidade de campo.

\subsubsection{Número de perfilhos totais}

O número de perfilhos diferiu significativamente $(\mathrm{P}<0,05)$, no primeiro corte, em função apenas dos capins e da condição de umidade (Tabelas 8 e 9).

Tabela 8. Número médio de perfilhos basais da Brachiaria mutica e Echinochloa polystachya, no primeiro corte

\begin{tabular}{cc}
\hline B. mutica & E. polystachya \\
\hline Médias seguidas de letras iguais não diferem entre si, a 5\% de probabilidade pelo teste de Tukey
\end{tabular}


Tabela 9. Número médio de perfilhos basais em função de diferentes condições de umidade, no primeiro corte

\begin{tabular}{cc}
\hline Alagamento & Capacidade de campo \\
\hline $29,56^{\mathrm{B}}$ & $50,12^{\mathrm{A}}$ \\
\hline Médias seguidas de letras iguais não diferem entre si, a $5 \%$ de probabilidade pelo teste de Tukey
\end{tabular}

Médias seguidas de letras iguais não diferem entre si, a 5\% de probabilidade pelo teste de Tukey

O número de perfilhos foi diferente entre capins, o que se atribuiu ao próprio hábito de crescimento de cada espécie, que apesar de serem estoloníferas, a B. mutica apresentou uma maior capacidade em produzir perfilhos do que a E. polystachya (Tabela 8). Porém, essas plantas apesar de tolerantes a condições alagadiças, também sofreram redução no perfilhamento, o que pode ser observado na Tabela 9.

Os efeitos do alagamento sobre essas espécies tolerantes não as deixaram livres dos danos provocados por tal ambiente, mostradas pela influência desse estresse na redução em 40\% do perfilhamento quando comparadas as diferentes condições de umidade (Tabela 9).

O segundo corte promoveu alteração no perfilhamento em ambas as espécies, apresentando comportamento diferente no número de perfilhos em função da interação significativa $(\mathrm{P}<0,05)$ entre capins e condições de umidade (Tabela 10).

Tabela 10. Número médio de perfilhos basais da Brachiaria mutica e Echinochloa polystachya em função de diferentes condições de umidade, no segundo corte

\begin{tabular}{lcc}
\hline Capim & Alagamento & Capacidade de campo \\
\hline B. mutica & $53,50^{\mathrm{aB}}$ & $90,00^{\mathrm{aA}}$ \\
E. polystachya & $23,12^{\mathrm{bB}}$ & $46,12^{\mathrm{bA}}$ \\
\hline
\end{tabular}

Médias seguidas de letras iguais, minúsculas na coluna e maiúsculas na linha, não diferem entre si, a 5\% de probabilidade pelo teste de Tukey

Em geral, tanto no primeiro como no segundo corte houve a redução do número de perfilhos nos capins pelo alagamento em relação à capacidade de campo. Observa-se que para os capins dentro de cada condição de umidade, a capacidade de campo proporcionou maior perfilhamento, pois não houve limitação para crescimento e desenvolvimento das espécies. Assim como, ao se comparar os capins dentro de cada condição de umidade, 
verifica-se que a $B$. mutica apresentou maior números de perfilhos em relação a $E$. polystachya, embora o incremento no número de perfilhos também possa ter sido influenciado pelo efeito dos cortes e pelo próprio hábito de crescimento da espécie.

\subsubsection{Produção de matéria seca da parte aérea e área foliar}

A produção total de matéria seca da parte aérea, em ambos os cortes realizados, variou significativamente $(\mathrm{P}<0,05)$ em função das condições de umidade, dos capins e do tipo de solo em que foram cultivadas (Tabelas 11 e 12).

Por ocasião do primeiro corte realizado, observou-se o efeito das condições de umidade sobre os capins, favorecendo maiores produções quando alagadas do que em capacidade de campo, principalmente para B. mutica em função de sua adaptação a esse tipo de condição. Nessa primeira fase do experimento, o efeito do alagamento foi benéfico, devido ao aumento do pH em ambiente de pouca concentração de oxigênio, o que favoreceu maior disponibilidade dos nutrientes contidos nos solo, aumentando a absorção desses nutrientes, e promovendo assim aumento no desenvolvimento das plantas.

Tabela 11. Produção total de matéria seca (g / caixa), da parte aérea da Brachiaria mutica e Echinochloa polystachya, em função de diferentes condições de umidade, no primeiro corte

\begin{tabular}{lll}
\hline Capim & Alagamento & Capacidade de campo \\
\hline B. mutica & $48,87^{\mathrm{aA}}$ & $29,53^{\mathrm{aB}}$ \\
\hline E. polystachya & $33,26^{\mathrm{bA}}$ & $27,87^{\mathrm{aA}}$ \\
\hline
\end{tabular}

Médias seguidas de letras iguais, minúsculas na coluna e maiúsculas na linha, não diferem entre si, a 5\% de probabilidade pelo teste de Tukey

Os resultados de produção total de matéria seca de parte aérea, a partir do segundo corte, mostram efeito significativo $(P<0,05)$ para capins em função do tipo de solo em que foram cultivados (Tabela 12). 
Tabela 12. Produção total de matéria seca (g / caixa), da parte aérea da Brachiaria mutica e Echinochloa polystachya, em função dos tipos de solo, no segundo corte

\begin{tabular}{lll}
\hline Capim & Solo 1 & Solo 2 \\
\hline B. mutica & $17,16^{\mathrm{bB}}$ & $21,32^{\mathrm{aA}}$ \\
E. polystachya & $21,38^{\mathrm{aA}}$ & $19,43^{\mathrm{aA}}$ \\
\hline
\end{tabular}

Médias seguidas de letras iguais, minúsculas na coluna e maiúsculas na linha, não diferem entre si, a 5\% de probabilidade pelo teste de Tukey

A produção total de matéria seca da parte aérea, no segundo corte, diferiu para $B$. mutica em relação aos solos 1 e 2, onde houve uma maior produção no solo 2. Enquanto que, comparando-se os capins cultivados no solo 1 , a produção de matéria seca de $E$. polystachya foi maior do que a $B$. mutica.

Segundo Guimarães (2000) avaliando a produção de matéria seca da parte aérea desses mesmos capins cultivados nos mesmos solos, observou que a $B$. mutica obteve maiores produções quando cultivada no solo 2.

O solo 2 mais uma vez demonstrou influenciar na resposta sobre a produção de matéria seca para $B$. mutica, o que pode estar relacionado com as propriedades físicas do mesmo, no entanto a E. polystachya não apresentou diferença de produção entre solos cultivados.

Os resultados obtidos confirmam com os observados por Haddade et al. (2002) que ao avaliar o crescimento de capins sob diferentes períodos de alagamento, verificou que a $B$. mutica foi a espécie mais adaptada às condições de inundação, mesmo no período mais prolongado.

As produções de matéria seca de lâminas foliares para o primeiro e segundo corte diferiram significativamente $(\mathrm{P}<0,05)$ em função das condições de umidade e da interação entre solos e condições de umidade (Tabela 13). 
Tabela 13. Produção de matéria seca de lâmina foliar (g / caixa) em função de diferentes condições de umidade, no primeiro e segundo corte

\begin{tabular}{cccc}
\hline Corte & Solo & Alagamento & Capacidade de campo \\
\hline $1^{\mathrm{o}}$ & Solos 1 e 2 & $23,47^{\mathrm{B}}$ & $33,43^{\mathrm{A}}$ \\
$2^{\mathrm{o}}$ & Solo 1 & $9,15^{\mathrm{aB}}$ & $13,91^{\mathrm{bA}}$ \\
& Solo 2 & $6,96^{\mathrm{aB}}$ & $18,05^{\mathrm{aA}}$ \\
\hline
\end{tabular}

Médias seguidas de letras iguais, minúsculas na coluna e maiúsculas na linha, não diferem entre si, a 5\% de probabilidade pelo teste de Tukey

O alagamento afetou a produção de matéria seca de lâmina foliar em ambos os cortes, o que pode ser atribuído a alterações nas propriedades físico-químicas dos solos pelo déficit de oxigênio promovendo redução do crescimento das plantas, em função dos danos causados ao metabolismo e processos fisiológicos das espécies.

Os resultados observados relativos à diminuição da produção de matéria seca de lâminas foliares em função do alagamento, também foram obtidos por Baruch (1994), onde os capins B. mutica e E. polystachya apresentaram redução na produção de folhas em função aumento no crescimento de hastes e estolões.

Outra mudança provocada nas lâminas foliares pelo alagamento foi a redução da área foliar da B. mutica, deixando-as mais estreitas. Essa diminuição de área foliar foi observada também no segundo corte, entretanto, somente em virtude das condições de umidade (Tabela 14).

Tabela 14. Área foliar $\left(\mathrm{cm}^{2}\right)$ da Brachiaria mutica e Echinochloa polystachya em função de diferentes condições de umidade, no primeiro e segundo corte

\begin{tabular}{cccc}
\hline Corte & Capim & Alagamento & Capacidade de campo \\
\hline $1^{\circ}$ & $\begin{array}{l}\text { B. } \text { mutica } \\
\text { E. polystachya }\end{array}$ & $2538,85^{\mathrm{aB}}$ & $5763,93^{\mathrm{aA}}$ \\
& $3152,15^{\mathrm{aA}}$ & $3902,36^{\mathrm{bA}}$ \\
$2^{\mathrm{o}}$ & $\mathrm{ns}$ & $2049,00^{\mathrm{B}}$ & $3166,1^{\mathrm{A}}$ \\
\hline $\begin{array}{l}\text { Médias seguidas de letras iguais, minúsculas na coluna e maiúsculas na linha, não diferem entre si, a 5\% de probabilidade } \\
\text { ns= não significativo }\end{array}$
\end{tabular}


A B. mutica demonstrou uma diminuição significativa $(\mathrm{P}<0,05)$ da área foliar em função do alagamento, enquanto a E. polystachya praticamente manteve sua área foliar, o que pode estar associado a maior tolerância a períodos prolongados de anoxia.

Outra possível causa da redução na área foliar pode estar associada ao aumento da concentração de ABA (ácido abscísico) que pode ser responsável pela mudança no crescimento das plantas (Alam, 1999).

Baruch (1994) obteve resultados para as mesmas espécies estudadas onde o alagamento influenciou em aproximadamente 70,3\% e 76,4\% na redução da área foliar em relação à capacidade de campo, para B. mutica e E. polystachya, respectivamente.

Huang et al. (1995) observaram que a redução da área foliar durante o alagamento em cultivares de trigo foi mais severa nos cultivares sensíveis do que nos tolerantes ao alagamento. Essa redução (83\%) esteve associada primariamente a deficiência nutricional em função dos danos causados ao sistema radicular.

Lizaso e Ritchie (1997) trabalhando com plantas de milho submetidas a inundação parcial também observou a redução na área foliar após 10 dias sob condição de estresse, atribuído ao mecanismo de ajuste osmótico, o qual mantinha a pressão de turgor requerida para continuar a expansão foliar, muito embora existam outros fatores que possam estar envolvidos.

A produção de matéria seca de haste apresentou diferenças significativas no primeiro corte $(\mathrm{P}<0,05)$, para a interação entre capim e condições de umidade, e no segundo corte, apenas para condições de umidade (Tabela 15). 
Tabela 15. Produção de matéria seca de haste (g / caixa) da Brachiaria mutica e Echinochloa polystachya, em função de diferentes condições de umidade, no primeiro e segundo corte

\begin{tabular}{cccc}
\hline Corte & \multicolumn{1}{c}{ Capim } & Alagamento & Capacidade de campo \\
\hline \multirow{2}{*}{$1^{-}$} & B. mutica & $32,00^{\mathrm{bB}}$ & $57,76^{\mathrm{aA}}$ \\
& E. polystachya & $48,42^{\mathrm{aA}}$ & $42,29^{\mathrm{bA}}$ \\
$2^{0}$ & $\mathrm{~ns}$ & $55,73^{\mathrm{A}}$ & $34,05^{\mathrm{B}}$ \\
\hline
\end{tabular}

Médias seguidas de letras iguais, minúsculas na coluna e maiúsculas na linha, não diferem entre si, a $5 \%$ de probabilidade. ns= não significativo

Vê-se na interação dos fatores uma menor produção de matéria seca de haste da B. mutica sob alagamento em relação a E. polystachya, o que pode ser atribuído ao comportamento da E. polystachya em elongar a haste. A elongação das hastes faz parte de uma série de alterações morfofisiológicas ocorridas na planta, como estratégia de sobrevivência, o que provavelmente contribuiu no acúmulo de massa seca nas hastes. Esse aumento, segundo diversos autores é típico em plantas tolerantes a ambientes alagadiços.

Resultados semelhantes foram obtidos por Piedade (1991) para espécies como E. polystachya oriundas de ambientes com inundações periódicas, onde a lâmina de água pode atingir até 8 m, têm como estratégia de sobrevivência a elongação de hastes a fim de manter o dossel sempre acima da lâmina de água.

Baruch (1994) observou que a B. mutica e E. polystachya mantiveram equilíbrio na alocação de biomassa nas diferentes partes da planta, com exceção do aumento na proporção de hastes e estolões sob alagamento, atribuído à eficiência na capacidade de difusão de oxigênio em plantas de ambientes alagados.

O mecanismo de elongação de hastes é considerado como modo de “escapar” do impacto causado pelo alagamento, assegurando a manutenção dos processos de crescimento pela emersão da folhagem das plantas na superfície da água, que podem estar associados a produção de fitohormônios, visto que o etileno possui influência na elongação da parte aérea de plantas aquáticas submersas (Joshi, 1999).

Segundo Naidoo e Naidoo (1992) a realocação de reservas dos órgãos localizados acima e abaixo da superfície da água durante o período de alagamento, são 
provavelmente uma estratégia metabólica efetiva na redução da quantidade de tecido radicular respirante relativo ao volume de raiz.

Ishida (1998) analisando a produção de biomassa em diferentes partes da planta de Paspalum repens observou que houve ganho de matéria seca direcionada para o crescimento das hastes na espécie, independente dos níveis de inundação estudados.

A produção de matéria seca de material morto no primeiro corte, diferiu significativamente $(\mathrm{P}<0,05)$ na interação entre capins e tipos de solo, enquanto no segundo corte, apenas para o tipo de solo, onde apesar da significância não houve diferença ao se fazer a comparação no teste de médias (Tabela 16).

Tabela 16. Produção de matéria seca de material morto (g / caixa) da Brachiaria mutica e Echinochloa polystachya, em função dos tipos de solo, no primeiro corte

\begin{tabular}{lll}
\hline Capim & Solo 1 & Solo 2 \\
\hline B. mutica & $1,85^{\mathrm{bA}}$ & $1,21^{\mathrm{aA}}$ \\
E. polystachya & $4,37^{\mathrm{aA}}$ & $2,02^{\mathrm{aB}}$
\end{tabular}

Médias seguidas de letras iguais, minúsculas na coluna e maiúsculas na linha, não diferem entre si, a 5\% de probabilidade pelo teste de Tukey

A E. polystachya apresentou maiores produções de material morto em relação a B. mutica quando cultivadas no mesmo tipo de solo (solo 1). Observa-se que para $E$. polystachya cultivada nesse mesmo solo, a resposta das produções revela aumento de produção de matéria seca dos componentes da planta (frações lâmina e haste), em virtude do crescimento e desenvolvimento da espécie, acarretando maior deposição de material morto devido à competição pela luz.

A produção de matéria seca de material morto, no segundo corte, não apresentou diferença no teste de comparação de médias, em função da condição de umidade. Todavia, observou-se aumento de material morto encontrado nas plantas submetidas ao alagamento, em relação a capacidade de campo. Esse acúmulo de material morto pode ter sido em decorrência do período prolongado do alagamento. 


\subsubsection{Relação folha:haste}

Segundo Nascimento Jr. e Rocha (2001) a relação folha:haste é considerada variável de grande importância para o manejo da planta forrageira. A alta relação folha:haste representa forragem de maior teor de proteína bruta, digestibilidade e consumo.

Observou-se durante um dia inteiro, após o corte da E. polystachya, a rápida elongação da haste em aproximadamente $2 \mathrm{~cm}$, e após dois dias o aparecimento dos primeiros tecidos foliares, para ambas as condições (Figura 20).

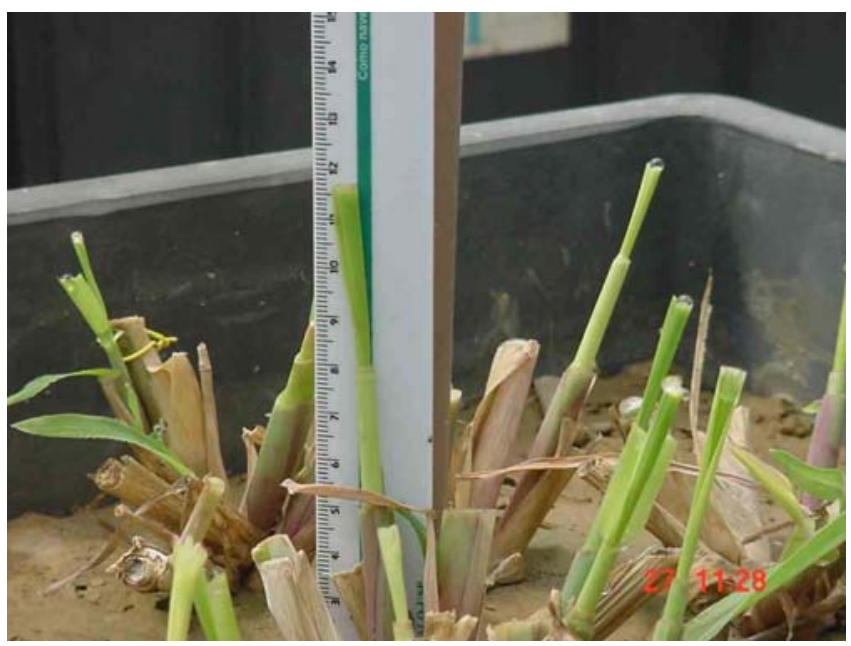

Figura 20 - Elongação de haste e lâmina foliar dois dias após o corte em E. polystachya

A relação folha:haste diferiu significativamente $(\mathrm{P}<0,05)$ somente no primeiro corte para interação capins e condições de umidade (Tabela 17). Observou-se que o alagamento influenciou na maior relação folha:haste da $B$. mutica e menor para $E$. polystachya, devido menor produção de matéria seca nas lâminas foliares e maior de hastes. 
Tabela 17. Relação folha:haste da Brachiaria mutica e Echinochloa polystachya, em função de diferentes condições de umidade, no primeiro corte

\begin{tabular}{lcc}
\hline Capim & Alagamento & Capacidade de campo \\
\hline B. mutica & $0,73^{\text {aA }}$ & $0,61^{\text {bA }}$ \\
E. polystachya & $0,53^{\text {bB }}$ & $0,85^{\text {aA }}$ \\
\hline
\end{tabular}

Médias seguidas de letras iguais, minúsculas na coluna e maiúsculas na linha, não diferem entre si, a 5\% de probabilidade pelo teste de Tukey. Dados transformados para $\log 10$.

A relação folha:haste em ambos os cortes não diferiu significativamente $(\mathrm{P}>0,05)$ em relação os fatores estudados, embora, tenha-se notado que a sucessão de cortes afetou a redução da relação para todos os tratamentos. De modo geral, as relações foram baixas, contribuindo para maior proporção de hastes do que lâminas, devido características próprias das espécies avaliadas (Figura 21).

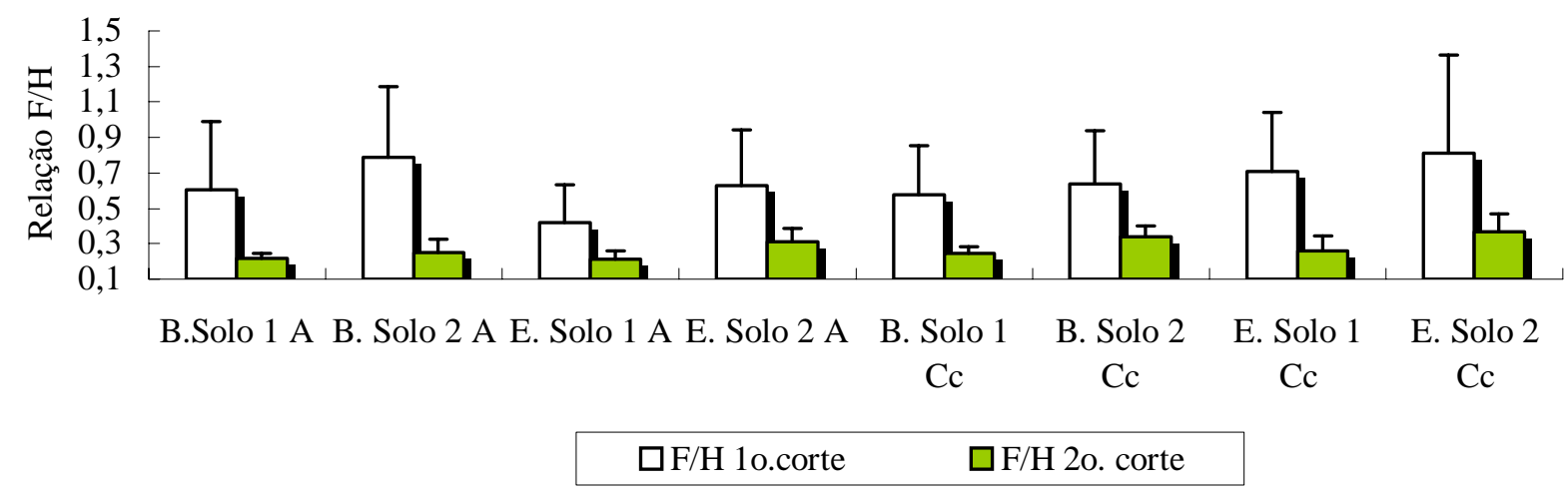

Figura 21 - Relação folha:haste em relação aos tratamentos analisados $(\mathrm{B}=$ B . mutica;

$$
E=\text { E. polystachya } ; \mathrm{A}=\text { alagamento } \mathrm{Cc}=\mathrm{C} \text {. campo })(\mathrm{n}=4)
$$




\subsubsection{Produção de matéria seca de raiz}

A produção de raiz apresentou uma interação significativa $(\mathrm{P}<0,05)$ entre os três fatores analisados: capins, solos e condições de umidade (Tabela 18).

Tabela 18. Produção de raiz (g / caixa) da Brachiaria mutica e Echinochloa polystachya em função dos tipos de solos submetidos a diferentes condições de umidade

\begin{tabular}{|c|c|c|c|c|}
\hline \multirow{2}{*}{ Capim } & \multicolumn{2}{|c|}{ Alagamento } & \multicolumn{2}{|c|}{ Capacidade de campo } \\
\hline & Solo 1 & Solo 2 & Solo 1 & Solo 2 \\
\hline B. mutica & $48,57^{\mathrm{bA}}$ & $53,27^{\mathrm{aA}}$ & $46,42^{\mathrm{bA}}$ & $40,60 \mathrm{bA}$ \\
\hline E. polystachya & $89,47^{\mathrm{aA}}$ & $56,52^{\mathrm{aB}}$ & $76,20^{\mathrm{aA}}$ & $74,72^{\mathrm{aA}}$ \\
\hline
\end{tabular}

Médias seguidas de letras iguais, minúsculas na coluna e maiúsculas na linha, não diferem entre si, a $5 \%$ de probabilidade pelo teste de Tukey

Os resultados obtidos para produção de raiz, em função de cada capim quando cultivado nos dois solos e sob diferentes condições de umidade, demonstraram que houve diferença significativa apenas para E. polystachya cultivada no solo 2, sob alagamento $(\mathrm{P}<0,05)$.

O aumento da produção de matéria seca radicular da E. polystachya em relação ao solo 1 e condições de umidade deve-se provavelmente a maior formação de raízes adventícias, influenciando na maior absorção de nutrientes para a planta, visto que a função desse sistema radicular está em substituir o sistema original prejudicado pela condição de estresse.

A substituição do sistema radicular original prejudicado por raízes adventícias, como estratégia de amenizar os danos causados pelo alagamento, é considerado por muitos autores como uma resposta benéfica para o metabolismo das plantas. Segundo Alam (1999) tais respostas têm sido observadas em plantas de arroz e outras espécies tolerantes que conseguem crescer e continuam absorvendo com eficiência os nutrientes disponíveis sob tal condição. Muitas dessas espécies iniciam um sistema adventício 
vigoroso que prolifera de maneira abundante sobre a superfície da água e em algumas porções aeradas de solos submersos.

Ao compararmos as espécies dentro de cada tipo de solo e condição de umidade, verifica-se que a $B$. mutica apresentou menores produções de matéria seca de raiz em relação a $E$. polystachya $(\mathrm{P}<0,05)$ independente dos fatores de estudo, principalmente quando cultivada no solo 1 sob alagamento.

A capacidade de E. polystachya em evitar danos sobre o metabolismo em condições de déficit de oxigênio por meio da formação de raízes adventícias, provavelmente contribuiu para melhorar a absorção dos nutrientes do solo sob ambiente reduzido. Essa alteração na morfologia e anatomia promoveu adição na produção de matéria seca radicular.

A produção de raízes dessa espécie pode ser claramente observada durante a retirada do solo contido dentro das unidades experimentais, nos quais todo o volume de solo contido nas caixas foi explorado pelo sistema radicular, ocorrendo em alguns casos, presença de raízes nas tubulações de entrada de água (Figura 21).

A formação de raízes adventícias também influenciou na produção de raízes das espécies. Atribuiu-se um "score" visual de 0 a 4 (nenhum, 25, 50, 75 e 100\%, respectivamente) onde a E. polystachya cultivada no solo 1 apresentou $75 \%$ da superfície do solo explorada por raízes adventícias e 100\% para a B. mutica no solo 2.

A aparecimento das raízes adventícias ocorreu a partir do quinto dia após o corte de uniformização, e a distribuição dessas raízes na superfície do solo foi uniforme em cada espécie, o que pode ser observado nas Figuras 22 e 23.

Jackson e Drew (1984), Armstrong et al., (1994), Dias Filho (2002), ressaltam que tolerância ao alagamento está fortemente relacionada à formação de raízes adventícias, acreditando que elas possam substituir funções realizadas pelas raízes afetadas, auxiliando na sobrevivência e recuperação da planta através do fornecimento de água, nutrientes e hormônio, bem como agindo como dreno dos fotoassimilados da parte aérea para o sistema radicular. 


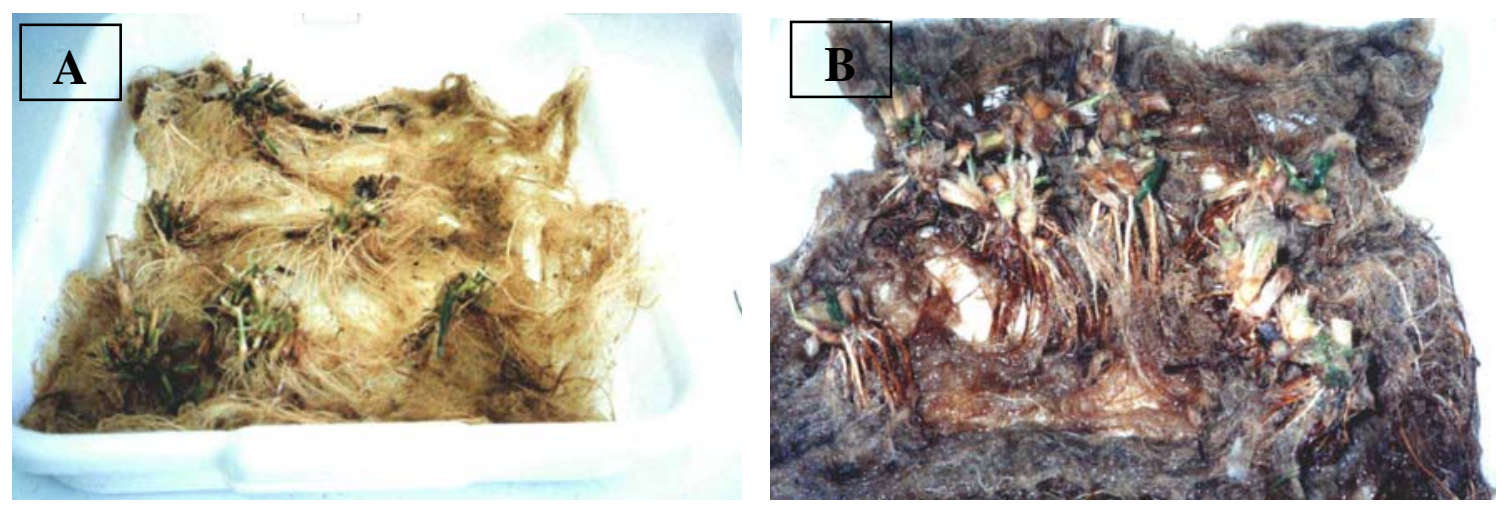

Figura 22. Raízes de B. mutica sob capacidade de campo (A), e E. polystachya sob alagamento (B)
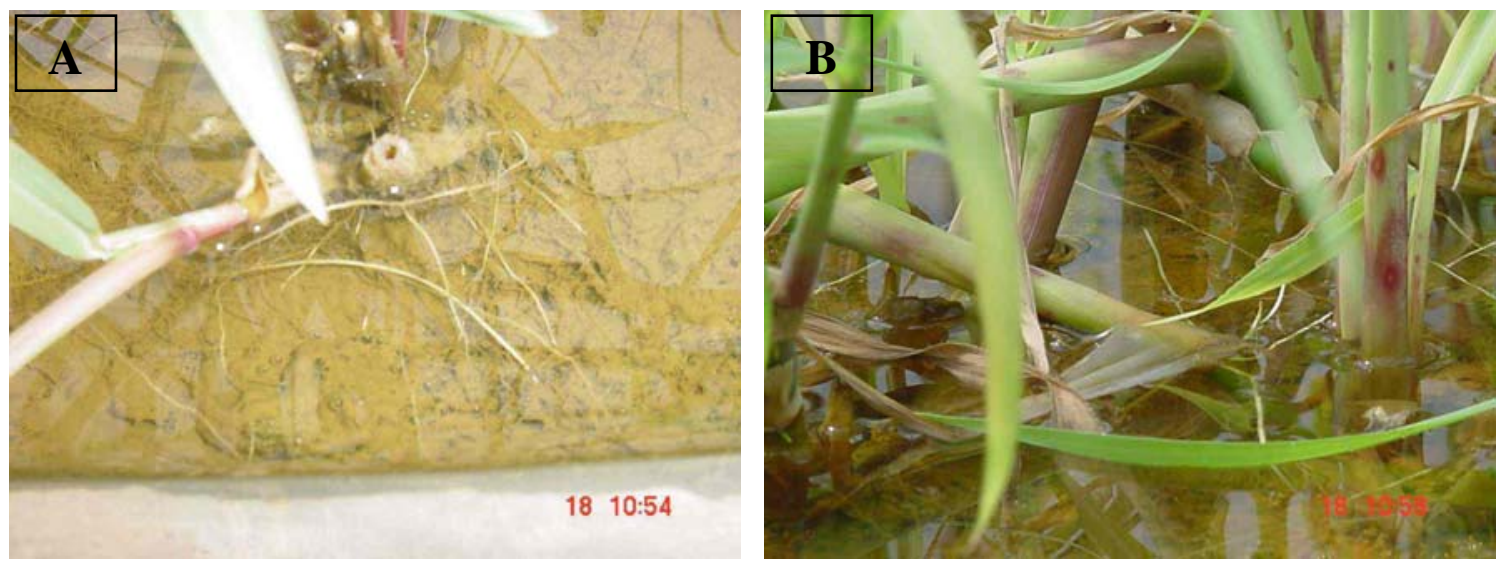

Figura 23. Distribuição de raízes adventícias em B. mutica (A) e E. polystachya (B) no solo 1, 18 dias após o corte de uniformização

\subsection{Composição química}

Os resultados obtidos para macro e micronutrientes apresentam diferenças significativas $(P<0,05)$ em função de interações entre capins e condições de umidade, capins e tipo de solo, e fatores isolados relativos ao primeiro e segundo corte. Tais resultados estão reunidos nas Tabelas 19 a 21. 
Tabela 19. Teores de macronutrientes $\left(\mathrm{g} \mathrm{kg}^{-1}\right.$ ) na matéria seca de lâminas foliares, da Brachiaria mutica e Echinochloa polystachya em função de condições de umidade e tipos de solo, no primeiro e segundo cortes

\begin{tabular}{|c|c|c|c|c|c|c|c|}
\hline \multirow[t]{2}{*}{ Nutriente } & \multirow[t]{2}{*}{ Corte } & \multirow[t]{2}{*}{ Capim } & \multicolumn{2}{|c|}{ Condição de umidade } & \multirow[t]{2}{*}{ Capim } & \multicolumn{2}{|c|}{ Tipo de solo } \\
\hline & & & Alagamento & $\begin{array}{l}\text { Capacidade } \\
\text { de campo }\end{array}$ & & Solo 1 & Solo 2 \\
\hline \multirow{4}{*}{$\mathrm{P}$} & $1^{o}$ & B. mutica & $1,83^{\mathrm{Ba}}$ & $1,83^{\mathrm{aA}}$ & B. mutica & $2,08^{\mathrm{bA}}$ & 1,59 aA \\
\hline & & E. polystachya & $2,69^{\mathrm{aA}}$ & $1,84^{\mathrm{aB}}$ & E. polystachya & $2,82^{\mathrm{aA}}$ & $1,65^{\mathrm{aB}}$ \\
\hline & $2^{\underline{0}}$ & B. mutica & $1,61^{\mathrm{bA}}$ & $1,66^{\mathrm{aA}}$ & B. mutica & $2,06^{\mathrm{bA}}$ & $1,21^{\mathrm{bB}}$ \\
\hline & & E. polystachya & $2,42^{\mathrm{aA}}$ & $1,80^{\mathrm{aB}}$ & E. polystachya & $2,79^{\mathrm{aA}}$ & $1,44^{\mathrm{aB}}$ \\
\hline \multirow{3}{*}{$\mathrm{K}$} & $1^{o}$ & B. mutica & $\mathrm{ns}^{(\mathbf{1})}$ & & B. mutica & $10,78^{\mathrm{aB}}$ & $16,39^{\mathrm{bA}}$ \\
\hline & & E. polystachya & & & E. polystachya & $12,78^{\mathrm{aB}}$ & $23,49^{\mathrm{aA}}$ \\
\hline & $2^{\underline{0}}$ & ns & $12,25^{\text {B (2) }}$ & $17,87^{\mathrm{A}}$ & $n s$ & $10,89^{\text {B (2) }}$ & $19,24^{\mathrm{A}}$ \\
\hline \multirow[t]{2}{*}{$\mathrm{Ca}$} & $2^{0}$ & B. mutica & $4,34^{\mathrm{aA}}$ & $5,02^{\mathrm{bA}}$ & B. mutica & ns & \\
\hline & & E. polystachya & $4,07^{\mathrm{aB}}$ & $5,89^{\mathrm{aA}}$ & E. polystachya & & \\
\hline \multirow{4}{*}{ Mg } & $1^{\mathrm{o}}$ & B. mutica & $3,44^{\mathrm{aB}}$ & $5,31^{\mathrm{aA}}$ & B. mutica & ns & \\
\hline & & E. polystachya & $2,93^{\mathrm{aB}}$ & $6,20^{\mathrm{aA}}$ & E. polystachya & & \\
\hline & $2^{\underline{0}}$ & ns & $4,17^{\text {В (2) }}$ & $5,19^{A}$ & B. mutica & ns & \\
\hline & & & & & E. polystachya & & \\
\hline \multirow{4}{*}{ S } & $1^{\mathrm{o}}$ & B. mutica & $2,35^{\mathrm{bB}}$ & $3,65^{\mathrm{bA}}$ & B. mutica & ns & \\
\hline & & E. polystachya & $3,00^{\mathrm{aB}}$ & $6,00^{\mathrm{aA}}$ & E. polystachya & & \\
\hline & $2^{0}$ & B. mutica & $2,45^{\mathrm{aB}}$ & $4,49^{\mathrm{bA}}$ & B. mutica & ns & \\
\hline & & E. polystachya & $2,25^{\mathrm{aB}}$ & $5,68^{\mathrm{aA}}$ & E. polystachya & & \\
\hline
\end{tabular}

Médias seguidas de letras iguais, minúsculas na coluna e maiúsculas na linha, não diferem entre si, a 5\% de probabilidade pelo teste de Tukey e t- Student

(1) ns = não significativo; (2) significativo apenas para um fator de estudo, onde $n=16$

\subsubsection{Fósforo}

Os teores de fósforo encontrados na matéria seca de lâminas foliares, em ambos os cortes, apresentaram diferenças significativas $(\mathrm{P}<0,05)$ para as interações entre capins e condições de umidade, e capins e tipos de solo (Tabela 19).

Observa-se em ambos os cortes que a E. polystachya sob alagamento, apresentou desempenho semelhante verificando-se maiores teores de fósforo em relação à $B$. mutica 
dentro de uma mesma condição. No entanto, nota-se que esses teores sofreram redução na concentração do tecido de um corte para outro, o que deve estar associado com a fixação desse elemento no solo, afetando sua disponibilidade e consequente absorção.

A disponibilidade de fósforo foi verificada pelas análises de fertilidade dos solos realizadas no decorrer do experimento mostrando que os teores foram influenciados pelas condições de umidade, o que confirma a resposta das espécies pelo nutriente com valores médios no primeiro corte de 15 e $13 \mathrm{mg} \mathrm{dm}^{-3}$, e no segundo de 8 e $8 \mathrm{mg} \mathrm{dm}^{-3}$ para os solos alagados e na capacidade de campo, respectivamente.

O alagamento provavelmente favoreceu a disponibilidade desse nutriente para $E$. polystachya em virtude do aumento da solubilidade em $\mathrm{pH}$ elevados, típicos de ambientes reduzidos. O fósforo em solos ácidos é encontrado sob a forma de fosfatos de Fe e de $\mathrm{Al}$, liberando íons $\mathrm{HPO}_{4}^{-2}$ a medida que o $\mathrm{pH}$ atinge valores maiores que 5,3. Contudo a absorção do elemento dependerá da condição do sistema radicular das espécies sob tal ambiente (Pezeshki, 2001).

Segundo Alam (1999), plantas tolerantes ao alagamento frequentemente crescem melhor e apresentam maior absorção de fósforo quando comparadas àquelas de ambientes aerados. Tais respostas foram encontradas em espécies de cereais, algumas angiospermas e em arroz, nos quais o ambiente reduzido proporcionou aumento nas produções de matéria seca associado com o aumento na disponibilidade desse nutriente no solo.

Ao avaliarmos os resultados obtidos em função da interação capins e tipos de solo, verifica-se que no primeiro corte, a E. polystachya em relação ao tipo de solo apresenta maiores teores no solo 1 , o mesmo se dá ao compararmos a $B$. mutica, na qual a diferença significativa também é encontrada no solo 1.

O segundo corte apresentou também diferenças significativas, para cada espécie em função do tipo de solo, nos quais em ambos os capins os maiores teores de fósforo estiveram associados ao solo 1.

Segundo Luz et al. (2001), baseado nos teores de fósforo encontrados nas plantas em bom estado nutricional, a faixa adequada dos teores de fósforo em $B$. decumbens $e$ 
brizantha variam de 0,8 a 3,0 $\mathrm{g} \mathrm{kg}^{-1}$, portanto, os valores obtidos neste trabalho, estão de acordo com os teores citados pelos autores.

\subsubsection{Potássio}

Os teores de potássio apresentaram diferenças significativas $(\mathrm{P}<0,05)$ no primeiro corte, para a interação entre capins e tipo de solo, enquanto no segundo corte, observou-se significância apenas para fatores isolados, para condições de umidade e tipos de solo.

No primeiro corte, os teores de potássio obtidos para capins em função do tipo de solo revelam que houve maior concentração desse nutriente para ambas as espécies quando cultivadas no solo 2, entretanto observa-se que para os teores encontrados entre capins, dentro de cada solo, a E. polystachya apresenta maiores teores desse nutriente, o que deve estar relacionada com a sua eficiência na absorção desse elemento presente no solo.

O segundo corte apresenta diferenças significativas para efeitos isolados, nos quais se verifica menor concentração nos capins em função do alagamento e quando cultivados no solo 1 .

Alam (1999), relatou sobre os efeitos inibitórios da absorção de potássio em algumas culturas sob alagamento, devido a alteração na disponibilidade da matéria orgânica e da capacidade de troca catiônica (CTC) dos solos, o que pode comprometer o crescimento das plantas.

De modo geral, a concentração do potássio no tecido vegetal está relacionada com a disponibilidade desse elemento no solo, visto a mobilidade que possui o que acaba refletindo diretamente sobre a matéria seca da parte aérea da planta. Nesse sentido, observou-se que alguns dos teores encontrados no primeiro e segundo cortes estão abaixo do limite mínimo recomendado (12 $\left.\mathrm{g} \mathrm{kg}^{-1}\right)$, por Luz et al. (2001), onde alguns tratamentos apresentaram sintomas de deficiência desse nutriente, principalmente naqueles em que a análise de solo revelou baixa concentração ( $\left.<1,5 \mathrm{mg} \mathrm{dm}^{-3}\right)$, confirmando a associação entre teores na planta e solo. 


\subsubsection{Cálcio}

Os teores de cálcio apresentaram diferenças significativas $(\mathrm{P}<0,05)$ para o fator capins, e interação entre capins e condições de umidade, no primeiro e segundo cortes, respectivamente.

No primeiro corte, a E. polystachya $\left(5,08 \mathrm{~g} \mathrm{~kg}^{-1}\right)$ apresentou maior teor de cálcio na matéria seca lâminas foliares, em relação a $B$. mutica $\left(4,02 \mathrm{~g} \mathrm{~kg}^{-1}\right)$, enquanto no segundo corte, verifica-se que os capins apresentaram redução nos teores sob alagamento. Apesar dos teores refletirem bom estado nutricional (2 - $6 \mathrm{~g} \mathrm{~kg}^{-1}$ ) das espécies, essa diminuição provavelmente está relacionada com danos causados sobre o sistema radicular afetando os mecanismos de absorção desse nutriente no solo. Embora a produção de matéria seca de raiz tenha sido estimulada, a eficiência de absorção por esses tecidos possa estar comprometida.

A redução dos teores de cálcio pode estar relacionada à diminuição do crescimento dos capins, pois de acordo com Drew (1992), a absorção metabólica desse nutriente por algumas culturas, pode ser retardada em virtude da dependência de suprimento adequado de oxigênio no ambiente, onde sob tal condição de estresse, há falta de agentes ligantes próximos ao sistema radicular que mediem mecanismos de absorção ativa e as concentrações de cálcio e magnésio, o que pode justificar a redução dos teores observados nas plantas.

Kozlowski (1984), descreveu que plantas que toleram períodos prolongados de alagamento podem absorver mais macronutrientes do que espécies sensíveis, porém, a concentração mineral pode sofrer reduções ao invés de altas taxas de absorção, no qual entre os nutrientes, a absorção de cálcio é a menos prejudicada.

Alam (1999) relatou que o alagamento apresenta efeitos inibitórios menores sobre o acúmulo de cálcio na planta em relação a nitrogênio, fósforo e potássio, visto que em plantas de arroz houve aumento da concentração nos tecidos de cálcio, fósforo e ferro. 


\subsubsection{Magnésio}

O magnésio assim como o cálcio apresentou diferença significativa $(\mathrm{P}<0,05)$ no primeiro corte, na interação entre capins e condição de umidade, e no segundo somente para condições de umidade.

Os teores de magnésio na matéria seca da parte aérea foram reduzidos em ambos os capins, quando submetidos ao alagamento. Observa-se diminuição no teor para $E$. polystachya em relação à $B$. mutica, embora não tenha havido diferença significativa $(\mathrm{P}>0,05)$ quando comparamos as espécies dentro da mesma condição.

As condições de umidade também afetaram o teor de magnésio na matéria seca da parte aérea das espécies, no segundo corte. O alagamento reduziu em 20\% o teor em relação à capacidade de campo, entretanto, o estresse nada afetou o estado nutricional das plantas, pois os teores observados encontram-se de acordo com os valores considerados adequados nutricionalmente, variando entre 1,5 a 6,0 $\mathrm{g} \mathrm{kg}^{-1}$, segundo Luz et al. (2001).

O bom estado nutricional dos capins pode ser atribuído às altas concentrações existente nos solos 1 e 2 sob alagamento, que variou em média de 44 a 87 mmolc dm ${ }^{-3}$, respectivamente.

Moraes e Dynia (1992) avaliando a influência da calagem sobre solos gley submetidos a inundação, verificaram aumento nos teores de magnésio em virtude de solubilização do corretivo, enquanto que nos solos sem calagem houve aumento em função do seu deslocamento do complexo de troca pelo ferro e manganês.

\subsubsection{Enxofre}

Os teores de enxofre apresentaram diferenças significativas $(\mathrm{P}<0,05)$ em ambos os cortes, para interação entre capins e condições de umidade.

O alagamento afetou os teores de enxofre dos capins em ambos os cortes. No primeiro corte, houve diferença para os capins submetidos em cada uma das condições de umidade, como também, entre eles dentro de uma mesma condição. O segundo corte, apresentou diferenças significativas semelhantes em relação ao primeiro, com exceção da comparação realizada entre capins sob alagamento $(\mathrm{P}>0,05)$. 
Em geral, a $B$. mutica apresentou menores teores de enxofre em relação à $E$. polystachya, com exceção do segundo corte onde houve apenas diferença significativa na capacidade de campo.

$\mathrm{O}$ alagamento reduz a quantidade de sulfato $\left(\mathrm{SO}_{4}{ }^{2-}\right)$ disponível para absorção pelas espécies, devido a instabilidade do sulfato em condições de ambiente anaeróbico, onde $\mathrm{SO}_{4}{ }^{2-}$ é reduzido a sulfeto ( $\mathrm{S}^{-}, \mathrm{HS}$ e $\mathrm{H}_{2} \mathrm{~S}$ ), forma predominante em solos alagados, segundo Alvares (1990).

Ambientes reduzidos ou alagados podem inibir a oxidação do enxofre e inutilizar a absorção pela cultura de arroz devido a mudanças na faixa de $\mathrm{pH}$ comum em condições redutoras, causando diminuição drástica na adsorção de sulfato e, sua dependência em função do pH é elevada, a disponibilidade tende a ser praticamente negligenciada visto que o ambiente reduzido promove aumentos de $\mathrm{pH}$ entre 6,7 a 7,2, sendo assim, a disponibilidade de enxofre encontrada nas plantas de arroz são inferiores em relação a condições aeradas (Alam, 1999).

Apesar dos teores reduzidos para capins sob alagamento, os mesmos são considerados adequados, variando de 0,8 a 3,0 $\mathrm{g} \mathrm{kg}^{-1}$, conforme descritos por Luz et al. (2001). Contudo, observa-se um acúmulo desse nutriente na matéria seca dos capins na capacidade de campo, em decorrência do aumento da concentração do nutriente nos solos ocasionada pela correção da acidez.

Os teores de micronutrientes na matéria seca de lâminas foliares estão apresentados em função das diferenças significativas $(\mathrm{P}<0,05)$ obtidas para cada nutriente reunidos nas Tabelas 20 e 21. 
Tabela 20. Teores de micronutrientes $\left(\mathrm{mg} \mathrm{kg}^{-1}\right)$ na matéria seca lâminas foliares, da Brachiaria mutica e Echinochloa polystachya em função de condições de umidade e tipos de solo, no primeiro e segundo cortes

\begin{tabular}{|c|c|c|c|c|c|c|c|}
\hline \multirow[t]{2}{*}{ Nutriente } & \multirow[t]{2}{*}{ Corte } & \multirow[t]{2}{*}{ Capim } & \multicolumn{2}{|c|}{ Condição de umidade } & \multirow[t]{2}{*}{ Capim } & \multicolumn{2}{|c|}{ Tipo de solo } \\
\hline & & & Alagamento & $\begin{array}{c}\text { Capacidade } \\
\text { de campo }\end{array}$ & & Solo 1 & Solo 2 \\
\hline B & $2^{\underline{0}}$ & $\begin{array}{l}\text { B. mutica } \\
\text { E. polystachya }\end{array}$ & ns ${ }^{(1)}$ & & ns (1) & $5,54^{\mathrm{B}}$ & $7,92^{\mathrm{A}}$ \\
\hline & $1^{\mathrm{o}}$ & Ns & $5,89^{\mathrm{B}}$ & $8,63^{A}$ & ns & $6,05^{\mathrm{B}}$ & $8,47^{\mathrm{A}}$ \\
\hline u & $2^{\underline{0}}$ & Ns & $5,28^{\text {B (2) }}$ & $8,39^{\mathrm{A}}$ & ns & $5,43^{\mathrm{B}}$ & $8,24^{\mathrm{A}}$ \\
\hline $\mathrm{Fe}$ & $1^{\underline{0}}$ & Ns & $148,81^{\mathrm{A}}$ & $132,44^{\text {B }}$ & $\begin{array}{l}\text { B. mutica } \\
\text { E. polystachya }\end{array}$ & $\begin{array}{l}162,00^{\mathrm{aA}} \\
116,80^{\mathrm{bA}}\end{array}$ & $\begin{array}{l}142,11^{\text {aA }} \\
129,88^{\text {aA }}\end{array}$ \\
\hline & $1^{\mathrm{o}}$ & $\begin{array}{l}\text { B. mutica } \\
\text { E. polystachya }\end{array}$ & $\begin{array}{c}68,68^{\mathrm{aA}} \\
108,70^{\mathrm{aB}}\end{array}$ & $\begin{array}{l}95,60^{\mathrm{bA}} \\
250,97^{\mathrm{aA}}\end{array}$ & $\begin{array}{l}\text { B. mutica } \\
\text { E. polystachya }\end{array}$ & ns & \\
\hline & $2^{0}$ & $\begin{array}{l}\text { B. mutica } \\
\text { E. polystachya }\end{array}$ & $\begin{array}{c}64,43^{\mathrm{aA}} \\
104,46^{\mathrm{aB}}\end{array}$ & $\begin{array}{l}83,25^{\mathrm{bA}} \\
226,30^{\text {aA }}\end{array}$ & $\begin{array}{l}\text { B. mutica } \\
\text { E. polystachya }\end{array}$ & ns & \\
\hline $\mathrm{Zn}$ & $1^{\underline{o}}$ & $\begin{array}{l}\text { B. mutica } \\
\text { E. polystachya }\end{array}$ & $\begin{array}{l}18,81^{\mathrm{aB}} \\
18,76^{\mathrm{aB}}\end{array}$ & $\begin{array}{l}23,84^{\mathrm{bA}} \\
29,58^{\mathrm{aA}}\end{array}$ & $\begin{array}{l}\text { B. mutica } \\
\text { E. polystachya }\end{array}$ & $\begin{array}{l}22,53^{\mathrm{aA}} \\
24,45^{\mathrm{aA}}\end{array}$ & $\begin{array}{l}20,11^{\mathrm{bB}} \\
23,89^{\mathrm{aA}}\end{array}$ \\
\hline
\end{tabular}

Médias seguidas de letras iguais, minúsculas na coluna e maiúsculas na linha, não diferem entre si, a 5\% de probabilidade pelo teste de Tukey e t-Student

(1) ns = não significativo; (2) significativo apenas para um fator de estudo, onde $n=16$

Tabela 21. Teores de boro e ferro ( $\mathrm{mg} \mathrm{kg}^{-1}$ ) na matéria seca da parte aérea da Brachiaria mutica e Echinochloa polystachya, no segundo corte

\begin{tabular}{ccc}
\hline Nutriente & B. mutica & E. polystachya \\
\hline $\mathrm{B}$ & $8,96^{\mathrm{A}}$ & $4,50^{\mathrm{B}}$ \\
$\mathrm{Fe}$ & $152,97^{\mathrm{A}}$ & $127,98^{\mathrm{B}}$ \\
\hline Médias seguidas de letras iguais não diferem entre si, a 5\% de probabilidade pelo teste de Tukey
\end{tabular}

Médias seguidas de letras iguais não diferem entre si, a 5\% de probabilidade pelo teste de Tukey 


\subsubsection{Boro}

Os teores de boro apresentaram diferenças significativas $(\mathrm{P}<0,05)$ apenas no segundo corte, de maneira isolada para os fatores tipo de solo e capim (Tabelas 22 e 23).

Os teores de boro encontrados estão abaixo da faixa considerada adequada, pois deveriam variar de 10 a $30 \mathrm{mg} \mathrm{kg}^{-1}$ conforme Luz et. al (2001).

A deficiência desse nutriente nos solos pode ter sido influenciada pelo efeito da correção da acidez do solo, reduzindo os teores existentes nas plantas, visto que antes da aplicação do corretivo os teores contidos nos solos 1 e 2 eram de 0,6 e 0,8 mg kg-1, respectivamente.

As formas solúveis de boro são facilmente disponíveis para as plantas, que podem absorvê-la como ácido bórico não dissociado, bem como outras formas existentes no meio. O boro é imóvel na planta, acumulando-se nas folhas mais velhas, nas quais o seu teor é maior nas pontas e margens (Dechen et. al, 1991).

Os teores de boro obtidos em função dos capins, revelam que a B. mutica apresenta maior teor que a E. polystachya, apesar desses valores estarem abaixo da faixa adequada o que poderia comprometer o estado nutricional das espécies (Tabela 23).

A redução dos teores encontrados na planta foi atribuída a deficiência desse nutriente nos solos, verificado nas análises de solo realizadas antes de cada um dos cortes. Decréscimos nos teores de boro em cada corte foram encontrados nas mesmas espécies por Guimarães (2000).

\subsubsection{Cobre}

Os teores de cobre apresentaram diferenças significativas em ambos os cortes para efeitos isolados como condições de umidade e tipo de solo $(\mathrm{P}<0,05)$.

Em ambos os cortes, os teores de cobre obtidos para condição de umidade e tipos de solo, apresentaram uma redução na concentração desse nutriente nas plantas sob alagamento e solo 1, no entanto, os valores estão de acordo com a variação de 4 a 20 mg $\mathrm{kg}^{-1}$, indicados por Luz et. al (2001). 
Os teores de cobre, observados nos cortes 1 e 2 apresentaram comportamento semelhante em cada condição de umidade, havendo a mesma diferença significativa $(\mathrm{P}<0,05)$ na concentração desse nutriente entre alagamento e capacidade de campo.

O ambiente reduzido influenciou na absorção de cobre pelas plantas, o que pode ser atribuído a complexação do elemento por compostos orgânicos provenientes da decomposição da matéria orgânica em solos inundados, segundo Moraes e Dynia (1992).

Os capins quando cultivados no solo 1, apresentaram menores teores de cobre em virtude da menor concentração do nutriente existente no solo em consequência de características físico-química próprias desse solo (Tabelas 5 e 6).

Os menores teores de cobre obtidos em função das concentrações existentes do elemento no solo 1, podem estar relacionadas não somente a forte ligação existente entre complexos orgânicos e o elemento, como também a diminuição da disponibilidade em função do pH elevado.

As análises de solos realizadas antes e após a correção, bem como após o primeiro e segundo cortes revelaram que o solo 1 apresentou teores menores em relação ao solo 2, apesar de considerados de acordo com os teores recomendados $(0,3$ a $0,8 \mathrm{mg}$ $\mathrm{dm}^{-3}$ ) por Luz et. al (2001).

\subsubsection{Ferro}

Os resultados obtidos apresentaram diferenças significativas $(P<0,05)$ no primeiro corte, para a interação capins e tipo de solo, e no segundo corte somente para capins (Tabelas 20 e 21).

Os teores de ferro, encontrados na matéria seca de lâminas foliares em ambos os cortes são considerados adequados (50 a $250 \mathrm{mg} \mathrm{dm}^{-3}$ ), de acordo com as concentrações indicadas por Luz et. al (2001).

A E. polystachya apresentou menores teores de ferro em relação à B. mutica, diferindo significativamente $(\mathrm{P}<0,05)$, somente quando cultivadas no solo1. O tipo de solo em que os capins foram cultivados possuem teores distintos de ferro, tendo o solo 1 os teores mais elevados. O excesso de ferro nos solos não afetou as espécies, embora, 
tanto a absorção quanto o transporte desse elemento na planta sejam fortemente afetados por fatores da planta e ambientais, tais como pH, concentrações de cálcio e fósforo.

O alagamento promoveu a elevação dos teores de ferro no solo alterando a concentração desse elemento nas plantas, visto que o ambiente anaeróbico aumenta a solubilidade do ferro no solo, reduzindo de $\mathrm{Fe}^{3+}$ a $\mathrm{Fe}^{2+}$, aumentando a disponibilidade de $\mathrm{Fe}^{2+}$, forma absorvida pelas plantas.

O aumento da concentração de ferro na solução do solo é causado pela redução do $\mathrm{Fe}^{3+}$ a $\mathrm{Fe}^{2+}$, na ausência de oxigênio por bactérias anaeróbicas que usam os componentes oxidados do solo como receptores de elétrons na sua respiração (Ponnamperuma, 1972).

O segundo corte apresentou teor de ferro da B. mutica maior que para $E$. polystachya. Essa mesma resposta, também pode ser observada no primeiro corte quando se comparou o capim em função dos tipos de solo.

\subsubsection{Manganês}

Os teores de manganês apresentaram diferenças significativas $(\mathrm{P}<0,05)$ em ambos os cortes, para a interação capins e condição de umidade.

A E. polystachya apresentou maiores teores de manganês, em ambos os cortes em relação à $B$. mutica. Nota-se que há o efeito do alagamento sobre os capins, bem como redução dos teores de um corte para outro.

Os teores de manganês, encontrados na matéria seca da parte aérea dos capins variaram dentro faixa recomendada por Luz et. al (2001), de 40 a $250 \mathrm{mg} \mathrm{dm}^{-3}$.

Os teores de manganês sofreram reduções para cada capim, nos dois cortes, em função do alagamento, havendo diferenças significativas $(\mathrm{P}<0,05)$ para capim em cada uma das condições estudadas e entre espécies na capacidade de campo, onde a $E$. polystachya obteve um teor de manganês $38 \%$ maior que a $B$. mutica.

A redução dos teores de manganês nas espécies sob alagamento pode ter sido atribuída a fatores que influenciam a absorção desse elemento pelas plantas em ambientes anaeróbios. 
De acordo com uma sequência termodinâmica o manganês começa a ser reduzido após o consumo de oxigênio e da redução do nitrato, por ter um potencial de oxi-redução mais elevado que o ferro o que promove o seu rápido aumento na concentração do solo em ambientes alagados (Moraes e Dynia,1992).

\subsubsection{Zinco}

Os teores de zinco apresentaram diferenças significativas $(\mathrm{P}<0,05)$ somente no primeiro corte, para interações capins e condições de umidade, capins e tipo de solo.

O alagamento reduziu os teores de zinco em relação à capacidade de campo, quando se comparou cada capim em função das condições de umidade. Observa-se que a diferença foi significativa $(\mathrm{P}<0,05)$ apenas entre capins quando cultivados na capacidade de campo.

Os teores de zinco encontrados em função do tipo de solo demonstram que a $B$. mutica apresentou uma diferença significativa entre o solo 1 e 2, enquanto que ao se comparar capins em cada tipo de solo, observa-se apenas diferença em função do solo 2.

Segundo Alam (1999), o aumento do pH em solos ácidos próximo da neutralidade, em condições de alagamento exercem forte influência na redução da disponibilidade de zinco e cobre na cultura de arroz alagado.

De acordo com Luz et. al (2001) os teores recomendados de zinco com base na matéria seca variam de 20 a $50 \mathrm{mg} \mathrm{kg}^{-1}$, verificado em alguns dos teores apresentados. Baseado na recomendação indicada pelos autores, alguns desses valores obtidos estão muito abaixo do sugerido, em decorrência da possível oclusão do zinco por compostos de ferro, como também pelo aumento de $\mathrm{pH}$.

\subsection{Composição químico - bromatológica}

Foram analisados os teores de matéria mineral, proteína bruta, fibra em detergente neutro, fibra em detergente ácido e lignina, nos dois cortes realizados nas (Tabelas 22 a 26). 


\subsubsection{Proteína bruta}

Os teores de proteína bruta diferiram significativamente em ambos os cortes $(\mathrm{P}<0,05)$. O primeiro corte apresentou efeito significativo para a interação capins e tipo de solo, enquanto no segundo apenas em função do tipo de solo (Tabelas 22 e 23).

Tabela 22. Teores de proteína bruta (\%) da matéria seca de lâminas foliares, da Brachiaria mutica e Echinochloa polystachya em função dos tipos de solo, no primeiro corte

\begin{tabular}{|c|c|c|}
\hline Capim & Solo 1 & Solo 2 \\
\hline B. mutica & $15,13^{\mathrm{aA}}$ & $16,21^{\mathrm{aA}}$ \\
\hline E. polystachya & $11,48^{\mathrm{bB}}$ & $16,78^{\mathrm{aA}}$ \\
\hline
\end{tabular}

Tabela 23. Teores de proteína bruta (\%) da matéria seca de lâminas foliares, em função dos tipos de solo, no segundo corte

\begin{tabular}{cc}
\hline Solo 1 & Solo 2 \\
\hline $12,42^{\mathrm{B}}$ & $15,17^{\mathrm{A}}$ \\
\hline Médias seguidas de letras iguais não diferem entre si, a 5\% de probabilidade pelo teste de Tukey
\end{tabular}

Os teores de proteína bruta obtidos em cada espécie em função do tipo de solo apresentaram significância $(\mathrm{P}<0,05)$ somente para E. polystachya, com maior teor protéico quando cultivada no solo 2, enquanto que a se comparar capins em um mesmo solo, verifica-se que a $B$. mutica obteve significativamente teores maiores.

Os teores de proteína obtidos no segundo corte revelam certa semelhança com os resultados obtidos no corte anterior, com a diferença de que a média obtida foi baseada em 16 repetições em relação as 8 do primeiro corte, no entanto, os resultados confirmam que os valores encontrados em ambos os cortes respondem em função das propriedades físico-químicas de cada solo.

Segundo Reis et. al (1993) relataram que a fertilidade do solo e a prática de adubação só reflete na composição química da planta, principalmente nos teores de 
proteína bruta, fósforo e potássio, conseqüentemente na digestibilidade e consumo da forragem.

Camarão et al. (1991), avaliaram durante dois anos, pastagens nativas de terra inundável do médio Amazonas, analisando teores de proteína bruta em 160 amostras de capins, entre as quais a E. polystachya apresentou 8,2\%. A composição química desse capim originário de terras inundáveis foi superior aos das gramíneas de terra firme, que situavam na faixa de 6 a $9 \%$.

\subsubsection{FDN, FDA e Lignina}

Os teores de FDN apresentaram diferenças significativas $(\mathrm{P}<0,05)$ para a interação capins e tipos de solo em ambos os cortes (Tabela 24).

Tabela 24. Teores de fibra em detergente neutro (FDN) (\%) da matéria seca de lâminas foliares, da Brachiaria mutica e Echinochloa polystachya em função dos tipos de solo, no primeiro e segundo cortes

\begin{tabular}{|c|c|c|}
\hline Capim & Solo 1 & Solo 2 \\
\hline & \multicolumn{2}{|c|}{$1^{0}$ corte } \\
\hline B. mutica & $29,8 \overline{5^{\mathrm{aA}}}$ & $22,55^{\mathrm{bA}}$ \\
\hline \multirow[t]{2}{*}{ E polystachya } & $30,21^{\mathrm{aA}}$ & $32,12^{\mathrm{aA}}$ \\
\hline & \multicolumn{2}{|c|}{$2^{\underline{0}}$ corte } \\
\hline B. mutica & $63,0 \overline{2^{a A}}$ & $62,27^{\mathrm{aA}}$ \\
\hline E. polystachya & $61,94^{\mathrm{aA}}$ & $58,39^{\mathrm{bB}}$ \\
\hline
\end{tabular}

Médias seguidas de letras iguais, minúsculas na coluna e maiúsculas na linha, não diferem entre si, a 5\% de probabilidade pelo teste t-Student Dados originais transformados $(\mathrm{FDN})^{2}$

No primeiro corte, ao comparar capins em função dos solos, observa-se que não houve diferença significativa entre eles, no entanto, quando se compara entre capins em um mesmo solo, verifica-se teores maiores de FDN para E. polystachya no solo 2. O segundo corte apresentou aumento, de maneira geral, nos teores de FDN, entretanto, a E. polystachya respondeu diferentemente ao solo 2, demonstrando valores menores nos teores em relação ao solo 1 . 
Os aumentos nos teores de FDN de um corte para outro, foram atribuídos provavelmente em função da idade de corte realizado aos 28 dias no primeiro corte, e 42 dias para o segundo, o que acarretou em aumento nos teores de FDN.

Segundo Camarão e Marques (1995) o efeito da idade de corte e de partes da planta provocou decréscimos nos teores de proteína bruta, extrato etéreo e matéria mineral nas gramíneas de terra firme e aumentos nos de fibra bruta e FDN (67,8\%) para E. polystachya.

Os teores de FDA apresentaram diferenças significativas $(\mathrm{P}<0,05)$ no primeiro corte para interação capins e condição de umidade, e no segundo apenas para capins (Tabela 25).

Tabela 25. Teores de fibra em detergente ácido (FDA) (\%) da matéria seca de lâminas foliares, em função de diferentes condições de umidade, capins e tipos de solo

\begin{tabular}{|c|c|c|c|c|}
\hline \multirow[t]{2}{*}{ Corte } & \multirow[t]{2}{*}{ Capim } & & \multicolumn{2}{|c|}{ Condição de umidade } \\
\hline & & & Alagamento & Capacidade de campo \\
\hline \multirow[t]{2}{*}{$1^{\mathrm{o}}$} & B. mutica & & $28,87^{\mathrm{bA}}$ & $29,53^{\mathrm{aA}}$ \\
\hline & E polystachya & & $32,85^{\mathrm{aA}}$ & $29,48^{\mathrm{aB}}$ \\
\hline \multirow[t]{2}{*}{$2^{0}$} & B. mutica & $30,01^{\mathrm{B}}$ & & \\
\hline & E polystachya & $31,68^{\mathrm{A}}$ & & \\
\hline
\end{tabular}

Médias seguidas de letras iguais, minúsculas na coluna e maiúsculas na linha, não diferem entre si, a 5\% de probabilidade pelo teste t-Student

Os teores de FDA em E. polystachya em função das condições de umidade apresentaram diferenças significativas $(\mathrm{P}<0,05)$ nos quais, o alagamento promoveu aumento da concentração em relação à capacidade de campo, bem como diferença significativa entre as espécies sob condições alagadas.

A mesma diferença nos teores de FDA em função dos capins foi obtida no segundo corte, para E. polystachya que apresentou maior teor em relação à B. mutica.

Em geral, tanto no primeiro como no segundo corte, observa-se maiores teores de FDA na E. polystachya, que pode estar relacionado ao genótipo diferente da espécie, sendo influenciado pelo ambiente causando alterações na composição química.

A E. polystachya apresentou menores teores de FDN e maiores de FDA quando comparada à $B$. mutica, esses teores podem estar associados com a concentração dos 
componentes da parede celular afetados pelo solo e alagamento, promovendo alterações na composição química. De acordo com Reis e Rodrigues (1993), fatores como espécie forrageira e condições ambientais exercem influência sobre a qualidade e composição química da forragem.

Os teores de lignina apresentaram diferenças significativas $(\mathrm{P}<0,05)$ para capim em ambos os cortes, e condição de umidade somente no segundo corte (Tabelas 26).

Tabela 26. Teores de lignina (\%) da matéria seca de lâminas foliares, da Brachiaria mutica e Echinochloa polystachya e para condições de umidade, no primeiro e segundo cortes

\begin{tabular}{|c|c|c|c|c|}
\hline \multirow{2}{*}{$\begin{array}{c}\text { Corte } \\
1^{-}\end{array}$} & \multicolumn{2}{|c|}{ Capim } & \multicolumn{2}{|c|}{ Condição de umidade } \\
\hline & B. mutica & E. polystachya & & \\
\hline & $3,03^{\mathrm{A}}$ & $2,59^{\mathrm{B}}$ & & \\
\hline $2^{\circ}$ & B. mutica & E. polystachya & Alagamento & Capacidade de campo \\
\hline & $2,61^{\mathrm{A}}$ & $2,21^{\mathrm{B}}$ & $2,25^{\mathrm{B}}$ & $2,57^{\mathrm{A}}$ \\
\hline
\end{tabular}

Médias seguidas de letras iguais, minúsculas na coluna e maiúscula na linha, não diferem entre si, a 5\% de probabilidade pelo teste de Tukey

A B. mutica em ambos os cortes, apresentou maiores teores de lignina em relação à E. polystachya. Nota-se que em ambas as espécies houve um decréscimo nos teores de um corte para outro, possivelmente atribuído a uma redução de tecido foliar produzido pelas espécies, confirmada pelas diminuições na produção de matéria seca de lâmina e área foliar.

Os teores de lignina dos capins de maneira geral sofreram também redução em decorrência do excesso de umidade. O alagamento reduziu a concentração de lignina independentemente da espécie e tipo de solo, que pode estar associada com características morfofisiológicas de espécies tipicamente tolerantes a ambientes alagadiços.

Outro aspecto que poderia influenciar na menor concentração de lignina seria a quantidade de água interna presente na estrutura foliar, dividindo com a lignina a mesma função em dar sustentação a estrutura foliar, influenciando assim na diluição desses teores.

As informações na literatura a respeito dos efeitos causados pelo déficit ou excesso de umidade sobre a composição químico-bromatológica de plantas forrageiras são muito 
escassas. Segundo Buxton e Fales (1994), ambas condições induzem o estresse em forragens, no qual o alagamento pode reduzir drasticamente a produção, entretanto pouco se conhece sobre os impactos causados na qualidade da forragem.

\subsection{Características físiso-químicas dos solos sob alagamento}

A modificação causada em função do ambiente alagado nos solos estudados, influenciou o crescimento das plantas em vários aspectos, em virtude das alterações físico-químicas que ocorreram no meio.

Huang (2000) relata que existem vários fatores que influenciam nas injúrias causadas pelo alagamento tais como: condições fisiológicas e estágio de crescimento da planta, temperatura, salinidade e disponibilidade de nutrientes.

\subsubsection{Temperatura do solo}

Mudanças de temperatura na época de alagamento possuem grande influência nas respostas das plantas no grau de injúria causada. O dano causado pelo alagamento aumenta à medida que eleva a temperatura. Nas regiões de clima temperado, a tolerância de plantas sob alagamento é maior durante o inverno e primavera, do que sob as altas temperaturas do verão. A temperatura do solo possui impactos ainda maiores sobre a tolerância ao alagamento do que a do ar (Huang, 2000).

A temperatura do solo foi monitorada durante todo o experimento. Essa medida foi dividida no tempo, o que consistiu em avaliar a sua variação antes e após cada corte.

Antes do primeiro corte, verificou-se uma diferença significativa $(\mathrm{P}<0,05)$ entre o tipo de solo e o primeiro dia, no qual o solo 2 apresentou maior temperatura $\left(34,85{ }^{\circ} \mathrm{C}\right)$ em relação ao solo $1\left(32,61{ }^{\circ} \mathrm{C}\right)$. O aumento de temperatura do solo 2, provavelmente esteve associado a atividade microbiana, devido a apresentar maior teor de matéria orgânica. 
Segundo Beard (1973) ${ }^{1}$ citado por Huang (2000), plantas de Festuca rubra morreram em apenas um dia sob alagamento à alta temperatura $\left(30^{\circ} \mathrm{C}\right)$, enquanto Agrostis palustris sobreviveu sob mesma condição durante 60 dias a $10^{\circ} \mathrm{C}$. As injúrias causadas pelo alagamento e baixa temperatura reduziram o teor de clorofila das folhas, a taxa fotossintética e a viabilidade radicular, enquanto que o aumento da temperatura provocou danos generalizados tanto na parte aérea como no sistema radicular, além do aumento na taxa respiratória das folhas como modo de manter a respiração sob temperatura elevada.

A Figura 24 ilustra as variações ocorridas no solo no decorrer do experimento, antes do segundo corte. Diferenças significativas $(\mathrm{P}<0,05)$ foram obtidas na interação entre capins e dias de avaliação, no entanto, apenas as médias e o erro padrão estão expressos no gráfico.

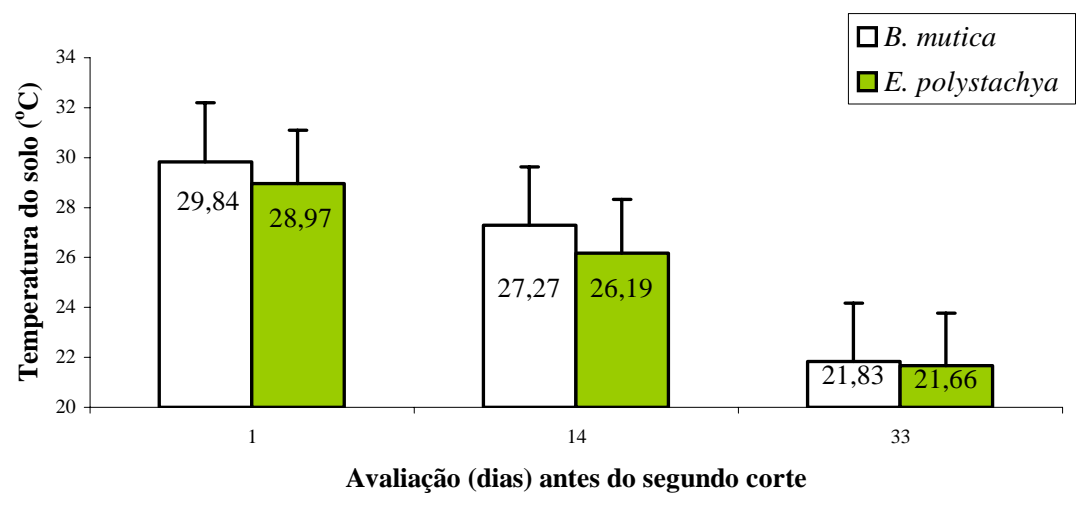

Figura 24 - Variação da temperatura do solo, no segundo corte, em função dos dias

As espécies apresentaram um mesmo comportamento, em função da variação da temperatura do solo, ao verificarmos as médias e os erros padrão apresentados.

Segundo Brady (1989) a temperatura do solo para um crescimento ótimo varia de acordo com o tipo de planta, assim como uma variação na temperatura para as diferentes

\footnotetext{
${ }^{1}$ BEARD, J.B. Turfgrass science and culture. In: CLIFFS, E. (Ed.) New Jersey: Prentice - Hall, 1973. p. 297-301.
} 
fases dos processos vegetais. A exemplo do milho, em que a produção de matéria seca atinge seu máximo quando a temperatura do solo atinge valores entre 26,7 a $29,4{ }^{\circ} \mathrm{C}$.

A tolerância ao alagamento para algumas espécies pode assegurar sua sobrevivência. Plantas de Lotus corniculatus consideradas tolerantes a ambientes alagadiços sobreviveram relativamente bem em diferentes zonas de temperaturas (25, 19 e $13^{\circ} \mathrm{C}$ ). A elevada tolerância dessa espécie ao alagamento à temperaturas baixas refletiu no aprimoramento da sua capacidade em se adaptar a condições de deficiência de oxigênio, diminuindo taxas de crescimento ou tornando o metabolismo do sistema radicular mais lento (Heinrichs, 1972).

\subsection{2 $\mathrm{pH}$ e Eh dos solos alagados}

A fim de compreender de que forma essas alterações aconteciam, foram realizadas medidas $\mathrm{pH}$ e Eh. Para isso foram realizadas medidas antes do primeiro corte, nos dias $1^{\circ}, 7,14$ e 21, e antes do segundo, nos dias $1^{0}$, 7, 14, 18, 22, 32 e 35.

Em ambientes alagados as plantas respondem em função das alterações fisicoquímicas do solo, que podem levar a uma série de sintomas de estresse. Inúmeras informações sobre respostas de plantas a ambientes alagados são descritas na literatura, no entanto, pouco se sabe sobre da relação entre oxiredução do solo e os processos fisiológicos das espécies.

Pezeshki (2001) cita a importância do ponto de vista ecofisiológico, em entender o efeito do pH e Eh (potencial de oxiredução) sobre o estado de vários compostos do solo e suas implicações sobre o funcionamento das espécies de terras inundáveis.

$\mathrm{O}$ pH apresentou variações no tempo que foram significativas $(\mathrm{P}<0,05)$ em função dos dias, muito embora não se possa inferir com mais precisão, em qual dos dias avaliados houve maior variação (Figura 25). 


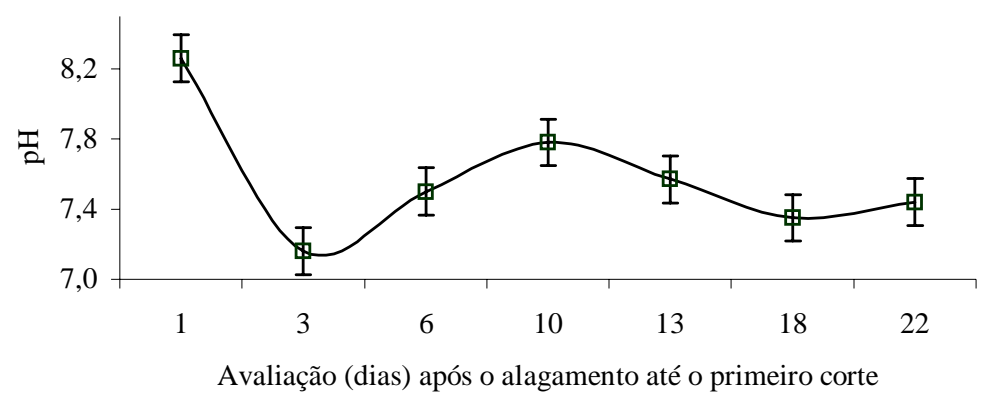

Figura 25 - Variação do pH da solução dos solos, antes do primeiro corte

Observa-se variação antes do primeiro até o terceiro dia de avaliação em condições alagadas, com aumento seguido de redução no $\mathrm{pH}$. Esse aumento de $\mathrm{pH}$ no início das avaliações foi provavelmente devido a atividade microbiana que ocorria nos solos sobre a decomposição da matéria orgânica antes do alagamento. No momento em que os solos sofreram o alagamento, houve rápido consumo de oxigênio, levando a redução mais rápida do meio (Figura 25).

Após o $16^{\circ}$ dia de avaliação, o pH começou apresentar menor oscilação, tendendo a estabilização entre valores 7, 0 a 7,5, o que ocorreu no decorrer do experimento, pelas medidas obtidas, apresentadas na Figura 26.

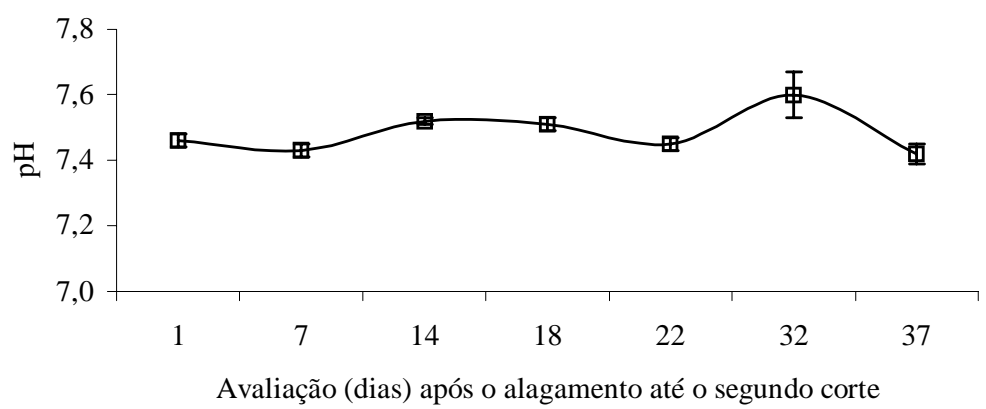

Figura 26 - Variação do pH da solução dos solos, antes do segundo corte 
A pouca variação do $\mathrm{pH}$ após o primeiro corte revelou que o ambiente de redução estava estabilizado, com isso houve a diminuição dos microorganismos aeróbicos e a proliferação de microorganismos próprios de ambientes reduzidos (Figura 26).

Mello et. al (1992), verificaram que nas alterações de pH em solos inundados, o aumento inicial de $\mathrm{pH}$ é atribuído provavelmente a ação microbiana no consumo de oxigênio.

O aumento do pH e a redução do Eh causado pelo alagamento em ambos os solos afetou a absorção dos minerais pelos capins. Ponnamperuma (1972), relatou que durante períodos prolongados de alagamento, o pH diminui enquanto o Eh continua a reduzir-se, favorecendo a liberação de vários nutrientes e aumentando a disponibilidade no meio. Esse efeito proporciona aumentos de concentração tanto no solo quanto nos tecidos vegetais, a exemplo do zinco, ferro e manganês, os quais apresentam quantidades superiores a dos ambientes aerados.

As reações de óxido redução são caracterizadas pela transferência de elétrons das espécies químicas oxidadas para as espécies químicas reduzidas, essas reações são mediadas por microorganismos que oxidam a matéria orgânica e alguns dos seus componentes são reduzidos.

O Eh variou significativamente $(\mathrm{P}<0,05)$ antes do primeiro corte, em função de tipos de solo e os dias avaliados. Os resultados de Eh para o solo 1 apresentaram resposta gráfica semelhante, conforme ilustra a Figura 27.

Observa-se que os valores de Eh em função dos solos 1 e 2, apresentam curvas de resposta com a mesma tendência, no decorrer do tempo.

O solo 1 apresentou ao longo do tempo reduções de Eh, que ao contrário do solo 2, atingiram valores muito baixos de até - 138, $96 \mathrm{mV}$. Os valores negativos de Eh representam um ambiente reduzido estabelecido e que podem estar associados com os altos teores de ferro encontrados nesse solo.

Segundo Ponnamperuma (1972), vários fatores influenciam no decréscimo de Eh após a inundação, sendo os principais o Eh inicial do solo, o teor de matéria orgânica, temperatura do solo e a quantidade de receptores de elétrons. 


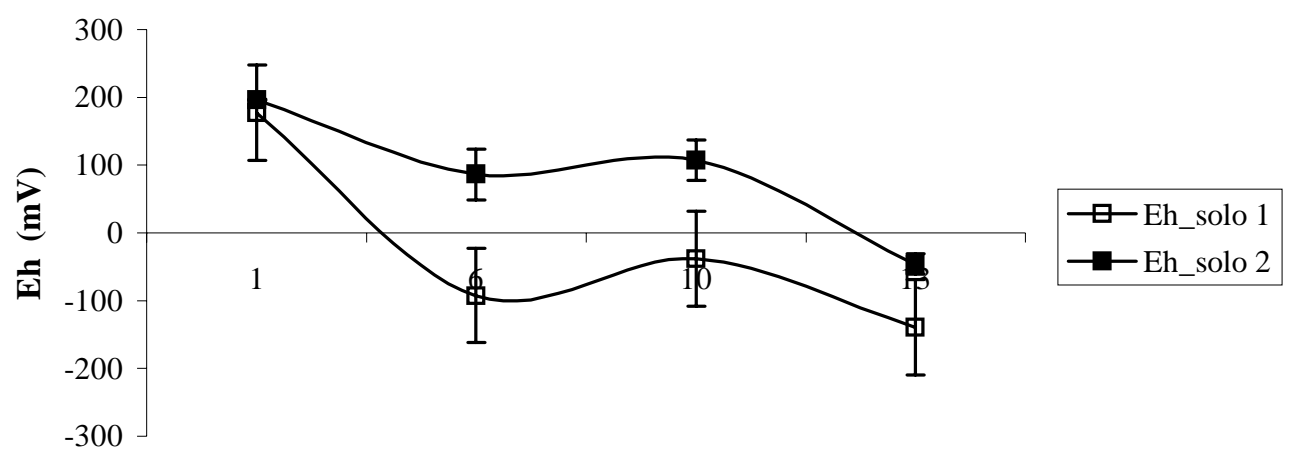

Avaliação (dias) após o alagamento até o primeiro corte

Figura 27 - Variação do Eh (mV) da solução do solo, em função dos dias antes do primeiro corte

O solo 2 (177,64 mV) apresentou maior Eh permanecendo até o penúltimo dia de avaliação, o motivo parece ser uma resistência desse solo em se oxidar e reduzir (Figura 27). Segundo Mello et al. (1992), essa resistência pode estar associada ao efeito da calagem que parece conferir aos solos, menores variações de pH e Eh.

Quantificar o Eh pode auxiliar na dinâmica das reações indicando qual possível elemento está passando por reduções e se há presença de oxigênio no meio, a exemplo do solo 2 onde o Eh até antes do primeiro corte apresentava-se em - $46 \mathrm{mV}$. Segundo a literatura, solos completamente reduzidos podem atingir $\mathrm{Eh}<-300 \mathrm{mV}$, o que reflete no metabolismo da espécies.

Pezeshki (2001), relatou a influência do Eh nas relações hídricas e trocas gasosas de plantas, provocando lentidão na absorção de água em relação a solos sob boa aeração, e decréscimos nas taxas fotossintéticas para algumas plantas, como o caso de Spartina repens, espécie de ambientes costeiros, que apresentou redução da atividade fotossintética decorrente da intensidade de redução do meio de crescimento com Eh abaixo de $-200 \mathrm{mV}$. Todavia, no presente trabalho ambas as espécies não apresentaram reduções nas taxas fotossintéticas e condutância estomática talvez o Eh (-200,52 mV) na época em que foram realizadas as medidas de fotossíntese ( $14^{\circ}$ dia após segundo corte) não tenha suficientemente contribuído para afetar os processos fisiológicos (Figura 28). 
Outro aspecto que pode ter mantido as altas taxas fotossintéticas pode estar relacionado com as mudanças morfofisiológicas ocorridas durante o alagamento como mecanismos de adaptação em condições de ambiente reduzidos.

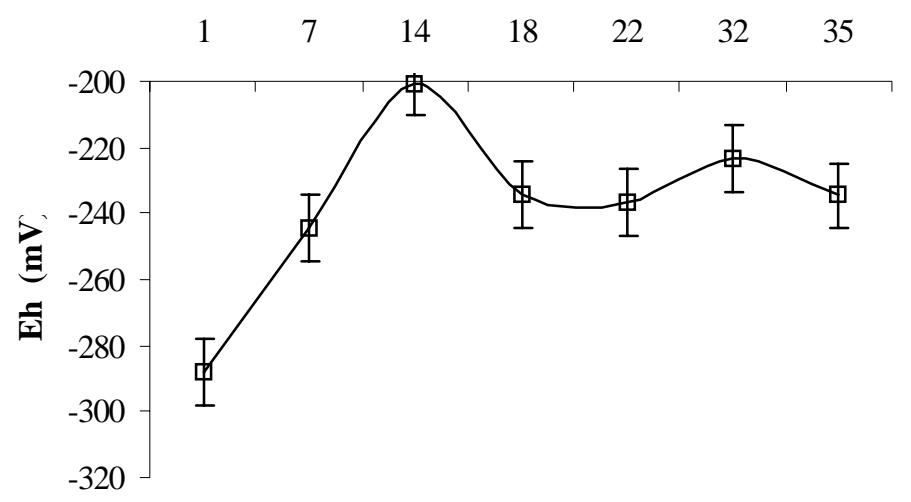

Figura 28 - Variação do Eh $(\mathrm{mV})$ da solução do solo, em função dos dias, após primeiro corte

No segundo corte, o potencial de oxi-redução de ambos os solos continuou a diminuir até alcançar os valores mais negativos, passando depois por um aumento a partir do $1^{\circ}$ dia de alagamento.

Segundo León e Arregocés (1981) quando os solos ácidos com alto potencial de oxi-redução, teor relativamente alto de matéria orgânica e de ferro, são inundados, o Eh se reduz drasticamente. Todavia, esse efeito não é tão acentuado em solos que possuem pH próximo a neutralidade e com teores médios de matéria orgânica.

A condição redutora dos solos é um dos fatores principais, em muitos ecossistemas sujeitos a inundações, que influencia a sobrevivência de espécies, seu crescimento, e produtividade. Ao quantificar o Eh dos solos pode-se entender melhor como plantas de tais ambientes, apesar de possuírem ampla faixa de mecanismos de tolerância ou escape, conseguem responder a essa condição (Pezeshki, 2001). 


\section{CONCLUSÕES}

Com base nos resultados obtidos no presente trabalho, pode-se concluir que:

As gramíneas forrageiras respondem diferentemente em função do alagamento e dos tipos de solos em relação as variáveis estudadas, onde a E. polystachya apresenta melhor capacidade de adaptação em relação a B. mutica, devido a características próprias de cada espécie.

A fotossíntese líquida e condutância estomática dos capins B. mutica e E. polystachya não são afetadas sob alagamento, o que se pode atribuir a ativação dos mecanismos de adaptações morfológicos, metabólicos e anatômicos das espécies.

A formação de raízes adventícias, o aumento na produção de matéria seca de hastes e raiz são estimulados pelo alagamento, contudo, houveram reduções na área foliar, nas produções de matéria seca de lâmina foliar e total, relação folha:haste, no número de perfilhos, indicando desequilíbrio na alocação da biomassa entre parte aérea e o sistema radicular, como mecanismo estratégico de sobrevivência ao meio de pouca oxigenação.

Os capins apresentam alterações na sua composição química com o alagamento, reduzindo os teores dos nutrientes para ambas as espécies, com exceção do fósforo e ferro, sem no entanto comprometer o estado nutricional das espécies.

O alagamento e tipo de solo alteram a composição químico-bromatológica das espécies forrageiras promovendo aumentos nos teores de fibra e redução nas concentrações de lignina.

As mudanças ocorridas nas características fisico-químicas dos solos sob alagamento foram devido ao consumo do oxigênio disponível no ambiente pelos microorganismos anaeróbicos e sistema radicular dos capins, o que ocasionou a elevação de temperatura do solo, aumento do pH e redução de Eh. 


\section{REFERÊNCIAS BIBLIOGRÁFICAS}

ALAM, S.M. Nutrient uptake by plants under stress condtions. In: PESSARAKLI, M (Ed.). Handbook of plant and crop stress. New York: Marcel Dekker, 1999. cap. 3. p. 287-293: Stress and its effects on nutrient uptake.

ALVARES, V. H. Enxofre. Viçosa: UFV, 1990. 100p. (Apostila de SOL-370 Química e fertilidade do solo).

ARMSTRONG, W.; BRÄNDLE, R.; JACKSON, M. B. Mecanisms of flood in plants. Acta Botanica Neerlandica, v. 43, p. 307-358, 1994.

ARREGOCÉS, O. P.; LEÓN, L. A. Fertilización nitrogenada del arroz. Cali, Colômbia: CIAT, 1982. 40 p.

ASSOCIATION OF OFFICIAL ANALYTICAL CHEMISTS. Official methods of analysis of AOAC international. 16.ed. Washington: Arlington, 1995. 2v.

BARROS, N. F. Nitrogênio. Viçosa: UFV, 1990. 100p. (Apostila de SOL-370 Química e fertilidade do solo).

BARTA, A. L. Regrowth and alcohol dehydrogenase activity in water logged alfafa and birdsfoot trefoil. Agronomy Journal, v. 72, n. 17, nov./dez. p. 1017-1020, 1980.

BARUCH, Z. Responses to drought and flooding in tropical forage grasses. Plant and Soil, v.164, p.97-105, 1994. 
BARUCH, Z.; MÉRIDA T. Effects of drought and flooding on root anatomy in four tropical forage grass. International Journal of Plant Science., v.156, n.4, p.514521, 1995.

BAtAglia, O. C.; FURLANI, A. M. C.; TEIXEIRA, J. P. F. et al. Métodos de análise química de plantas. Campinas: IAC, 1983. 48p. (IAC. Boletim Técnico, 78).

BOGDAN, A. V. Tropical pastures and fodder plants. Londres: Longman. 1977. 475p.

BORGES JÚNIOR, M. Calagem e disponibilidade de ferro e manganês para o arroz em solos inundados. Viçosa, 1997. 74p. Tese (Mestrado) - Universidade Federal de Viçosa.

BORKERT, C. M. Manganês. In: FERREIRA M. E. ; DA CRUZ M. C. P. (Ed.). Micronutrientes na agricultura. Piracicaba: Potafos/CNPQ, 1991. p.173-190.

BRADFORD, M. A rapid and sensitive method for the quantification of microgram quantities of protein utilizing the principle of protein dye binding. Journal of Analytical Biochemistry , v.72, p.248-258, 1976.

BRADY, N.C. Natureza e propriedade dos solos. Rio de Janeiro: Livraria Freitas Bastos, 1989. 898 p.

BUXTON, D.R.; FALES, S.L. Plant environment and quality. In: FAHEY JUNIOR, A. (Ed.), ASA, CSSA, SSSA. Wisconsin, USA. Forage quality, evaluation and utilization. Madison: 1994, 998 p.

CAMARÃO, A. P.; MARQUES, J.R.F. Gramíneas nativas de terra inundável do trópico úmido brasileiro. Belém: EMBRAPA-CPATU, 1995. 62p. (EMBRAPA-CPATU, documentos, 81). 
CAMARÃO, A. P.; SERRÃO, E. A.S.; MARQUES, J.R.F.; RODRIGUES FILHO, J.A. Avaliação de pastagens nativas de terra firme e inundável da região do baixo e médio Amazonas. Belém: EMBRAPA/CPATU, 1991. 21p. (EMBRAPA. PNP Avaliação de recursos naturais socioeconômicos do trópico úmido. Projeto 028.85.007/4).

CRAWFORD, R.M.M. Metabolic adaptations to anoxia. In: HOOK, D.D.; CRAWFORD, R.M.M (Ed.). Plant life in anaerobic environments. Michigan: Ann Arbor Science Publication, 1978. p. 119-136.

CRAWFORD, R.M.M. Oxygen availability as and ecological limit to plant distribution. Advances in Ecological Resourts, v.23, p.93-185, 1992.

DECHEN, A. R.; HAAG, H. P.; CARMELlO, Q. A. C. Diagnose visual. Micronutrientes na agricultura. Jaboticabal, 1991. Anais. Piracicaba: POTAFOS/CNPq, p. 273-288.

DIAS FILHO, M.B. Tolerance to flooding in five Brachiaria brizantha accsessions. Pesquisa Agropecuária Brasileira, v.37, n.4, p. 439-447, 2002.

DIAS FILHO, M. B.; CARVALHO, C.J.R. Physiological and morphological responses of Brachiaria spp. to flooding. Pesquisa Agropecuária Brasileira, v. 35, n. 10, p. 1959-1966, 2000.

DREW, M. C. Sensing soil oxygen. Plant cell environment, n. 13, p. 681-693, 1990.

DREW, M. C. Soil aeration and plant root metabolism. Soil Science, v.154, p. 259-268, 1992.

DREW, M. C.; JACKSON, M.B.; GIFFARD, S. Ethylene-promoted adventitious rooting and development of cortical air space (aerenchyma) in roots may be adaptive responses to flooding in Zea mays. Planta, n. 147, p. 83-88, 1979. 
EMPRESA BRASILEIRA DE PESQUISA AGROPECUÁRIA. Centro Nacional de Pesquisas de Solos. Sistema brasileiro de classificação de solos. Brasília, 1999. 412p.

GOERING, H.K.; VAN SOEST, P.J. Forage fiber analysis: apparatus, reagents, procedures and some applications. Washington: USDA, 1970. 20p. (USDA. Agriculture Handbook, 379).

GOMIDE, J.A. Mineral composition of grasses and tropical leguminous forages. In: LATIN AMERICAN SYMPOSIUM ON MINERAL NUTRITION RESEARCH WITH GRAZING RUMINANTS, Belo Horizonte, 1976. Proceedings. Gainesville: University of Florida, 1978. p.32-40.

GUIMARÃES, G. F. B. Avaliação de quatro forrageiras tropicais cultivadas em dois solos da Ilha de Marajó-Pa submetidos a crescentes saturações por bases. Piracicaba, 2000. 193p. Dissertação (Mestrado) - Escola Superior de Agricultura "Luiz de Queiroz”, Universidade de São Paulo.

HADDADE, I. R. Crescimento de espécies forrageiras tropicais submetidas a diferentes períodos de alagamento. (compact disc) In: REUNIÃO ANUAL da SOCIEDADE BRASILEIRA de ZOOTECNIA, Botucatu, 1998 Anais. Botucatu: SBZ, 1998.

HADDADE, I. R.; OBEID, J. A;. FONSECA, D. M.; PEREIRA, O. G.; SILVA, M. A. Crescimento de espécies forrageiras tropicais submetidas a diferentes períodos de alagamento. Revista Brasileira de Zootecnia, v. 31, n. 5, p. 1924-1930, 2002.

HEINRICHS, D.H. Root-zone temperature effects on flooding tolerance of legumes. Canadian Journal of Plant Science, v.52, p.985-990, 1972.

HOOK, D. D. Adaptation to flooding with fresh water. In: KOZLOWSKI, T. T. (Ed.) Flooding and plant growth. Madson: Wisconsin Academic Press, 1984. 356p. 
HUANG, B. Waterlogging responses and interaction with temperature, salinity and nutrients. In: WILKINSON, R. E (Ed.). Plant - environments interactions. New York: Marcel Dekker, 2000. cap. 8. p. 263-282.

HUANG, B. GRIFFIN, G. A. NESMITH, S. et al. Responses of squash to salinity, waterlogging, and subsequent drainage. I. gas exchange, water relations and nitrogen status. Journal of Plant Nutrition, v.18, p.127-140, 1995.

HUMPHREYS, L. R. Environmental adaptation of tropical pasture plants. London: McNillon, 1981. 261p.

INSTITUTO BRASILEIRO DE GEOGRAFIA E ESTATÍSTICA. Anuário Estatístico do Brasil. Rio de Janeiro : IBGE. v.56, p. 118-132, 1996.

ISHIDA, F. Y. Crescimento, trocas gasosas, fluorescência e assimilação de nitrogênio em plantas de Setaria anceps e Paspalum repens submetidas a inundação parcial e total. Lavras, 1998. 78p. Dissertação (Mestrado) - Universidade Federal de Lavras.

JACKSON, M.S. Regulation of aerechyma formation in roots and shoots by oxygen and ethylene. In: OSBORNE, D.J.; JACKSON, M.S. Cell separation in plants. Physiology, Biochemistry and Molecular Biology. Berlin: NATO ASI Series, v.H35, 1989, p.263-274.

JACKSON, M.S.; DREW, M.C. Effect of flooding on growth and metabolism of herbaceous plants. In: KOZLOWSKI, T. T. (Ed.). Flooding and plant growth. Madson: Wisconsin Academic Press, 1984, p.47-111.

JOHN, C.D.; GREENWAY, H. Alcoholic fermentation and activity of some enzymes in rice roots under anaerobiosis. Australian Journal of Plant Physiology, v. 3., p.325336, 1976. 
JOSHI, A. K. Genetic factors affecting abiotic stress tolerance in crops. In: PESSARAKLI, M (Ed.). Handbook of plant and crop stress. New York: Marcel Dekker, 1999. cap. 3. p. 800-803: Plant and crop responses under salt, drought, heat, temperature, light and other conditions.

KAMPF, N. O. Ferro no solo. In: REUNIÃO SOBRE FERRO NO SOLO, Goiânia, 1997. Anais. Goiânia: EMBRAPA-CNAF, 1988. p.56-72.

KARP, G. Cell and molecular biology. New York: John Wiley, 1996. 773p.

KOZLOWSKI, T.T. Responses of woody plants to flooding. In: KOZLOWSKI, T.T. (Ed.). Flooding and plant growth. New York: Academic Press, 1984. p. 129-163.

LARCHER, W. Ecofisiologia vegetal. 2 (Ed.) São Carlos: RIMA, 2000. 531p.

LÉON, L.A.; ARREGOCÉS, O. Química de los suelos inundados. Guia de estudios. Cali: Colombia, CIAT, 1981. 35p.

LIZASO, J.I.; RITCHIE, J.T. Maize shoot and root responses to root zone saturations during vegetative growth. Agronomy Journal, v.89, n. 1, p.125-134, 1997.

LUZ, P. H. C; VITTI, G. C.; CANTOS NETO, B. L.; SUGIMOTO, L. S. Nutrição de adubação de pastagens no Estado de São Paulo. Piracicaba. ESALQ, CNPq, FEALQ, GAPE, IAP, 2001. 70 p.

MELLO, J. W. V.; FONTES, M. P. F.; RIBEIRO, A. C. Inundação e calagem em solos de várzea. Alterações em pH, Eh e teores de $\mathrm{Fe} 2+$ e Mn2+ em solução. Revista Brasileira de Ciência do Solo, n. 16, p.309-317, 1992.

MENGEL, K.; KIRKBY, E.A. Principles of plant nutrition. 4. ed. Bern: International Potash Institute, 1987. 687p.

MITIDIERI, J. Manual de Gramíneas e leguminosas para pastos tropicais. 2.ed. São Paulo: Nobel, 1992, 198p. 
MORAES, M.G.; ALVES, J.D.; OLIVEIRA. L.E.M. efeitos da anerobiose induzida por alagemnto em plântulas de seis espécies herbáceas. Ciência e Agrotecnologia, v.25, n.4, p.941-951, 2001.

MORAES, J. F. M.; DYNIA, J. F. Alterações nas características químicas e físicoquímicas de um solo gley pouco húmico sob inundação e após a drenagem. Pesquisa Agropecuária Brasileira, v. 27, n. 2, p. 223-235, 1992.

NAIDOO, G.; NAIDOO, S. Waterlogging responses of Sporobulus virginicus (l.) Kinth. Oecologia, n.90, p. 445-450, 1992.

NASCIMENTO JUNIOR, D.; ROCHA, F.C. Fisiologia vegetal manejo das pastagens. http://fisiologia vegetal e manejo das pastagens.htm (27 jun. 2001).

OLIVEIRA, P. C. Avaliação de gramíneas cultivadas em três níveis de fertilidade do solo, visando a revegetação de áreas sujeitas a estresse hídrico. Lavras, 1994. Tese (Mestrado) - Universidade Federal de Lavras.

PEZESHKI, S.R. Wetland plant responses to soil flooding. Environmental and Experimental Botany, v. 46, p. 299-312, 2001.

PEZESHKI, S.R.; PARDUE, J.H.; DeLAUNE, R.D. Leaf gas exchange and growth of flood-tolerant and flood-sensitive tree species under low soil redox condition. Tree Physiology, v. 16, p. 453-458, 1996.

PIEDADE, M.T.F.; JUNK, W. J.; LONG, S. P. The Produtivity of the $\mathrm{C}_{4}$ Grass Echinochloa polystachya on the Amazon Floodplain. Ecology. v.72, n.4, p.14561463, Aug., 1991.

PLATZECK, C. O. Efeito do estresse hídrico sobre o estabelecimento de Brachiaria humidicola e Setária anceps cv. Kazungula. Piracicaba, 1989. 97 p. Dissertação (Mestrado) - Escola Superior de Agricultura “Luiz de Queiroz”, Universidade de São Paulo. 
PONNAMPERUMA, F. N. Effects of flooding on soils. In: KOZLOWSKI, T. T. Flooding and plant growth. Madson: Wisconsin Academic Press, 1984. 356p.

PONNAMPERUMA, F. N. The chemistry of submerged soils. Advances of Agronomy, v.24, p. 29-96, 1972.

PRADO C, H. B. A.; de MORAES, J. P. A. P. V. Photosynthetic capacity and specific leaf mass in twenty woody species of cerrado vegetation under field conditions. Photosynthetica, v. 33, p. 103-112, 1997.

PUPO, N. I. H. Manual de Pastagens e Forrageiras. Campinas: Instituto Campineiro de Ensino Agrícola, 1979. 344p.

RAIJ, B. V. Fertilidade do solo e Adubação. Piracicaba: Associação Brasileira para Pesquisa da Potasssa e do Fosfato, 1991. 343p.

REGEHR, D.L.; BAZZAZ, F.A.; BOGGESS, W.R. Photosynthesis, transpirations, and leaf conductance of Populus deltóides in relation to flooding and drought. Photosynthetica, n.9, p.52-61, 1975.

REIS, R. A.; RODRIGUES, L. R. A. Valor nutritivo de plantas forrageiras. Jaboticabal: FCAVJ/UNESP, 1993. 26p.

SACHS, M.M.; SUBBAIAH,C.C.; SAAB, I.N. Anaerobic gene expresión and flooding tolerance in maize. Journal of Experimental Botany, v.47, p.1-15.1996.

SANCHEZ, P. Properties and management of soils in the tropics. In: KOZLOWSKI, T. T. (Ed.) Flooding and plant growth. Madson: Wisconsin Academic Press, 1984. 356p.

SARRUGE, J. R.; HAAG, H. P. Análises químicas em plantas. Piracicaba: Livroceres, 1974. 55p.

SAS INSTITUTE. SAS users guide: statistics; release version 6. Cary, 1998. 1028p. 
SEIFFERT, N. F. Gramíneas forrageiras do gênero Brachiaria. Campo Grande: EMBRAPA-CNPGC, 1984. 74p.

SKERMAN, P. J.; RIVEIROS; F. Tropical grasses. Roma: FAO, 1990. 832p.

SOARES FILHO, C. V. Recomendação de espécies e variedades de Brachiaria para diferentes condições. In: SIMPÓSIO SOBRE MANEJO DA PASTAGEM, 11., Piracicaba, 1994. Anais. Piracicaba: FEALQ, 1994. p. 25-48.

SOJKA, R. E. Stomatal closure in oxygen stressed plants. Soil science, v.154, n. 4, p. $269-280,1992$.

TRIBUZY, E. S. Metabolismo do carbono e nitrogênio em plantas de ingá (Inga vera Willd.) submetidas a diferentes alturas e tempos de submersão. Lavras, 1998. 64p. Dissertação (Mestrado) - Universidade Federal de Lavras.

VARTAPETIAN, B. D.; ANDREEVA, I. N.; KOSLOVA. G. I. et al. Mitochondrial ultrastructure in roots of mesophyte and hydrophyte at anoxia and after glucose feeding. Protoplasma, n. 91, p. 243-256, 1977.

VITTI, G.C.; NOVAES, N.J. Adubação com enxofre. In: MATTOS, H.B. (Ed.). Calagem e adubação de pastagens. Piracicaba: Associação Brasileira para Pesquisa da Potassa e do Fosfato, 1986. p.191-231.

VITTORI, A. Produção de matéria seca de gramíneas tropicais. (compact disc) In: REUNIÃO ANUAL da SOCIEDADE BRASILEIRA de ZOOTECNIA, Botucatu, 1998 Anais. Botucatu: SBZ, 1998.

WERNER, J. C.; MONTEIRO, F. A. Enxofre e micronutrientes na agricultura brasileira. In: REUNIÃO BRASILEIRA DE FERTILIDADE DO SOLO, 17., Londrina, 1988. Anais. Londrina: EMBRAPA, CNPS,IAPAR, 1988. p. 87-102.

WILDIN, J. H. Echinochloa polystachya (H.B.K) Hitchcock (aleman grass) cv. Amity. Australian Journal of Experimental Agriculture, v.29, n.2, p. 294. 1989. 